Portland State University

PDXScholar

\title{
An Investigation of the Relationship Between Turnover of Incumbent Board Members and Turnover of the District's Superintendent
}

Frederick James Loomis

Portland State University

Follow this and additional works at: https://pdxscholar.library.pdx.edu/open_access_etds

Part of the Other Educational Administration and Supervision Commons Let us know how access to this document benefits you.

\section{Recommended Citation}

Loomis, Frederick James, "An Investigation of the Relationship Between Turnover of Incumbent Board Members and Turnover of the District's Superintendent" (1995). Dissertations and Theses. Paper 1390. https://doi.org/10.15760/etd.1389

This Dissertation is brought to you for free and open access. It has been accepted for inclusion in Dissertations and Theses by an authorized administrator of PDXScholar. Please contact us if we can make this document more accessible: pdxscholar@pdx.edu. 
AN INVESTIGATION OF THE RELATIONSHIP BETWEEN TURNOVER OF INCUMBENT BOARD MEMBERS AND TURNOVER OF

THE DISTRICT'S SUPERINTENDENT

\author{
by \\ FREDERICK JAMES LOOMIS
}

A dissertation submitted in partial fulfillment of the requirements for the degree of

\author{
DOCTOR OF EDUCATION \\ in \\ EDUCATIONAL LEADERSHIP: \\ ADMINISTRATION AND SUPERVISION
}

Portland State University

- 1995 
UMI Number : 9530966

Copyright 1995 by

Loomis, Frederick James

All rights reserved.

UMI Microform 9530966

Copyright 1995, by UMI Company. All rights reserved.

This microform edition is protected against unauthorized copying under Title 17, United States Code.

\section{UMI}

300 North Zeeb Road

Ann Arbor, MI 48103 


\section{DISSERTATION APPROVAL}

The abstract and dissertation of Frederick James Loomis for the Doctor of Education in Educational Leadership:

Administration and Supervision were presented April 13, 1995, and accepted by the dissertation committee and the doctoral program.

\section{COMMITTEE APPROVALS:}
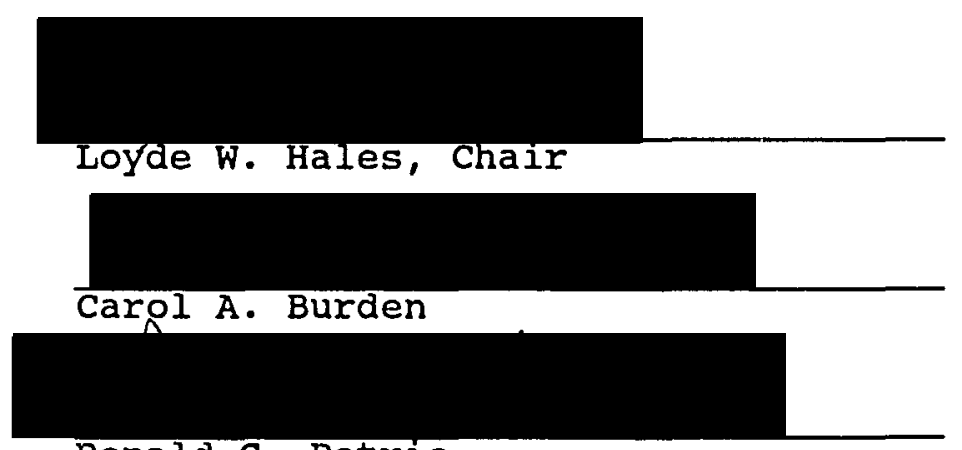

Ronald G. Petrie

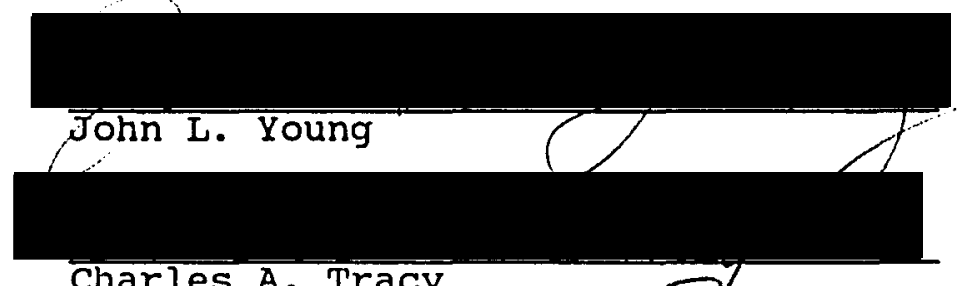

Charles A. Tracy

Representative of the office of Graduate studies

DOCTORAL PROGRAM APPROVAL:

Robert B. Everhart, Dean

School of Education

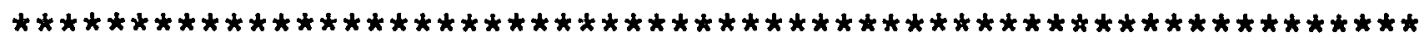

ACCEPTED FOR PORTLAND STATE UNIVERSITY BY THE LIBRARY

by

on 12 ene 1895 
ABSTRACT

An abstract of the dissertation of Frederick James Loomis for the Doctor of Education in Educational Leadership: Administration and Supervision April 13, 1995.

Title: An Investigation of the Relationship Between Turnover of Incumbent Board Members and Turnover of the District's superintendent

The purpose of this study was to investigate the relationship between the turnover of incumbent board members and turnover of the district's superintendent. Research questions asked were:

1. What are the turnover rates within five years for: a. superintendents?

b. incumbent board members?

c. superintendents when an incumbent board member fails to be reelected?

2. What are the factors associated with board member turnover?

3. What are the factors associated with superintendent turnover?

4. Are there variables which may be used together to discriminate between categories of superintendent turnover? 
5. What is the relationship between district size and number of schools in the district to superintendent and board member turnover?

6. What is the relationship of geographic location of the districts to superintendent and board member turnover?

7. What is the relationship of the type of district, elementary, high school, or union high school, to superintendent and board member turnover?

A questionnaire was sent to the superintendents of all school districts in oregon governed by five-member school boards. The results obtained from the questionnaire were analyzed using frequency distributions, percentages, means, standard deviations, and content analysis. All hypotheses were tested at the .05 level of significance.

The following conclusions were based upon the data collected and analyzed in the study. The total number of elections impacted both board member and superintendent longevity. The total number of changes on the board dramatically affected superintendent longevity. The superintendent's relationship with the board did not affect superintendent turnover until the political climate in the district became active. Political climate played a crucial role in both superintendent and board member turnover.

Recommendations for further research include: (a) an in-depth study of what constitutes a contested election, (b) a study of the differences between large and small school 
districts that may impact superintendent and board member turnover is recommended, (c) a study of the role of the board chair in superintendent turnover, and (d) a study of the difference in superintendent turnover between superintendents who also serve as principals and those who do not. 


\section{ACKNOWLEDGEMENTS}

I wish to express gratitude to Dr. Loyde Hales, chairman of my doctoral committee, and to the other members of the committee who also gave consistently of their time and support: Dr. John Young, Dr. Carol Burden, Dr. Ronald Petrie, and Dr. Carl Tracy.

A special and deep thanks to Dr. Jack Lind who mentored me through the initial process. Dr. Tom Owen, Washington Educational Service District, is also recognized for his continuing support with the statistical portions of this dissertation.

Appreciation is also expressed to Dr. R. L. Rose and the staff of the Confederation of Oregon School Administrators and to Dr. Chris Dudley and the staff of the Oregon School Boards' Association, without whose assistance and cooperation this study would have been impossible.

I would like to thank the members of the Board of Directors, Washington/Yamhill County School District 511J, Gaston, for their cooperation in my work. I am most grateful to the staff of that school district for putting up with those times when the study may have distracted me from giving them the attention they deserve. Their loyalty to me in those times is very much appreciated. 
Finally I should like to thank my family and Kristine Harris without whose continuous support, both physical and mental, this project would not have been completed. 
TABLE OF CONTENTS

PAGE

ACKNOWLEDGEMENTS. • . . . . . . . . . . . . . . . ii

LIST OF TABLES. . . . . . . . . . . . . . . . . . . . viii

IIST OF FIGURES • • • • • • • . • • • • • • • • • • . • xi

CHAPTER

I INTRODUCTION . . . . . . . . . . . . 1

Background of the Problem. . . . . . 1

statement of the Problem . . . . . 6

Delimitation . . . . . . . . . . 7

Importance of the study. . . . . . . 9

Summary. . . . . . . . . . . . 11

Organization of the Study. . . . . . 11

Chapter II, Review of the

Literature

Chapter III, Methodology

Chapter IV, Results

Chapter V, Summary and

Conclusions

II REVIEW OF THE LITERATURE . . . . . . . . 13

Relationships. . . . . . . . . . 14

Relationship with the Board

Relationship with the staff

Relationship with Members of

the Community

Community. . . . . . . . . . . . 21

Problems Across Districts. . . . . . 25 
Finances

Curriculum/Demographics

Administration/Leadership

Contract

Incumbent Defeat and Involuntary

Turnover of the Superintendent . . . 35

Summary. •. . . . . . . . . 39

III METHODOLOGY. . . . . . . . . . . . 41

Design . . . . . . . . . . . 4 41

Sample . . . . . . . . . . . . . 43

Instrumentation. . . . . . . . . 45

Questionnaire

Publications

Data Collection Procedures... . . 48

Analysis . . . . . . . . . . 50

IV PRESENTATION, ANALYSIS AND DISCUSSION OF

DATA • . . . . . . . . . . . . . 52

Introduction . . . . . . . . . . 52

District Characteristics . . . . . 54

Size

Geographic Location

Demographic Zones

District Type

District Problems

Ballot Measure \#5

Current Problems Faced by School Districts

Difficulties Perceived by

Superintendents in Working

with Their Boards

Current Superintendents. . . . . . 64

Length of Service

Previous Experience

Job Satisfaction

Turnover Rate. . . . . . . . . . 72 
Board Member Turnover. . . . . . . . 74

The Law and Board Member openings Frequency of Turnover

Factors Associated with Board Member

Turnover . . . . . . . . . . 78

Changes in Board Membership and Superintendent Turnover

Board Relationship with the superintendent

Political Climate and Board Membex Turnover

Factors Related to superintendent

Turnover . . . . . . . . . . 89

Changes in Board Membership Relationship with the Board Political climate

Bond Attempts

Discriminate Analysis of Variables and Superintendent Turnover. . . . 105

Univariate Analysis

Discriminant Analysis

The Relationship of District size and the Number of Schools in the District to Superintendent and Board Turnover . 114

Size and Superintendent Turnover

District Size and Board Member

Turnover

The Relationship of Geographic Location and Superintendent/Board Member Turnover. . . . . . . . . 119

Geographic Location and Superintendent Turnover Geographic Location and Board Member Turnover

School District Type . . . . . . . 121

Type of District and Superintendent Turnover

District Type and Board Member Turnover 
vii

V SUMMARY, CONCLUSTONS, AND RECOMMENDATIONS. - 124

Summary. •. . . . . . . . . . . . 124

Purpose

Procedure

Results

Conclusions. . . . . . . . . . 133

Longevity of Superintendents

Board Mernber Longevity

Interdependience

Recommendations for Further Research . .' 141

REFERENCES. . . . . . . . . . . . . 145

APPENDICES

A QUESTIONNAIRE. • . • . • • . • • . . 153

B LETTERS OF SUPPORT . . . . . . . . . 158

C LIST OF DISTRICTS|. . . . . . . . . . 161 


\section{LIST OF TABIES}

TABLE

PAGE

1. Number of Teachers and students. . . . . . 55

2. District Type. . . . . . . . . . 60

3. Impact of Measure 5 on Superintendent Board Relationships. . . . . . . . . 62

4. Current Superintendent Perception of Problems Faced by School Districts . . . 63

5. Difficulties Perceived by Superintendents in Working with Their School Boards. . . 64

6. Number of Months in office of current superintendents. . . . . . . . . 66

7. Measure of Frequency and Percentage of Previous Position. . . . . . . . . 67

8. Frequency and Percentage of Previous Position and Satisfaction with Current Position as Superintendent. . . . . . 68

9. Superintendent Satisfaction and Board Member Years of Service. . . . . . 70

10. Measure of Frequency and Percentage for Interim Superintendents. . . . . . . 70

11. Measure of the Number of Months of Interim superintendency. . . . . . . . . 71

12. Turnover Rate. . . . . . . . . 73

13. Frequency of Board Member Openings . . . . 76

14. Years of Service for Board Members . . . . 77

15. Changes in Board Membership. . . . . . . 78

16. Reasons for Board Member Turnover. . . . . 79 
17. Frequency of Board Member Elections and Superintendent $\mid$ Turnover. . . . . . . . .

18. Frequency of Elections and Board Relationship with the superintendent . . 84

19. Frequency of Elections and Board opposition to the superintendent . . . . 85

20. Board Turnover and Political climate . . . 86

21. Frequency of Board Flections and Political climate. . . . . . . . . . . . 87

22. Board Member Turnover, Board Opposition, and Political climate. . . . . . . . . 88

23. Contested Elections and Superintendent Turnover . . . . . . . . . . . . 91

24. Changes in Board Membership and Superintendent Turnover. . . . . . . 93

25. Disposition of Superintendents Leaving the District . . . . . . . . . . . . 94

26. Predecessor Relationship with the Board of Directors and Superintendent Turnover . . . . . . . . . . . 95

27. Opposition on the Board of Directors and Superintendent Turnover. . . . . . . 97

28. Political climate and Superintendent Turnover . . . . . . . . . . . . 98

29. Political climate and Board opposition to the superintendent. . . . . . . 99

30. Political climate and Board Relationship to the Superintendent. . . . . . . . 102

31. Superintendent Turnover, Board Opposition, and Political climate. . . . . . . 103

32. Bond Attempts and Political climate of Districts. . . . . . . . . . . . 104

33. Analysis of Corollaries of superintendent Turnover ... ............ 108 
34. Standardized Discriminant Function Coefficients for Selected Variables and Superintendent Turnover. . . . . . . . 110

35. Classification of Results of Discriminant Analysis of Selected Variables and Superintendent Turnover. . . . . . . . 111

36. Standardized Discriminant Function Coefficients for Selected Variables and Superintendent Turnover, Five Variables. . 112

37. Classification Results of Discriminant Analysis of Selected Variables and Superintendent Turnover, Five Variables.

38. Classification of Results of Discriminant Analysis of selected Variables and Superintendent Turnover, Five Variables. . 113

39. Number of Schools and Superintendent Turnover . . . . . . . . . . . 115

40. Number of Teachers and superintendent Turnover . . . . . . . . . . . 116

41. Number of Schools and Board Member Turnover ............... 118

42. Number of Teachers and Board Member Turnover . . . . . . . . . . . . 118

43. Geographic Location and Superintendent Turnover .............. 120

44. Geographic Location and Board Member Turnover . . . . . . . . . . . . 120

45. Tupe of School District and superintendent Turnover . . . . . . . . . . . . 122

46. School District Type and Board Member Turnover . . . . . . . . . . . . . 


\section{LIST OF FIGURES}

FIGURE

PAGE

1. Map of oregon. . . . . . . . . . 59 
CHAPTER I

INTRODUCTION

Background of the Problem

School boards are groups of citizens who are elected to their positions on the school board. The Board, as an entity, is charged with the management of the school district from which it has been elected. Since there is no remuneration for serving on a school board in oregon, board members appoint a manager to carry out their directives. This manager is called by a variety of terms, superintendent, chief executive officer, or clerk. The terms are synonymous. In oregon, clerk is the legal terim, however superintendent is the term most commonly used to denote the chief executive officer in a school district.। It is the superintendent with whom most patrons come in contact. These contacts are normally a result of the role the superintendent assumes in carrying out the directives of the district's school board. It is therefore logical that the chief executive officer is inevitably recognized as the person charged with the manipulation and exercise of the district's power. In combination, this creates an image of the superintendent as "the district" (Hess, 1968). 
Superintendents face a great many problems today. Perhaps, the "biggest" of which is the spread of property tax limitation measures. While, as chief administrator the superintendent has always been concerned with school finances, the property tax limit has exacerbated the problem. Special interest groups and community politics have continued to exercise pressure on the school district to provide for their special needs while funding is being limited.

Walden conducted a study in 1966 in which he hypothesized that there is a positive correlation between community demographics and "involuntary superintendent turnover." Walden's study revealed significantly more turnover in the office of superintendent after school board elections in which incumbent board members were defeated for reelection than in those situations where incumbents were successful in their reelection attempts.

When turnover occurs in the office of superintendent, involuntary turnover will be significantly higher when there has been a change in the composition of the school board within the previous three years than when the board has not undergone change during that period. (p. 2)

To test his hypothesis, Walden (1966) surveyed 117 southern California school districts. He limited his study to those districts which had not undergone recent boundary adjustments, but which had five-member school boards. In districts where the chief executive officer was replaced, a questionnaire was used to determine the cause of that 
turnover. The result of the questionnaire was that walden discovered a "significant relationship" existed between the two factors.

Walden (1966, p. 145) discovered that superintendents were replaced when incumbent board members failed in attempts to be reelected. He divided his findings into three general categories: (a) incumbents were defeated due to existing political instability in the district at the time of election; (b) it appeared impossible for superintendents to divorce themselves from the old power structure as represented by incumbent board members; and (c) since the superintendent was associated with the "old" power structure, there was a corresponding lack of support for him/her in the new board.

Arnez (1981) stated, in The Besieged School

Superintendent, that:

superintendent board relationships are dynamic and complex and therefore cannot be examined in the light of a single factor due to the many independent influential factors involved. (p. 85) Blumberg and Blumberg (1985), on the other hand, made a point of stating that politics is the critical factor in superintendent survival. There is an obvious discrepancy in the field of study as to exactly what can cause involuntary turnover in the office of the superintendent.

Property taxes are used to support public schools in most states. The late 1980s and early 1990s have seen a property tax revolt by taxpayers. Telephone conversations 
in 1992, by the researcher, with the oregon School Boards Association (OSBA), disclosed that in states where tax rates and/or school budgets are subject to district voter approval, many districts have encountered severe financial problems. Two of the most western continental states have passed property tax limitation measures (California Proposition 13, 1973; Oregon Ballot Measure \#5, 1990). During the last decade school districts in most states have encountered financial difficulties as a result of state and/or local recession. Downey, Bushweller, and Zakariya (1994, p. 18), writing in The American School Board Journal, confirmed that money is the number one concern among board members across the nation. Clearly, school districts are now under additional financial constraints.

Discussions with OSBA and the confederation of oregon School Administrators (COSA) suggest that the longevity in the office of superintendent has decreased to less than three years in a district. A significant percentage (28\%) of current superintendents believe that they have little or no job security in their present positions (Downey et al., 1994, p. 21). Fewer and fewer school board members are standing for election as incumbents. According to OSBA, those board members who do stand for reelection are regularly defeated. It should be noted that neither organization mentioned above has gathered statewide data relevant to the turnover of superintendents nor board 
members. Their data appear to have an experiential and/or observational basis.

Conditions in California in 1966, during the walden (1966, p. 24) study, appeared to have been similar to those currently in oregon, in that, as political pressure and financial pressure increase, the longevity of both the superintendent and of board members is impacted.

The turnover rate for superintendents is relatively high and expected to increase as a result of increasing financial pressures on school districts and the resultant increase in proactive political climates surrounding schools. The cost in recruiting a superintendent is high, both in dollar expenditure and in the time used by the board and district staff. During superintendent transition, management and leadership in the district are likely to be lessened. The obvious result is that district patrons will become more active in the politics of the district, filling the temporary void left during the search for and the hiring of a new superintendent. A cycle is created, consisting of the heightened political activity, failure of incumbent board members to be reelected, the dismissal of the superintendent, and back to heightened patron political activity. Few studies have been conducted concerning the factors related to either superintendent or board member turnover, and even fewer have focused on the relationship with the changing political atmosphere, superintendent 
longevity, and school board member turnover. The time seems appropriate to examine the effects of changing political conditions on the longevity of the school district chief executive officers and the school boards which employ them.

\section{Statement of the Problem}

In Oregon, with its traditional reliance on property taxes to support its system of public education and the continual challenges to that system, politics appear important, if not critical, to the survival of the superintendent. School finance has placed a significant strain on the leadership in those districts facing financial crises. As the five-year impact of oregon Ballot Measure \#5 (1990) draws to a conclusion, few if any, of the oregon districts will remain untouched by financial crises. Board members are no longer, as a matter of course, standing for or being elected. Superintendents are being replaced. The political and financial climates in oregon are likely to contribute to increased stress on the superintendency and among board members.

The primary purpose of this study was to determine if there is a relationship between political crises in a school districr, as indicated by incumbent board member turnover, and the involuntary replacement of that district's chief executive officer.

Specifically, in this study these questions were asked: 
1. What are the turnover rates within five years for:

a. superintendent?

b. incumbent board members?

c. superintendents when an incumbent board member fails to be reelected?

2. What are the factors associated with board member turnover?

3. What are the factors associated with superintendent turnover?

4. Are there variables which may be used together to discriminate between categories of superintendent turnover?

5. What is the relationship of district size and number of schools in the district to superintendent and board member turnover?

6. What is the relationship of the geographic location of the districts to superintendent and board member turnover?

7. What is the relationship of the type of district (elementary, high school, or union high school) to superintendent and board member turnover?

\section{Delimitation}

This study was limited to the state of oregon and to districts within the state with five-member boards. The research disclosed that the largest districts in the state are governed by boards with more than five board members. 
This disclosure meant that the largest districts in oregon were eliminated from the study and that those districts included were, in general, smaller rural and/or suburban districts.

As with some other states, oregon has adopted a property limitation law (Oregon Ballat Measure \#5, 1990). This law was implemented just before the study began, and will not fully impact districts until 1996. The law severely limits a district's ability to gain financial support from its patrons by ultimately reducing the amount of tax levied for schools to $\$ 5$ per $\$ 1,000$ of property value. The tax limitation law is a special circumstance that oregon school districts must face. Further, the oregon Educational Act for the 21 st Century (1991) will change the state's mandated curriculum by the year 2000. Among other items, this act mandated longer days, a longer school year, and outcome based education for students. Finally, oregon adopted a school district Consolidation Law (cited in oregon Department of Education, 1991) which mandated that all elementary districts consolidate with the union high school districts to which they send their high school students, by the year 1996. This law will eliminate elementary districts in oregon. The impact of this legislation is two-fold: (a) the implementation of these laws will require funds that are not currently available, and (b) the change in curricular structure is not uniformly popular throughout the state. 
School administration and boards of directors will be challenged in the next few years to meet both the wishes of their patrons and those of the state.

\section{Importance of the study}

Webster defined "politics" as "the art and science of government . . dealing with the regulation and control of men living in society" (Grove, 1966, p. 1,755). When asked to list those institutions considered political the reader would surely omit police, fire and school services from that list. The school district patron seldom, if ever, recognizes the board of education's role in establishing rules or laws, called policies, which do in fact control the members of the district's society. It is only recently that schools have been recognized as having a political basis. Such a realization is fundamental to this study. Communities are seeing their local schools as forums. They envision the school as reflecting their community values and morays. It is the school which will train tomorrow's community members. "It seems apparent that the community, in an effort to perpetuate itself, will look to the school as much as to any element of society to protect the status quo" (Zeigler, Kehoe, \& Reisman, 1985, p. 103). with the advent of property tax limitations, requirements for new curricula, and increasing enrollments, the pressure on school boards to provide for the community's 
needs has increased. Since it is the superintendent with whom most patrons come in contact, certainly on a more frequent basis than a patron might meet formally or informally with the district board of directors, being the chief executive officer is inevitably recognized as being the person charged with the manipulation and exercise of the district's power. This creates an image of the superintendent as "the district" (Hess, 1986). The superintendent deals with the control of others through| the district's power. Control of others through power is utilization of political power; this is the role of a politician (Blumberg \& Blumberg, 1985).

This study deals with the outcome of having the superintendent recognized as wielding the power of the district and of being a political officer. As board members are replaced, the power structure of the board shifts. When an incumbent member is defeated, it is assumed that the power structure is more greatly disrupted than when a non incumbent is elected without facing an incumbent. A change in philosophy and power should become more apparent after an incumbent defeat as it is possible for a non incumbent who is elected to represent a continuation of the current power structure. Since the superintendent represents the current power structure, a shifting in power represented by an incumbent defeat should affect the superintendency. That 
effect may be seen in the loss or retention of the superintendent's position in the district.

Summary

This study examines the effect that there is on the longevity of the superintendent when incumbent board members are defeated. It studies the effect that recent legislation in oregon had on school boards and superintendents.

$$
\text { organization of the study }
$$

This study is divided into four remaining sections: review of the literature, methodology and instrumentation, results, and summary and conclusions. A brief description of each section follows.

\section{Chapter II, Review of the} Literature

Chapter II presents a summary of the literature discussing the causes for superintendent turnover. The chapter is divided into five subsections with emphasis on the last area, incumbent defeat and superintendent replacement. The subsections included in Chapter II are:

1. Superintendent relationships.

2. The community.

3. Problems common across districts.

4. The board of directors.

5. Incumbent defeat. 
Chapter III, Methodology

Chapter III presents the methodology used in this study. It discusses the development and use of the questionnaire given to gather data for this study. Terms used in this study are defined in this chapter.

Chapter IV, Results

Chapter IV presents the results of the study. Appropriate statistical analysis used are explained and graphically represented. Reliability and validity are discussed.

Chapter V, summary and Conclusions

Chapter V discusses the end result of the study and gives possible areas for further exploration. 
CHAPTER II

REVIEW OF THE LITERATURE

This chapter presents a review and summary of the literature discussing the causes for superintendent turnover. There appears to be a natural division of the Iiterature into five major areas related to superintendent turnover. These areas are:

1. Superintendent Relationships

2. The Community

3. Problems Common Across Districts

4. The Board of Directors

5. Incumbent Defeat

This review discusses the literature relating to each area and its impact in creating a situation leading to involuntary turnover in the office of the chief executive officer. The final section of this chapter turns its attention to the literature that speaks directly to the defeat of incumbent board members and the effect that their defeat may have on the longevity of the chief executive officer. This section closely relates to the purpose of this study, which was to examine the factors related to the longevity of chief executive officers and members of their boards. 
Relationships

The superintendents, in the exercise of their office, must be cognizant of the connection existing between the superintendent, the school board, the district's staff, and the members of the community. These relationships, while labeled with educational terminology, are not specific to school district management. All corporate chief executive officers need to be aware of their relationship to their boards, employees, and customers and the impact these relationships have on chief executive officers' ability to lead and direct their district (Blumberg, 1989, p. 54). Haugland (1987) studied the rank order difference in the perceived importance of these relationships between board members and the superintendent. He found that differences existed in the perceived importance placed on the relationships between the board and the superintendent. The board placed "personnel management" first while the superintendent placed "board relationship" first. Both parties, however, agreed that the relationship that the superintendent has with the board, staff, and community is critical to the renewal of the superintendent.

\section{Relationship with the Board}

It is obvious that there must be a relationship between the employee and the employer. The relationship between the superintendent and the board is that of an employee with his 
or her employer. This "business relationship" is often overlooked when the relationship between the superintendent and the board is under study. The superintendent and the board share the responsibility for establishing a relationship that is open, honest, and trusting (Colorado Association of School Executives, 1982). Hess (1986), writing in The School Administrator, stated that the circumstances surrounding the dismissal of a superintendent remain a much neglected subject; however, the cause (Hess believed that no one is fired without cause) relates to management or governance skills rather than to technical skill. "Governance" is defined in Hess' work as working effectively with governing bodies by sharing a respect for the "formal roles" of each party. This mutual respect will be displayed throughout the board/superintendent relationship, even when dismissal becomes the chosen option. He concludes that, when the board feels that dismissal is the option they wish to exercise, the superintendent will agree. If the various formal roles have been established and maintained throughout the relationship, the superintendent will conclude that it is time to "move on" and all parties can agree to conduct the dismissal privately, with little trauma to each.

The theme of "formal relationship" between the board of directors and its chief executive officer is one that pervades the literature. Hess contends that the 
relationship, while not always able to provide total job security, would always protect the dignity of the individuals involved. The vehicle for providing for the initial steps in ensuring some formality in the relationship between the board and the superintendent is the superintendent's contract. Usually the contract is the first project that the board and superintendent work on mutually. The contract project can establish both the formal and informal roles of the board/superintendent relationship. Greenwood and Zirkel (1990) and Chand (1984) supported Hess (1986) in the statement that strong contracts between school boards and superintendents protect both parties when dismissal and/or non-renewal are immanent. The case of Joseph Brzenski is illustrative of this concept (cited in Zakariya, 1984). Brzenski was the superintendent of the Denver Schools from 1977 until he was dismissed in 1984 for failure to "get along with the board." In researching this case, Zakariya discovered that some members of the board had taken office with a predisposed philosophyl and that Brzenski was unable to establish with them the formal role he had established with members of preceding boards. This lack of a formal relationship resulted in the dismissal of the superintendent. Zakariya used this case, and others, to further refine the "formal roles" concept. She believed that a key element of the board/superintendent relationship is communication. She 
stated that, in the cases studied, philosophical differences and/or personality clashes lead to missing or ineffectual communications that ultimately lead to employment problems for the superintendent.

Communications between the superintendent and the board of directors are discussed extensively in the literature on the superintendent's relations with the board, the staff, and the community (Chance \& Capps, 1990; Chand, 1984).

Blumberg and Blumberg (1985) felt that communications are essential to the maintenance of the board/superintendent relationship. He stated that this contact must be maintained for several reasons; it is the methodology by which the board may support emotionally and politically its chief executive officer while showing the public that the board is, in fact, in control and not a "rubber stamp." Open communication with the board will assist the superintendent in two ways: (a) it will give the chief executive officer insight into how much support there is on the board for a particular project, and (b) it may allow the superintendent to modify his/her position before that position becomes public.

\section{Relationship with the staff}

The superintendent's relationship to the staff appears to be self-evident in that the superintendent must be allowed to behave in ways that permit him/her to have a continuing productive impact on the system. Perhaps that 
element most critical in enabling the superintendent to fulfill this role is the relationship he/she enjoys with the district staff. Without staff support, the superintendent can implement little. The community and board members share informative sources. For the public, information concerning their schools comes from members of the community, their neighbors. Many districts have policies requiring district employees, both licensed and non-licensed, to reside within the boundaries of the district. (For example, in oregon, Roseburg and Sweethome school districts have formal policies requiring their employees to live inside the districts' boundaries.) Since district employees are also neighbors, and since many patrons believe the district's employees to be experts concerning the local district, any lack of relationship and corresponding support between the staff and the superintendent will soon become known to the community and will impact the superintendent's effectiveness (Lutz, 1982, p. 11). Studies have shown that the turnover rate for the chief executive officers in larger districts is greater than those in smaller districts (Giles \& Douglas, 1990). This is logical, as it is more difficult to establish positive relationships with a large, and therefore more diverse, group than it is to do so with a smaller number of people. However, as Heim and Wilson pointed out in their 1987 study, relations with the staff were an important factor in smaller districts where there was high 
superintendent turnover. Both examples support the importance of positive staff relationships.

Caldwell and sites (1983) conducted a study of Pennsylvania school districts in a period shortly after the state passed a law allowing teachers to strike. They found that during a four-year period there were 35 strikes in the state; among the same 35 districts there were 17 superintendent firings. Only one district of those studied had a labor stoppage after "key administrative personnel" were replaced (p. 56). These findings indicate that, where the relationship between the chief executive officer and the staff is problematic, the chief executive officer becomes ineffective and is likely to be dismissed. The fact that teachers can be popular in their respective communities cannot be doubted. Grady (1992) conducted a study in a Nebraska school district where a "longtime teacher" was terminated. Community unrest and recall threats toward board members followed. The result of this action was the resignation of the superintendent.

It is certain that the staff has power in its own right. As a practicing superintendent, I have found that, when the staff is supportive of a concept, the concept is successful; whereas, when the staff is not supportive, the reverse becomes the case.

How can the chief executive officer maintain effectiveness while nurturing positive staff relationships? 
The literature indicates that the same themes employed in avoiding serious conflict with the board are also effective in staff relationships. The superintendent must maintain the role as "educational statesman" (Blumberg, 1989, p. 49). The superintendent must be accessible to the staff and must be open, honest, and trusting in all relations with the staff, particularly during times of conflict or potential conflict (Colorado Association of School Executives, 1982, p. 25). These concepts are further supported by studies conducted in Kansas, Nebraska, and South Dakota in which the relationship between the chief executive officer and his/her staff is seen as critical to the superintendent's abilities to perform and to remain in office (Grady, 1992; Haughland, 1987; Heim \& Wilson, 1987). Openness and honesty are elemental to communication and therefore to fail to communicate with the district staff is to court disaster.

\section{Relationship with Members of} the community

The superintendent must maintain a relationship with the district's patrons, the community. The literature establishes that the staff and the board are clearly members of the educational community (Caldwell \& Sites, 1983). It is logical to assume that those characteristics and behaviors that are effective in dealing with the staff and board will also serve the superintendent well in his/her relationship with the entire educational community. There 
is, however, an additional element in the superintendency that may not be particularly critical with other members of the school community; that element is visibility (Blumberg \& Blumberg, 1985, p. 49). The community pays for professional leadership, but leadership is often intangible. The community feels that it has the right to see the leadership for which it has paid. Leadership cannot be seen, what may be seen is the leader him or herself. The community, therefore sees the person of the leader as a form of leadership. The chief executive officer must be visible-must be where the educational community is. The same logic implies that being visible will allow the superintendent an amount of approachability. Visibility and approachability are used synonymously throughout the literature (Arnez, 1981, p. 85).

\title{
Community
}

\begin{abstract}
All communities have a system of power relationships within them. Power defined, in the literature and for the purposes of this paper, as the ability or authority to control others. (Walden, 1966, pp. 15-16)
\end{abstract}

Iannaccone and Lutz (1970) purported the "dissatisfaction theory of American democracy" that stated that citizens do not become politically active until a high level of dissatisfaction is felt. The end result of the community's dissatisfaction is superintendent turnover. The superintendent must work with the community if he/she is to 
remain in the superintendency. The literature indicates that the superintendent's leadership ability is key to political survival in the community.

Rist (1990), writing in The Executive Educator, did not define educational leadership style; instead, she listed traits that a leader must posses to function in the leadership role within the support of the community. The traits she listed are:

- A leader must have a thick hide. The chief executive officer must keep focused despite setbacks.

- He/she must have a sensitivity to diversity. The superintendent must recognize differences between people, which Rist believed is a result of "extraordinarily good human relationship and communication skills" (p. 15).

- The superintendent must posses charisma and should be an inspirational leader with motivational skill.

- The chief executive officer must be self-confident, being able to be comfortable with a tension between himself/ herself and the board.

- The educational leader must be possessed of a "stomach for politics" (p. 15). The superintendent must realize that board membership is political and that at least some members of the board will use the position to gain other, presumably more powerful, political office. 
- The superintendent must be "on top of it," having high energy, and be willing to work hard and long to achieve his/her goals.

- The chief executive officer must have the courage to make a stand when a clear consensus is lacking.

Blumberg (1989) chose to change the nomenclature of "style" in defining leadership. He called "style," craft. Blumberg stated that craft means that the person has a nose for the job. The craft-person can sense and understand the work environment. He/she is able to see the obvious and communicate it to the observer while realizing that the observer may not see the obvious, or understand it as he/she does. The observer may not see it in the same way as does the craftsman (p. 29). A craft, like a talent, is difficult to measure and even fellow crafts people cannot always recognize or critique leadership style. Blumberg defined leadership style as a set of "unspoken behavioral messages" (pp. 36-37)

There cannot be doubt that the superintendency is a "hot seat" (Rist, 1990, p. 15). Nor, can there be doubt that the job requires considerable leadership style. What appears in doubt is an exact definition of what constitutes leadership style or craft when dealing with the district's patrons. This is particularly true when viewed in the context of the entire community. Perhaps the closest we are able to come to a definition is to state that the 
superintendent must posses a leadership talent. This talent is a composite of several traits that may be learned, but the simplel learning of the traits does not ensure that the superintendent will have or be able to exercise leadership style. Once the traits are learned, the superintendent must use them effectively in working with the educational cormunity in the district. This combination of learned traits and the skillful use of them combines to form an individual's leadership style (Blumberg, 1989; Hess, 1986; Rist, 1990).

When a superintendent is hired by the district, the district, as represented by the hiring committee and/or the board, attempts to match its perceptions of its "self" with the traits of the new chief executive officer. As the demographic character of the district changes through growth or decline in population, economic status, aging, or any of several other factors, the superintendent will need to adjust his/her leadership to this "new" district (Johnson, 1988). The superintendent must "read" the community and adapt personal educational goals to meet those of the changing community. It is the chief executive's leadership style that |allows for the necessary adjustment and provides for the superintendent to continue to be an effective educational leader in the community. 
Problems Across Districts

School districts, nationwide, share a common set of problems. All school districts share:concerns over finances, their enrollments, their denographics, and their administration. Each of these elements can have an impact, in varying degree, on the longevity of the superintendent.

\section{Finances}

Public schools are financed through taxes. Taxes in support of public schools are levied at three governmental levels: local, state, and federal, Fiederal financial support for education is not a "direct tax." Money for education comes from the federal government through a general income tax with taxpayers unaware of what portion is dedicated to education. State and local taxes for education are "direct taxes" with taxpayers able to know how much of their "tax dollars" goes to education.l Historically, local governments have levied taxes for schools against real property. Beginning in the mid 1970s, the nation has been in the throes of what has become popularly known as a "taxpayer revolt." The taxpayer revolt is at least partially possible because of the differentiation between direct and non-direct taxes. This "revolt" has taken the form of legislation designed to limit the amount of tax dollars that can be levied against a given piece of property. Oregon and California on the west coast, colorado 
and Michigan in the midwest, and Massachusetts and Delaware on the east coast have passed property tax limitation legislation (B. Sharp, personal communication, January 30 , 1995). As a result of successful property tax limitation efforts, school districts were faced with a difficult, if not impossible, task of financing themselves with increasingly limited available resources.

It is obvious that the reduction or elimination of a source of income for a school district will place demands on those funding sources that remain, creating a situation where all school districts will be in greater competition for the remaining funds. The National Center for Education statistics listed the following facts pertaining to the financing of school districts (B. Sharp, personal communication, January 30, 1995):

- Since 1920 state and local governments have been the primary sources of financing for schools, while the federal share of the financing has been comparatively small.

- In 1979 the states' share of revenues rose above the local contribution for the first time.

- The total average expenditure per pupil has quadrupled since 1950.

- Between the years of 1970 and 1988, all states recorded a substantial percentage increase in school expenditures. 
These statements confirm the fact that the task of financing school district operations is becoming increasingly difficult for the individual charged with the primary responsibility of building the district's budget, the superintendent. As the educational and business leader in a school community, the establishment of curriculum, its maintenance, and its financial support are the responsibility of the chief executive officer. The duality of the role of superintendent as both the educational and business leader in the district has placed him/her in the precarious position of having to attempt to balance the demands for ever-increasing curriculum against the reality of the ever-decreasing dollar. Wilson and Heim (1984) reported that the decline in economic support for districts in Kansas, from 1978-1984, was a major factor in those districts that experienced a higher than average superintendent turnover rate. The resulting dichotomy contributes to a "conflict between old and new values" in the educational community, which often places the superintendent in conflict with one or more members of his/her board of directors (Iannaccone \& Lutz, 1970, p. 29).

\section{Curriculum/Demographics}

Another concern that superintendents must face is the changing demographics in their districts. Demographic changes in the community create situations where values are shifted (Finnie \& Sniffin, 1984, p. 42). Chief executives 
need to be aware of any movements in the principles and beliefs of the community, make their boards aware of these shifts, and incorporate them into their districts' curriculum in order to be successful in the eyes of their communities (Fuller \& Martin, 1991). The curriculum that a district presents reflects the morays of the district's patrons and therefore curriculum and demographics appear in the literature to be inseparable. Within limits, each state has allowed local school boards discretion in curricular areas. There is no question that board members are frequently elected to their positions solely or in part based on curricular values (Arnez, 1981). Changes in demographics can change majority opinion in the district. Changes that may or may not be reflected on the board of directors. In combination, changes in the demographics of a community and reduced financial support for curricular change, indeed maintenance of the curriculum, create a situation where problems associated with curriculum can and do impact the longevity of the superintendent (Firestone, 1980; Iannaccone \& Lutz, 1970; Zeigler, Kehoe, \& Reisman, 1985).

Washington county, Oregon contained 13 school districts in 1993 (Washington County Department of Land Use and Transportation, 1993). According to the county, all of the districts experienced varying degrees of population increase. People have come to the county from other areas 
in oregon and from across the nation. One district has been experiencing community pressure from a conservative religious group over curriculum issues for several months. None of the other 13 districts is experiencing similar pressure. Local newspaper articles indicate that the movement of people into the state will create a situation where this kind of pressure will spread to other school districts, as the conservative religious group gains membership and those members disperse to other districts. According to the newspaper, this is not due to any plan, but to the way in which the county's population is increasing and shifting; the cause is demographic (Staff, 1991). clearly demographics are impacting curriculum and curriculum decisions in at least one Washington county school district. That impact will be felt across other districts, as the conservative element moves and gains strength across the county. Iannaccone and Lutz $(1970,1978)$ in their "dissatisfaction theory of American democracy" stated that citizens do not become politically active until a high|level of dissatisfaction is felt. Johnson (1988) stated that changes in the community can be a factor in creating dissatisfaction. Obviously, changes in community values result from a number of sources, one of which is the movement of people either into or out of a school district. 


\section{Administration/Leadership}

The literature discusses leadership traits that superintendents should possess in order to maintain their positions. Characteristics enumerated in the literature that are requisite to strong leadership include a need for awareness of the support community (Anderson \& Lairwers, 1978, p. i), politics, sensitivity, and charisma (Rist, 1990). There is no discernible difference between educational leadership and other types of leadership, nor is there a discernible difference in the importance of leadership style in the arena in which it is exercised. Leadership style is no less important in one arena than it is in another. The literature indicates that there are traits, whether labeled, "craft or art," which determine leadership (Blumberg, 1989; Rist, 1990). These traits are expressed by the successful leader in conjunction with a perceived need from the community (Fuller \& Martin, 1991). The community needs may be expressed either directly by patrons of the community, or indirectly through the school board as community representatives. Fuller and Martin, writing in The Executive Educator, enumerated what appear to exemplify leadership traits throughout the literature. They stated that a leader:

- Establishes clear and open communication.

- Builds trust by being fair, ethical and honest.

- Displays cordiality and professionalism. 
- Involves others in the planning process.

- Knows how to live with and handle conflict.

- Has come to terms with their own principles and beliefs.

- Devotes time and effort to the training of the board.

- Ensures that the board is recognized for its efforts. Fuller and Martin (1991) appeared to agree with Blumberg (1989) that an "emphatic presence" is requisite to successful educational leadership. It is also apparent that the literature makes no differentiation between the several terms used to label successful leadership. The terms, "trait, style, art, and craft" are used synonymously throughout the literature. The literature indicates that superintendents who do not practice strong leadership cannot exercise good administration.

The position of superintendent is unique in the district, and as such the person holding that office must also be somewhat unique (Fuller \& Martin, 1991). The leadership style of the individual must correspondingly reflect that uniqueness. When the chief executive officer's leadership does not match the community's perceived need, the superintendent will be faced with dismissal or nonrenewal. One such case is discussed by Renchler (1992), concerning turnover in the seattle, Washington superintendency. He stated that superintendents will seek to protect themselves from summary dismissal through their 
contract with the board. The chief executive officer is the only employee who is hired and evaluated directly by the board. This person serves at the pleasure of the board. The terms of employment (contract) under which the superintendent works are therefore critical.

\section{Contract}

The literature reflects the importance of the superintendent's contract. Hess (1986) pointed out that the office of chief executive officer is where "the buck stops." He believed that the role the superintendent plays in the district is highly political and that the board is the only protection that a superintendent has against loss of position resulting from unpopular, although necessary and effective, administrative decisions.

District: politics tend to maximize the search for consensuls and avoid open conflict, creating opportunity for the manipulation and control of school boards and educational policies by relatively small and narrowly based cliques. (Iannaccone \& Lutz, 1970, p. 29)

Bryant and Grady (1991) surveyed 81 school superintendents who faced non-renewal and found that $23 \%$ suffered problems with relatives or close friends of members of the surveyed superintendents' boards. In $21 \%$ of the cases, superintendents were removed from their positions because the board had a "personal agenda." Only $18 \%$ of the superintendents who were removed from their offices were removed due to a perceived lack of performance. 
Compounding the problem of political removal from office is the fact that fewer than $15 \%$ of the nations school districts provide administrative tenure (Crook \& LaFleur, 1975, p. 1). As a "quasi-corporate" body, the school board has the legal authority to run the school district by itself. There are only three reasons why boards do not assume the task of running the district themselves: (a) the system is too complex for non-professionals to manage, (b) there is too great a chance for a political patronage system to be established, and (c) there is a body of trained professionals available (Blumberg \& Blumberg, 1985, p. 25). The Blumbergs strengthen the concept that the superintendent serves at the pleasure of the board. Unfortunately, school board membership does not remain static. In 1990, the median length of service for board members nationally was five years (Heller, Woodworth, Jacobson, \& Conway, 1991). The literature is unanimous in stating that any protection the chief executive officer has against the political problems of maintaining his/her district lie in a contract with the board (Bolton, 1980; Doob, 1974; Greenwood \& Zirkel, 1990; Harris, 1977; Hess, 1986).

A standard superintendent's contract in 1970 might include conditions of employment, salary, fringe, duties, and provisions for renewal (Harris, 1977). Later publications by the Barraclough (1979) and Educational Research Services (1979) placed provisions for renewal or 
non-renewal variously in juxtaposition in the contract. None of the literature concerning contracts specified the methodology of evaluation for the superintendent. Bolton (1980, p. 150) stated that there are three reasons for evaluation of the superintendent:

1. The schools are expected to be responsible for problems of behavior, motivation, and for the attitudes of the students.

2. Professional decisions are open to question by district employrees and patrons.

3. Many view public officials as responsive only to public pressure.

However Bolton (1980) did not relate superintendent evaluation to job security for the superintendent. I He quoted the Educational Research Service in its report on administrative evaluation across the nation in 1985 , excluded suplerintendent evaluation, and began its summary report with the office of deputy/assistant superintendent.

Blumberg (1989) stated that the maintenance of a strong contract, including provisions for evaluation, is critical in providing for the emotional and political support of the chief executive officer (p. 125). Bennett (1991), the superintendent of st. Paul Public Schools, writing in the American School Board Journal, discussed the changes he believed had occurred in the composition of school boards over the past three decades. He stated that, in the 1960s, 
school boards were composed of "civic minded" volunteers who were serving on the board after having found success in their chosen professions and were "paying society back" for the benefits they had received from it. During the 1970s and into the 1980s, school boards tended to be composed of more females and persons "of color." Bennett believed that this change was a result of the civil rights movement in America and that the new boards maintained their civic mindedness. Current boards, according to Bennett (1991), are composed of people who are more of a political mind than of a civic mind. He stated that present day boards are unlike the previous types of boards in that:

This type of board member does not evidence any special interest in education above and beyond elected service in a political office. This board member behaves like any other political office holder, concerned primarily with reelection or higher political office and paying assiduous attention to serving political constituents. ( $p$. 47)

Given this information, it appears that the major source of job protection for the chief executive officer is his/her contract with the board and that the contract must include specific, periodic evaluation language.

\section{Incumbent Defeat and Involuntary Turnover of the superintendent}

of the many factors that can and do cause involuntary turnover in the office of the superintendent, only limited study has been devoted to the relationship, or lack thereof, 
between incumbent board member defeat and the involuntary replacement of the superintendent. Since Walden's 1966 study, several attempts have been made to confirm or deny his hypothesis that incumbent defeat and involuntary superintendent turnover are positively related. The data found in the literature is inconclusive.

Flanning conducted research as a part of his doctoral studies in 1989. He surveyed all of the school districts in Alabama which were impacted by a new Alabama state Law that reduced the term length of board members from six to four years. There were 501 school districts impacted by the law. As one might expect, there were many turnovers in board membership; however, Flanning could not discover a correspondingly large number of turnovers in superintendencies. He was, in fact, only able to discover one statistically significant case. There is a major flaw in trying to compare this study with Walden's (1966). There is no data in the Flanning study that speaks directly to whether the board members who lost their positions on the board as a result of the law stood in following elections as incumbents and therefore also no data to tell us if they were successful or unsuccessful in their attempts for reelection.

McCarthy and Ramsey (1971, pp. 19-22), while not specifying that incumbent board member turnover had an impact on superintendent turnover, did state that boards 
take on the personality of their superintendents. They labeled these boards and the corresponding superintendent personality as follows:

1. Dominated boards, managed by a superintendent that McCarthy and Ramsey call the "functionary" superintendent. These boards reflect a clearly dominant community group.

2. Factional boards, managed by the "political strategist" superintendent, represent a community where the power structure is factional in nature.

3. Status congruent board, managed by a superintendent who acts as the professional advisor to the board. The board represents a pluralistic society.

4. Sanctioning board, managed by a superintendent who is the decision maker. These boards are representative of a community that has expressed no clear direction to its board.

If we give credence to Mccarthy and Ramsey, and there are boards which may be categorized in this manner, then it seems apparent that a change in board membership could have an impact on the style that the superintendent has assumed in managing the district. If that change were to be "unfriendly" to the existing board power structure, as represented by incumbent defeat, the superintendent could be faced with having to change his/her management style to maintain his/her success with the board or face dismissal. There are other studies which speak to the inverse--that is, 
that the removal of the superintendent can result in incumbent defeat (Hoseman, 1990). It appears, then, that change in the management style of the chief executive officer should be a cooperative effort between the board and the superintendent.

When the board searches for a new superintendent, the board needs to find a chief executive officer to match the personality of the board (Flanning, 1984). Four of the six skills boards look for in choosing a superintendent have to do with "getting along" with the board. Flanning listed "willingness to cooperate, public relations skills, communication skills, and human relationship ability" as requisites for superintendent applicants. As one might expect the other two skills are "leadership and decision making ability." His research confirmed the work of McCarthy and Ramsey's (1971), in statements that boards and superintendents assume matching personalities.

Adding to this concept of "personality match" between the board and its chief executive officer is the work of Wood (1990). She determined, through her research, that $95 \%$ of the superintendents she surveyed felt an obligation to honor commitments that they had made to previous boards even after the composition of the board had changed through resignation or through the election process. However, only $65 \%$ of the board chairmen agreed that these commitments should be honored. One wonders at the disparity of 30 
percentage points between the board chair's and the superintendent's desire to honor previous commitments.

\section{Summary}

This chapter has presented a brief overview of the literature pertaining to the longevity of the superintendent in his/her office. The literature discusses five major areas that influence superintendent longevity: superintendent relationships with his/her staff and community; the community, including socio-economic and demographic characteristics; problems that are common across districts; the relationship the superintendent has with his/her board of directors; and the effect of incumbent defeat on longevity in the office of superintendent. All five areas impact the performance of the chief executive officer and all five areas can create situations for the superintendent that can lead to his/her dismissal irom office. The literature does not prioritize the five areas in importance; however, communication/relationship and leadership style appear to be present in all five areas. How well the superintendent communicates and relates to the educational community, the job, and the board of directors are threads that run through all of the areas discussed. The impact of incumbent board member defeat in standing for reelection has been studied with varied results. Perhaps this is due to the same kind of phenomena noted in 
discussions of effective leadership; there is no single factor that will cause turnover in the office of the superintendent. The literature appears to confirm the hypothesis that no single factor can be held exclusively as the factor in superintendent turnover. 
CHAPTER III

\section{METHODOLOGY}

As finances for schools becorne increasingly limited, pressure is going to be placed on school boards to find ways to do more with less. As the chief executive officer in the district, the superintendent/will be expected to guide the board in this process. School finance will not abrogate other problems facing districts. Patrons will continue to expect the local district to reflect the community's morays. In combination, political pressure on the schools to be "all things to all people" will grow. The climate is appropriate for a study of the factors related to the longevity of the superintendent and incumbent |board member turnover.

\section{Design}

This was a descriptive study A mailed questionnaire was sent to all superintendents of districts governed by five-member school boards (Appendix A). The purpose of the study was to examine the factors related to the longevity of the chief executive officer and members of his/her school board. The study examined the issues surrounding the replacement of the superintendent and incumbent board members during a five-year period, The data were gathered 
in an attempt to clarify the relationship, if any, of the longevity of the superintendent after an incumbent board member failed in a reelection attempt. It was assumed that, when an incumbent board member failed in his/her bid for reelection, the failure represented a change in the community power structure and that the change in power structure would correspondingly impact the superintendent through the loss of his/her position.

The research questions addressed in this study were:

1. What are the turnover rates within five years for:
a. superintendents?
b. incumbent board members?
c. superintendents when an incumbent board member

fails to be reelected?

2. What are the factors associated with board member turnover?

3. What are the factors associated with superintendent turnover?

4. Are there variables which may be used together to discriminate between categories of superintendent turnover?

5. What is the relationship of district size and number of schools in the district to superintendent turnover?

6. What is the relationship of geographic location of the districts to superintendent and board member turnover? 
7. What is the relationship of the type of district (elementary, high school, or union high school) to superintendent and board member turnover?

\section{Sample}

In July of 1993, 179 districts were identified through the Oregon state Department of Education (1994) as meeting the study's criteria of being a school district with a fivemember school board and a superintendent. Questionnaires were mailed in that month to all of these districts. Initial response to the questionnaire and some follow-up telephone calls reveled that of the 179 districts that were mailed a questionnaire, six were disqualified due to consolidation, and 25 additional districts did not employ a superintendent. The boards of these districts manage their districts with the assistance of deputy clerks. One district responded that it has a school board and a superintendent but tuitions all of its students to another district. The number of districts that remained as qualifying districts was therefore reduced to 147 . By using follow-up procedures, the researcher was able to gather 116 valid responses from those 147 qualifying districts. These districts are listed in Appendix C. With 147 possible districts, the response from 116 districts represents a $78.9 \%$ return. 
It is interesting that, while the district mentioned earlier has no students (they are tuitioned to another district), it maintains a school board of five members that must meet a minimum of three times annually in open session. The board must meet to organize itself, to organize and deliberate on an annual budget, and to adopt the budget (Oregon Ballot Measure \#5, 1990; ORS 332.011 \& ORS 332.515 cited in Oregon Department of Education, 1991). This district, technically, has no superintendent and was, therefore, unable to reply to the questionnaire. A second district responded, to a telephone contact, that the superintendent had left the previous day for another position--and had left no forwarding address. The person contacted was unable/unwilling to respond beyond the information already given to the researcher. It was discovered that several districts were small enough that they do not remain open during the summer break so that by the time follow-up would have been possible, analysis on data previously received had already begun. of the 31 nonresponding districts, it would be unreasonable to expect at least two of those districts to have responded. If those districts are factored into the response rate, the rate becomes $80.3 \%$. 
Instrumentation

The data used in this study came from two primary sources: the questionnaire and from published public documents. Publications concerning student enrollments, district size, and demographic data were available through the oregon Department of Education (1994; Oregon school districts, July 1993).

Questionnaire

A questionnaire was constructed based on the literature, discussions with other local superintendents, and the researcher's personal experiences. The initial questionnaire contained 17 open ended, free response and limited response questions. A cover letter stating that this was an initial questionnaire and that those chosen to respond to the questionnaire were to do so as: (a) a superintendent, and (2) a person who could be critical of the questions themselves ( $\mathrm{Did}$ the questions require explicit responses or were they unclear?) was written and mailed with the initial questionnaire. The questionnaire addressed the following:

- The number of months the current superintendent has been in office in the district.

- The previous position held by the current superintendent. 
- Whether there was $\mid$ an interim superintendent in office before the current superintendent assumed the duties of superintendent and if so, the number of months that the interim superintendent served.

- The position that the previous, full-time, superintendent now holds|both inside and/or outside of education.

- Whether there was $\mid a$ bond attempt during the past five years and the result of that attempt.

- The political climate in the district at the time the current superintendent assumed his/her current position as well as follow-up questions concerning the predecessors' relationship with the board of directors at the time he/she left the district.

- The number of board positions open for election and the nature of the resulting elections.

- The average length of service for board members in the district serving during the past five years.

- The impact, if any other than financial, that the current superintendent feels oregon Ballot Measure \#5 (1990) is having on the district and his/her relationship with the board of directors.

- other difficulties the current superintendent is facing in working with his/her current board of directors.

- Free-response data concerning the current superintendents" satisfaction in his/her current position. 
the Superintendent of the Washington county Educational Service District and to 10 building-level administrators throughout Washington County, oregon. The purpose of the field test was to determine if the questions on the inventory yielded the data needed for the study as well as to ensure that the questions asked were understandable.

The field test pointed out two "awkward" questions which were subsequently re-written so that they were clearer as to intent. One error in the numbering of the questions was pointed out as well.

After revising the initial questionnaire a second cover letter was written explaining that the questionnaire attached was a part of a research dissertation and emphasizing that all responses would be held in confidence. The second cover letter and revised questionnaire were then mailed to the qualifying districts (see Appendix A).

\section{Publications}

This study scrutinized the districts' demographics to determine those factors that the researcher felt might influence the longevity of the superintendent or the non-reelection of incumbent board members. District size, as measured by the number of students and teachers, in the district, was studied. This information was readily available through the state Department of Education records and is a matter of public record. Finally growth and/or decline in student population was studied. Whenever further 
and is a matter of public record. Finally growth and/or decline in student population was studied. Whenever further clarification was necessary concerning demographic data gathered, the state or other sources were contacted by telephone so that data were cross referenced from district records. All of the demographic data necessary to this study was and is a matter of public record.

Telephone communications provided the most usable source of information in clarifying questions concerning individual districts. The researcher called or faxed 20 individual districts seeking additional information, or clarification of information submitted on returned questionnaires. These contacts made it possible to know that one superintendent had resigned and left the district a few hours before the follow-up contact was made. The person with whom the contact was made did not know where or how to contact the departed superintendent. In another instance, the superintendent with whom contact was made was himself, an interim superintendent. That knowledge enabled the researcher to clarify some responses made on the corresponding questionnaire.

\section{Data collection Procedures}

The revised questionnaire was mailed to all 179 school districts in the state of oregon governed by five-member school boards during July 1993. Initial responses to the 
questionnaire indicated that 147 districts actually qualified as having a superintendent, a five-member school board, and a currently operating school district. The following were factors in the reduction of the original number:

1. The school board manages the district and there is no superintendent.

2. The district has been or is currently being consolidated with another district and the most recent superintendent was unavailable. [A 1991 Oregon state law mandated consolidation of elementary districts with high school districts by 1996 (ORS 330.310 cited in oregon Department of Education, 1991).]

3. The school district no longer exists. (Too few students, and one of the above existed prior to the district's dissolution.)

If the questionnaire was not returned, or if there were responses to the questions on the questionnaire that needed clarification, a telephone call or facsimile was used. The researcher made 20 telephone contacts during the september 1993 in a successful attempt to increase the number of valid responses to the questionnaire or to clarify existing responses. It was not possible to determine, at the outset, all of the possible responses which might precipitate a follow-up interview; however examples of responses that did qualify are: 
1. A response(s) was left blank and could not be gained through interpolation with other responses.

2. A question called for a single response but received multiple answers.

3. When responses indicated that further information was necessary for the respondent to be able to reply.

of the 147 qualifying districts, 116 districts submitted complete questionnaires, or questionnaires that could be completed through the follow-up procedure outlined above. Follow-up was possible because each questionnaire was numbered so that responses to the initial mailing could be tracked. When no response was received, or when one of the above listed cases of incomplete data was found, the follow-up procedure was implemented. However all data were recorded, manipulated, and stored in such a manner as to guarantee the confidentiality of individual responses and respondents.

\section{Analysis}

For those questions that yielded nominal or ordinal data with limited response categories, frequency distributions and percentages were used. For interval and ratio data (e.g., number of years of service), means and standard deviations were used. Content analysis was used to identify themes and categories for open-ended questions. For examination between superintendent turnover and various 
items or questions, cross tabulations were used. The analysis necessary to examine the research questions required an examination of the relationship between nominal and ordinal variables. For example, the relationship between superintendent turnover and political climate was examined by cross tabulation and chi-square, testing the statistical hypothesis that superintendent turnover and political climate are independent. For each variable that had a curvilinear relation with superintendent turnover, the absolute departure from a specified "typical" value was calculated and used in the analysis. For example, with the assumption that five to eight elections was normative, it was given the value of zero; four and nine were assigned the value of one, three and zero elections were assigned the value of two, and so on. The specific procedure used for each of the curvilinear variables is discussed in chapter IV. 
CHAPTER IV

\section{PRESENTATION, ANALYSIS AND DISCUSSION OF DATA}

\section{Introduction}

This descriptive study used a structured questionnaire and information available from public records to investigate the factors related to the failure of incumbent board members to be reelected and turnover in the office of the chief executive officer in public school districts governed by five-member boards. The study was motivated by a desire to examine a basic assumption that superintendent turnover is associated with board member turnover, and the research hypothesis associated with this assumption was tested during this study. Included in this chapter are the statistical analyses used in attempting to provide answers to the questions posed in Chapter I of this study as well as to furnish evidence for accepting or rejecting the primary hypothesis that a relationship exists between involuntary turnover of board members as represented by defeat as an incumbent standing for reelection and turnover in the office of the district's chief executive officer within a time period of five years.

The research questions examined for this study were: 
1. What are the turnover rates within five years for:

a. superintendent?

b. incumbent board members?

c. superintendents when an incumbent board member

fails to be reelected?

2. What are the factors associated with board member turnover?

3. What are the factors associated with superintendent turnover?

4. Are there variables which may be used together to discriminate between categories of the superintendent turnover?

5. What is the relationship of district size and number of schools in the district to superintendent and board member turnover?

6. What is the relationship of geographic location of the districts to superintendent and board member turnover?

7. What is the relationship of the type of district (elementary, high school, or union high school) to superintendent and board member turnover?

Chapter IV contains an analysis of district characteristics, descriptive data concerning current superintendents, and turnover rates for both superintendents and board members. 
District Characteristics

Districts are described in terms of size, as measured by both student enrollment and the number of teachers employed, geographical location, and by district type (elementary, high school, or $\mathrm{k}-12$ ). Districts are also described by problems that they reported facing.

\section{size}

Table 1 presents the distribution of the number of teachers and students in the surveyed districts as grouped data. Statistical analysis of that data is based on non-grouped data. Districts in this study range in size from districts of four teachers and six students to districts with 555 teachers and 10,914 students. The median district in the study had 32 teachers and 517.5 students. The teacher to student ratio across all of the districts in the sample was $19.66: 1$. No data were gathered on the ratio of the number of administrators to students.

It should be noted that the largest metropolitan and suburban districts in oregon are governed by seven member boards and were therefore excluded from this study. only 9,162 teachers and 171,816 students are represented in the study. Portland is the largest city in Oregon. Portland Public Schools employs 2,742 teachers for 54,975 students. Beaverton, a suburb of Portland, employs 1,303 teachers for 27,160 students. Both districts were excluded from the 
study due to their governance by boards larger than five members (Oregon Department of Education, 1994, pp. 55, 68).

Table 1

Number of Teachers and Students

\begin{tabular}{|c|c|c|c|c|c|c|c|}
\hline & Nun & of $T$ & ers & & umber & tud & \\
\hline Grou & ping & $\underline{f}$ & $q$ & Grouping & & $\underline{\mathbf{f}}$ & $\frac{q}{8}$ \\
\hline $\begin{array}{r}285 \\
275 \\
265 \\
255 \\
245 \\
235 \\
225 \\
215 \\
205 \\
195 \\
185 \\
175 \\
165 \\
155 \\
145 \\
135 \\
125 \\
115 \\
105 \\
95 \\
85 \\
75 \\
65 i \\
55 \\
45 \\
35 \\
31 \\
25 \\
22 \\
19 \\
16 \\
13 \\
10 \\
7 \\
4\end{array}$ & 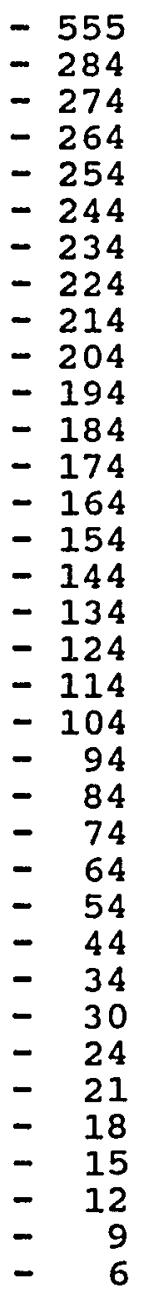 & $\begin{array}{r}9 \\
1 \\
0 \\
0 \\
0 \\
0 \\
2 \\
1 \\
1 \\
0 \\
1 \\
0 \\
1 \\
5 \\
1 \\
1 \\
3 \\
1 \\
1 \\
1 \\
1 \\
6 \\
2 \\
1 \\
6 \\
8 \\
6 \\
4 \\
4 \\
4 \\
7 \\
10 \\
9 \\
8 \\
11\end{array}$ & $\begin{array}{l}7.76 \\
0.86 \\
0.00 \\
0.00 \\
0.86 \\
0.86 \\
1.74 \\
0.86 \\
0.86 \\
0.00 \\
0.86 \\
0.00 \\
0.86 \\
4.31 \\
0.86 \\
0.86 \\
2.59 \\
0.86 \\
0.86 \\
0.86 \\
0.86 \\
4.31 \\
1.74 \\
0.86 \\
5.17 \\
6.90 \\
5.17 \\
3.45 \\
3.45 \\
3.45 \\
6.03 \\
8.62 \\
7.76 \\
6.90 \\
9.48\end{array}$ & $\begin{array}{r}10,001+ \\
9,001- \\
8,001- \\
7,001= \\
6,001- \\
5,001- \\
4,001- \\
3,001- \\
2,001- \\
1,901- \\
1,801- \\
1,701- \\
1,601- \\
1,501- \\
1,401- \\
1,301- \\
1,201- \\
1,101- \\
1,001- \\
901- \\
801- \\
701- \\
601- \\
551- \\
501- \\
451- \\
401- \\
351- \\
301- \\
251- \\
201- \\
151- \\
101- \\
51- \\
1-\end{array}$ & $\begin{array}{r}10,000 \\
9,000 \\
8,000 \\
7,000 \\
6,000 \\
5,000 \\
4,000 \\
3,000 \\
2,000 \\
1,900 \\
1,800 \\
1,700 \\
1,600 \\
1,500 \\
1,400 \\
1,300 \\
1,200 \\
1,100 \\
1,000 \\
900 \\
800 \\
700 \\
600 \\
550 \\
500 \\
450 \\
400 \\
350 \\
300 \\
250 \\
200 \\
150 \\
100 \\
50\end{array}$ & $\begin{array}{r}1 \\
1 \\
0 \\
1 \\
7 \\
0 \\
5 \\
3 \\
10 \\
1 \\
1 \\
1 \\
1 \\
0 \\
1 \\
3 \\
1 \\
1 \\
4 \\
2 \\
2 \\
3 \\
6 \\
2 \\
1 \\
5 \\
2 \\
1 \\
4 \\
3 \\
11 \\
9 \\
9 \\
10 \\
4\end{array}$ & $\begin{array}{l}0.86 \\
0.86 \\
0.00 \\
0.86 \\
0.03 \\
0.03 \\
0.00 \\
4.31 \\
2.59 \\
8.62 \\
0.86 \\
0.86 \\
0.86 \\
0.86 \\
0.86 \\
0.00 \\
0.86 \\
2.59 \\
0.86 \\
0.86 \\
0.86 \\
3.45 \\
1.72 \\
1.72 \\
2.59 \\
3\end{array}$ \\
\hline $\begin{array}{l}\text { Mini } \\
\text { Mean } \\
\text { Medi } \\
\text { Stan }\end{array}$ & $\begin{array}{l}\text { Imum } \\
278 \\
\text { ian } 32 \\
\text { hdard }\end{array}$ & & & $\begin{array}{l}\text { Mea } \\
\text { Med } \\
\text { Sta }\end{array}$ & $\begin{array}{l}\text { um } 1 \text {, } \\
1481 \\
\text { n } 517 \\
\text { ard }\end{array}$ & & \\
\hline
\end{tabular}


For the purposes of analysis, information concerning district size was further divided into; "small districts" with teacher numbers from four to 15 and students number range from one to 200 , "medium districts" with teacher numbers from 16 to 54 and student numbers from 201 to 600 , and "large districts" with teacher numbers from 55 to 555 and student numbers from 601 to 10,000. This division allowed the researcher to study the relationship of variables to the entire group as well as to the sub-groups of small, medium, and large districts. This sub-grouping is noted in Table 1 by spaces located at the break points for each groups. A break also occurs to denote gross changes in the ranges as when the student counts change from blocks of 100 to blocks of 1,000 . The small group contains 38 districts ( $33 \%$ of the sample), the medium group contains 39 districts ( $34 \%$ of the sample), and the large group contains 39 districts, ( $34 \%$ of the sample) of the 116 districts (see Table 1).

\section{Geographic Location}

Districts included in the study were evenly dispersed across the state (see Figure 1). Nine counties out of 36 are not represented by districts contained wholly within the counties' boundaries. It should be noted that school districts in oregon are not constrained by county boundaries and many districts carry the suffix after their designation of "J" or "JT" indicating that these districts have 
boundaries which cross county lines. Five of the counties, in which no single district is totally contained, are located in the eastern area of the state and four are located in the coastal area. All of the counties located in the valley area of the state responded. Responses were gathered from 27 (75\%) of the counties in the state. The nine counties not responding are dispersed throughout the state so that no pattern can be established or inference drawn from the lack of response in a given geographical area.

Demographic Zones

By using natural geographical features (there are two mountain ranges, the coast range and the Cascade range, which are separated by a river valley), the state may be divided on a North-South axis into three separate demographic zones. These zones are the coast, valley, and eastern areas of the state. All of the zones are represented by responses from school districts located inside of them.

The coastal zone extends from the Pacific Ocean inland some 50 miles to the center of the coast Mountain Range. This zone is supported economically through fisheries and tourism. It is the second most densely populated zone. The valley zone lies between the coast Range and the Cascade Mountain range. It contains the largest population density and the state's major cities. The valley zone is divided 
vertically in half by Interstate 5, (I 5). The valley zone draws its financial support from industry, the state's major port, tourism, and agriculture. The eastern zone extends from the Cascade Range to the state's boundaries with Idaho. This zone contains the greatest land mass and the least population as it is primarily agricultural with tourism as its second means of financial support (see Figure 1).

\section{District Type}

The state has traditionally divided its school systems into three categories: elementary school districts serving students in grades $\mathrm{K}-8$, high school districts serving students in 9-12; and union high school districts serving students in $\mathrm{K}-12$. Oregon recently passed a state law requiring all elementary districts to consolidate with the union high school district to which the elementary district sends its high school students (Consolidation Law cited in Oregon Department of Education, 1991). This mandate may account for the fact that of the responding districts, 74 (64\%) were union high school districts, 32 (28\%) were elementary districts, while only 10 (9\%) were high school districts. The law mandates that all districts be consolidated into union high school districts by 1996 (see Table 2) . 


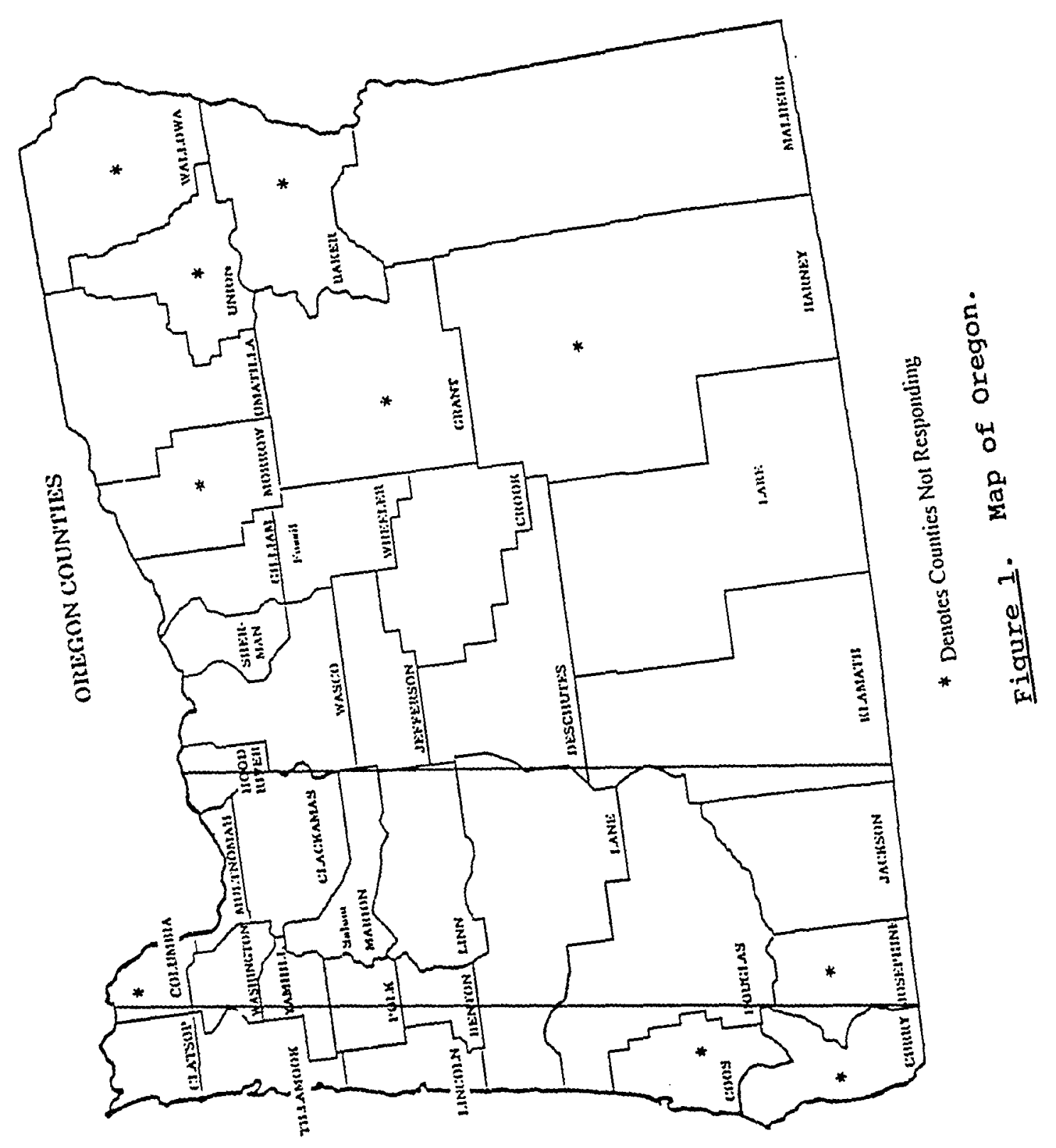


Table 2

District Type

\begin{tabular}{lcr}
\hline Type & $\underline{\underline{f}}$ & $q$ \\
\hline Elementary & 32 & 27.59 \\
High School School & 10 & 8.62 \\
Union High School & 74 & 63.79 \\
\hline
\end{tabular}

\section{District Problems}

There were three open-ended questions in the questionnaire that dealt with problems faced by school districts. The questions asked superintendents about their concerns over oregon Ballot Measure \#5 (1990) and its possible impact on superintendent/board member relationships, the biggest single problem the superintendent felt his/her district was facing, and what the superintendent felt was causing the greatest problem between himself/herself and the board.

\section{Ballot Measure \#5}

As might be expected, school finance was considered by current superintendents to be the greatest problem facing their district $(61 \%)$. Finances have always been a problem with school management. However this problem has been aggravated due to the passage, in oregon in 1990, of Ballot Measure \#5, a property tax limitation law. Measure \#5 causes property taxation to decrease to $\$ 5$ per $\$ 1,000$ of 
property value by the year 1995. School districts will then be "locked in" to that rate until the law is changed.

A majority of current superintendents (68\%) reported that oregon Ballot Measure \#5 (1990) had created no problems with their relationship with their boards. Some of these superintendents (18\%) reported that there was some conflict between what the board expected and what the chief executive officer was able to accomplish perhaps as a result of the financial restrictions of Ballot Measure \#5. However, it does not appear that this legislation has greatly impacted the relationship between the superintendent and his/her board (see Table 3).

\section{Current Problems Faced by School Districts}

The current superintendents were asked to identify what they felt was the biggest problem faced by their district. They (61\%) reported that finances was the most serious problem facing their districts. Another recently passed law, Oregon Educational Act for the 21st Century (1991), mandated that by the year 1996 elementary school districts will have consolidated with the high school districts. This "forced consolidation" law was seen by current superintendents as the second largest problem (10\%) faced by districts today. This may partially explain why $18 \%$ of the current superintendents identified conflicts between their boards' expectations and the superintendents' 
accomplishments as $\mid$ a problem associated with oregon Ballot Measure \#5 (1990) (see Table 3).

It is interesting to note that, while $18 \%$ of the current superintendents felt that oregon Ballot Measure \#5 (1990) was impacting their relationship with their boards, more of the superintendents perceived the Consolidation Law (cited in oregon Department of Education, 1991) as impacting their relationship|with their boards (see Table 4). Other problems i.dentified concerned the board of directors (11\%), student demographics (10\%), staff problems (3\%), and factors in the community such as apathy and location (4\%).

Table 3

Impact of Measure 5 on Superintendent Board Relationships

\begin{tabular}{lcc}
\hline Responses & $\underline{f}$ & f \\
\hline Personnel problems & 1 & 0.86 \\
Relationship with the board & 1 & 0.86 \\
Forced merge & 2 & 1.72 \\
Crises management | & 2 & 1.72 \\
Loss of authority | & 2 & 1.72 \\
Politics in the community & 3 & 2.59 \\
Insufficient time to plan & 5 & 4.31 \\
Conflict between board demands & & 18.10 \\
and superintendent ability & 21 & 968.10 \\
No problems & 7 & \\
\hline
\end{tabular}


Table 4

Current superintendent Perception of Problems Faced by School Districts

\begin{tabular}{|c|c|c|}
\hline Problem & $\underline{f}$ & 8 \\
\hline $\begin{array}{l}\text { Finances } \\
\text { Consolidation }\end{array}$ & $\begin{array}{l}71 \\
12\end{array}$ & $\begin{array}{l}61.21 \\
10.34\end{array}$ \\
\hline $\begin{array}{l}\text { BOARD } \\
\text { Board/superintendent roles } \\
\text { Board member experience } \\
\text { Board staff relations }\end{array}$ & $\begin{array}{l}13 \\
(7) \\
(3) \\
(3)\end{array}$ & $\begin{array}{l}11.21 \\
(6.03) \\
(2.59) \\
(2.59)\end{array}$ \\
\hline $\begin{array}{l}\text { STUDENTS } \\
\text { Rising/falling enrollments } \\
\text { Dropout.s } \\
\text { English as a second language } \\
\text { Not enough time }\end{array}$ & $\begin{array}{l}12 \\
(7) \\
(1) \\
(1) \\
(3)\end{array}$ & $\begin{array}{l}10.34 \\
(6.03) \\
(0.86) \\
(0.86) \\
(2.59)\end{array}$ \\
\hline $\begin{array}{l}\frac{\text { STAFF }}{\text { Relationships with teachers }} \\
\text { Staff motivation }\end{array}$ & $\begin{array}{l}3 \\
(2) \\
(1)\end{array}$ & $\begin{array}{l}2.59 \\
(1.72) \\
(0.86)\end{array}$ \\
\hline $\begin{array}{l}\text { CoMMUNITY } \\
\text { Apathy in the community } \\
\text { Rural location } \\
\text { Disaster in the district } \\
\text { Number of retired superintendents } \\
\text { in the district }\end{array}$ & $\begin{array}{l}5 \\
(2) \\
(1) \\
(1) \\
(1)\end{array}$ & $\begin{array}{l}4.31 \\
(1.72) \\
(0.86) \\
(0.86) \\
(0.86)\end{array}$ \\
\hline
\end{tabular}

Difficulties Perceived by Superintendents in Working with Their Boards

Current superintendents were asked on question number 16 of the questionnaire what caused them the greatest difficulty in dealing with their boards. Knowledge of board/superintendent roles $(24 \%)$, board member longevity and experience (23\%), and not enough time devoted by the board to their roles as board members $(6 \%)$, constitute over half 
of the responses to this question. All these categories can be broadly categorized as "board member expertise." It appears that board members need some kind of training concerning their responsibilities as a board members before they assume office (see Table 5).

Table 5

Difficulties Perceived by Superintendents in working with Their School Board

\begin{tabular}{lrc}
\hline Difficulty & $f$ & f \\
\hline No problems with board relations & 36 & 31.03 \\
Knowledge of board/superintendent roles & 28 & 24.14 \\
Board longevity and experience & 27 & 23.28 \\
Not enough time devoted by board & 7 & 6.03 \\
Decisiveness on the board & 2 & 1.72 \\
Board's understanding of finances & 6 & 5.17 \\
Board relationship with the staff & 4 & 3.45 \\
Communication with the board & 4 & 3.45 \\
Problems with community relations & 1 & 0.86 \\
House Bill 3565* & 1 & 0.86
\end{tabular}

*oregon Educational Act for the 21st Century (1991)

Current superintendents

Data were collected on the current superintendents in the responding districts. The information gathered was divided into the three categories for further analysis: length of service in the current district, previous experience, and job satisfaction. 


\section{Length of Service}

The mean length of service for current superintendents involved in this study was slightly under five years ( 58 months), with a range from one month to 246 months. Superintendents who had held their position for one year or less accounted for $24 \%$ of the current superintendents, while $47 \%$ of the superintendents had been in their current positions for three or less years; $91 \%$ had less than eight years of seniority (see Table 6).

Adjusted Months represent a subtraction of two months from the total months given by respondents. This adjustment was made to more clearly reflect the actual number of months (years) in service of the respondents at the time they received the questionnaire which corresponded to the end of the standard contract year.

\section{Previous Experience}

The prevalent career path of current superintendents was through lane administrative positions; $44 \%$ reported that they were superintendents or assistant superintendents in other districts prior to assuming their current position. Table 7 shows that an additional $32 \%$ came from a principal or vice principal position. The prevalent career path for these superintendents appears to be through line administrative positions. Less than $25 \%$ were in other central office positions or teaching before assuming the office of chief executive officer in a district. For the 
purposes of grouping, "teacher" included those who had university/college positions prior to becoming a superintendent.

Table 6

Number of Months in Office of Current Superintendents

\begin{tabular}{|c|c|c|c|c|c|c|c|}
\hline $\begin{array}{l}\text { \# of } \\
\text { Months }\end{array}$ & $\underline{\underline{f}}$ & $\mathrm{p}$ & $\underline{C P}$ & $\begin{array}{l}\text { Adjusted } \\
\text { Months }\end{array}$ & $\underline{\underline{f}}$ & p & $\underline{\mathrm{CP}}$ \\
\hline $\begin{array}{r}193-246 \\
163-192 \\
157-162 \\
151-156 \\
145-150 \\
139-144 \\
133-138 \\
127-132 \\
121-126 \\
115-120 \\
109-114 \\
103-108 \\
97-102 \\
91-96 \\
85-90 \\
79-84 \\
73-78 \\
67-72 \\
61-66 \\
55-60 \\
50-54 \\
43-48 \\
37-42 \\
31-36 \\
25-30 \\
19-24 \\
13-18 \\
7-12 \\
0-6\end{array}$ & $\begin{array}{r}2 \\
3 \\
0 \\
1 \\
1 \\
1 \\
2 \\
1 \\
0 \\
2 \\
0 \\
1 \\
0 \\
10 \\
3 \\
4 \\
1 \\
7 \\
3 \\
12 \\
8 \\
0 \\
10 \\
3 \\
12 \\
2 \\
16 \\
0 \\
14\end{array}$ & $\begin{array}{r}1.72 \\
2.59 \\
0.00 \\
0.86 \\
1.72 \\
0.86 \\
1.72 \\
0.86 \\
0.00 \\
1.72 \\
0.00 \\
0.86 \\
0.00 \\
8.62 \\
2.58 \\
3.45 \\
0.86 \\
6.03 \\
2.58 \\
10.34 \\
6.90 \\
0.00 \\
8.62 \\
2.58 \\
10.34 \\
1.72 \\
13.79 \\
0.00 \\
12.07\end{array}$ & $\begin{array}{r}103.39 \\
101.67 \\
99.08 \\
99.08 \\
98.22 \\
96.50 \\
95.64 \\
93.92 \\
93.06 \\
93.06 \\
91.34 \\
91.34 \\
90.48 \\
90.48 \\
81.86 \\
79.28 \\
75.83 \\
74.97 \\
68.94 \\
66.36 \\
56.02 \\
49.12 \\
49.12 \\
40.50 \\
37.92 \\
27.58 \\
25.86 \\
12.07 \\
12.07\end{array}$ & $\begin{array}{r}193-246 \\
163-192 \\
157-162 \\
151-156 \\
145-150 \\
139-144 \\
133-138 \\
127-132 \\
121-126 \\
115-120 \\
109-114 \\
103-108 \\
97-102 \\
91-96 \\
85-90 \\
79-84 \\
73-78 \\
67-72 \\
61-66 \\
55-60 \\
50-54 \\
43-48 \\
37-42 \\
31-36 \\
25-30 \\
19-24 \\
13-18 \\
7-12 \\
0-6\end{array}$ & $\begin{array}{r}2 \\
3 \\
1 \\
2 \\
0 \\
3 \\
0 \\
1 \\
0 \\
2 \\
0 \\
1 \\
1 \\
10 \\
6 \\
4 \\
2 \\
6 \\
0 \\
14 \\
2 \\
7 \\
1 \\
12 \\
0 \\
13 \\
1 \\
15 \\
13\end{array}$ & $\begin{array}{r}1.72 \\
2.59 \\
0.86 \\
1.72 \\
0.00 \\
2.58 \\
0.00 \\
0.86 \\
0.00 \\
1.72 \\
0.00 \\
0.86 \\
0.86 \\
8.62 \\
5.17 \\
3.45 \\
1.72 \\
5.17 \\
0.00 \\
12.07 \\
1.72 \\
6.03 \\
0.86 \\
10.34 \\
0.00 \\
11.21 \\
0.86 \\
12.93 \\
11.21\end{array}$ & $\begin{array}{r}105.13 \\
103.41 \\
100.82 \\
99.96 \\
98.24 \\
98.24 \\
95.66 \\
95.66 \\
94.80 \\
94.80 \\
93.08 \\
93.08 \\
92.22 \\
91.36 \\
82.74 \\
77.57 \\
74.12 \\
72.40 \\
67.23 \\
67.23 \\
55.16 \\
53.44 \\
47.41 \\
46.55 \\
36.21 \\
36.21 \\
25.0 \\
24.14 \\
11.21\end{array}$ \\
\hline
\end{tabular}

NOTE: Adjusted months represent an adjustment of two months from the total of months given by respondents. Cumulative percentages are greater than $100 \%$ due to rounding up of individual percentages. 
Table 7

Measure of Frequency and Percentage

of Previous Position

\begin{tabular}{llc}
\hline Position & $\underline{f}$ & o \\
\hline Superintendent/Assistant Superintendent & 51 & 43.97 \\
Principal/Vice Principal & 37 & 31.90 \\
Central Office/Director & 15 & 12.93 \\
Teacher & 13 & 11.21 \\
\hline
\end{tabular}

\section{Job Satisfaction}

The questionnaire asked current superintendents whether they were satisfied with their current position. While the question could have been answered by a "yes" or "no" many superintendents made comments concerning their satisfaction. Whenever comments were added to this question, there appeared to be some emotion surrounding the remarks. Examples of comments made are; "Just started!!" or "YES!" A similar display of emotion was shown with negative responses as well; "NO!"

A majority of current superintendents ( $84 \%)$, reported that they were satisfied with their positions. Current superintendents whose prior experience was at the central office level, due to their physical proximity to the decision making structure of the school district, may have a different perspective of the role of the superintendent from those who came to the superintendency directly from the building level. This differential experience could 
influence job satisfaction. To examine this possibility, the categories of superintendent and assistant superintendent were added to central office (directors) and compared to principal/vice principal and teacher categories. A chi-square test of independence was performed on this data (chi-square $=0.733, \underline{\mathrm{df}}=1$, and $\underline{p}=.392)$. The statistical hypothesis that job satisfaction and previous position are independent was not rejected (see Table 8 ).

\section{Table 8}

Frequency and Percentage of Previous Position and Satisfaction with current Position as superintendent

Position

$\frac{\text { Satisfied }}{\underline{f}} \quad \frac{\text { Dissatisfied }}{\underline{f}}$

Superintendent/Assistant Supt. Principal/Vice Principal Central office/Director Teacher

$\begin{array}{lllr}43 & 84.31 & 8 & 15.69 \\ 28 & 75.68 & 9 & 24.32 \\ 14 & 93.33 & 1 & 6.67 \\ 12 & 92.31 & 1 & 7.69\end{array}$

NOTE: Chi-square $=0.733, \underline{d f}=1$, and $\underline{p}=.392$.

Although not examined by this study, it is likely that experience in a "line" administrative position could impact the job satisfaction of a new superintendent. A second analysis was conducted by grouping all categories that represent line administration (superintendent, assistant superintendent, principal and vice principal) against those positions that are considered staff positions (central office, director, and teacher). A chi-square test of 
independence was conducted on this data (chi-square $=2.299$, $\underline{\mathrm{df}}=1$, and $\mathrm{p}=.129)$. The statistical hypothesis that the superintendent's previous position and current job satisfaction are independent was not rejected.

The satisfaction of current superintendents with their boards may be dependent on the mean years of service of the board. To obtain adequate cell frequencies in all cells, years of service was partitioned into two groups, zero to five years and over five years. A chi-square test of independence was conducted on this data (chi-square $=.338$, $\underline{d f}=1$, and $\underline{p}=.561$ ). The / statistical hypothesis that the number of years of service of board members and superintendent satisfaction are independent was rejected. No statistical significance between the average number of years of service of members of the board and superintendent satisfaction in his/her position was found (see Table 9). The result of the chi-square statistical analysis of the hypothesis that years of service and superintendent satisfaction are independent was not rejected. There does not appear to be a link between years of service and superintendent satisfaction.

Whether there was an interim superintendent made little difference with superintendents who are not currently satisfied. A difference in the satisfaction with their current position was disclosed with superintendents who are satisfied with their current job. A majority, 66 (68\%), 
expressed satisfaction not following an interim while 31 (32\%) expressed satisfaction following an interim superintendent. It may therefore be stated that the current superintendent is more likely to be satisfied if he/she is able to assume the superintendency directly after his/her predecessor. No statistical significance was found (see Tables 10 and 11).

Table 9

Superintendent Satisfaction and Board Member Years of Service

\begin{tabular}{|c|c|c|c|c|}
\hline \multirow{3}{*}{$\begin{array}{l}\text { Average Years } \\
\text { of Service } \\
0-5 \\
\text { Over } 5\end{array}$} & \multicolumn{2}{|c|}{ Satisfied } & \multicolumn{2}{|c|}{ Dissatisfied } \\
\hline & $\underline{\underline{f}}$ & $\frac{8}{6}$ & $\underline{\underline{f}}$ & $\frac{9}{6}$ \\
\hline & $\begin{array}{l}53 \\
44\end{array}$ & $\begin{array}{l}85.46 \\
74.07\end{array}$ & $\begin{array}{r}9 \\
10\end{array}$ & $\begin{array}{l}14.51 \\
13.52\end{array}$ \\
\hline
\end{tabular}

Table 10

Measure of Frequency and Percentage

for Interim Superintendents

\begin{tabular}{lcc}
\hline Interim Superintendents & $\underline{f}$ & \\
\hline Yes & 39 & 33.62 \\
No & 77 & 66.38 \\
Total & 11 & 6100 \\
NOTE: Chi-square $=.733, \underline{\mathrm{df}}=1$, and $\mathrm{p}=.392$. &
\end{tabular}


Table 11

Measure of the Number of Months of Interim superintendency

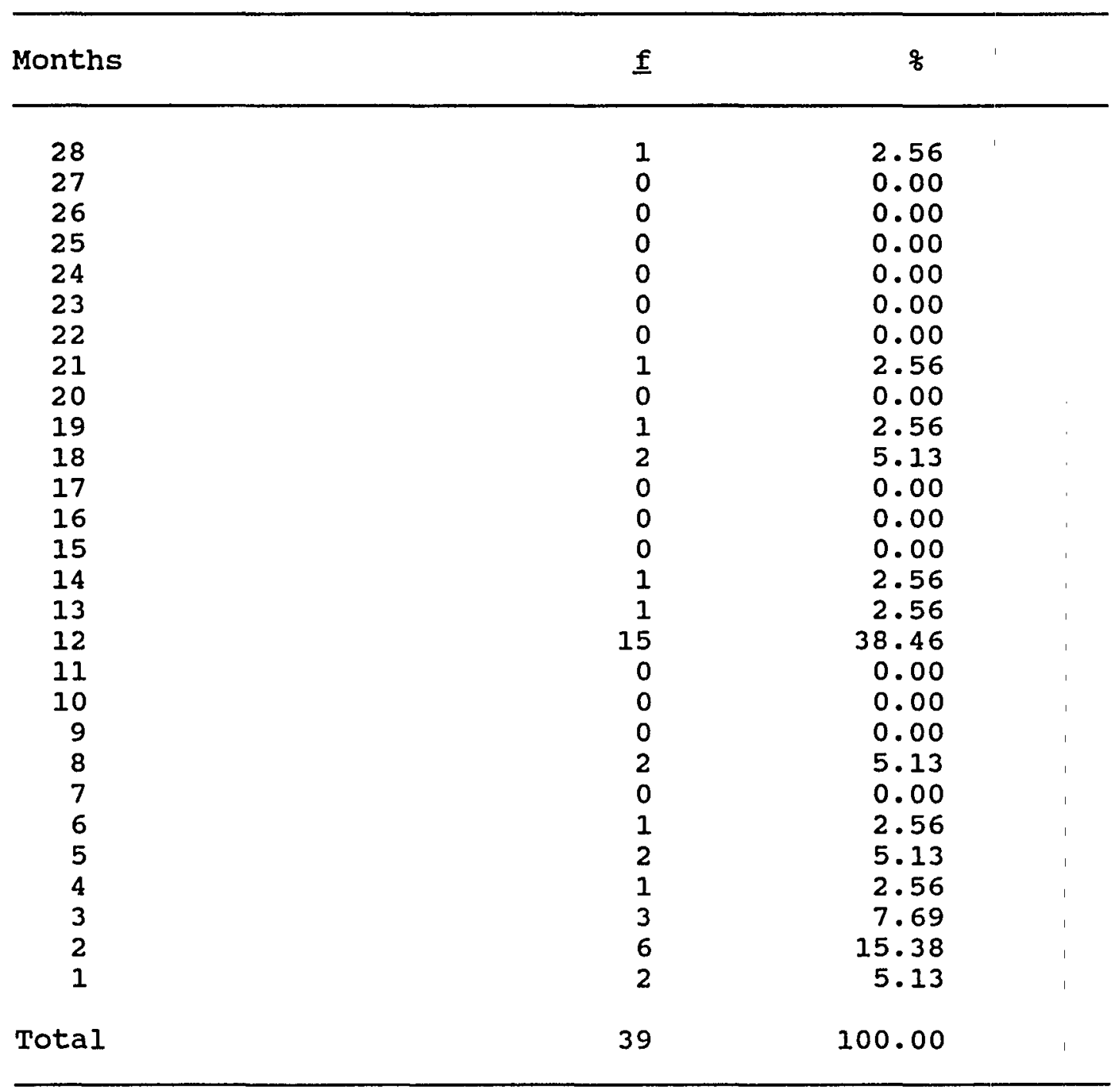

It is interesting that 34 superintendents retired from districts without meeting Public Employees Retirement system (PERS) requirements while 43 superintendents retired meeting PERS requirements. Analysis of these numbers would lead to the conclusion that those who retired meeting PERS 
requirements are represented by the "odd" numbered responses in that retirement dates are calculated six months after initial hire. Generally speaking, those districts in which a the superintendent retired meeting PERS requisites should be reflected by months of interim superintendency either under one year or over one year because of the method of establishing retirement dates, whereas those districts in which the superintendent retired without meeting PERS requirements should be reflected by an even number of months of interim superintendency.

Turnover Rate

The first research question pertained to the turnover rates in the past five years for:

a. superintendents.

b. incumbent board members.

c. superintendents when an incumbent board member failed to be reelected.

For the purposes of this discussion, turnover will mean that a vacancy occurred in the office of superintendent or on the board of directors. Table 12 shows that 70 vacancies occurred in the superintendency out of a possible 116 during the past five years. This means that the turnover rate for superintendents in the 116 districts studies was $60 \%$ during the past five years. The data also indicates that there were 631 board member openings during the five-year period 
under study. of the total number of openings, 446 (71\%) were contested elections with 285 (64\%) resulting in incumbent defeat. The turnover rate for incumbent board members in contested elections was $64 \%$ (see Table 12).

Table 12

Turnover Rate

\begin{tabular}{|c|c|c|c|c|c|}
\hline \multirow[t]{2}{*}{ Position } & \multirow{2}{*}{$\frac{\text { Total Possible }}{\text { Change }} \underset{\underline{f}}{ }$} & \multicolumn{2}{|c|}{$\frac{\text { Contested Board }}{\text { Elections }}$} & \multicolumn{2}{|c|}{ Turnover } \\
\hline & & $\underline{\underline{E}}$ & $\frac{9}{6}$ & $\underline{f}$ & 8 \\
\hline $\begin{array}{l}\text { Superintendent } \\
\text { Board Member }\end{array}$ & $\begin{array}{l}116 \\
631\end{array}$ & 446 & 70.86 & $\begin{array}{r}70 \\
285\end{array}$ & $\begin{array}{l}60.34 \\
63.90\end{array}$ \\
\hline
\end{tabular}

There were 100 board member openings reported as members who chose not to stand for reelection. There was no method for determining if these openings resulted in either contested or uncontested elections. They did however result in board member turnover. The addition of these openings creates a turnover rate of $61 \%$. There were three recall elections reported. If the recall elections are included as contested elections the total number of contested elections becomes 449 (61.51\%) and the corresponding number of turnovers could become $384(52.60 \%)$ depending on the outcome of the elections. 
Board Member Turnover

The second question proposed by this study concerned the factors associated with board member turnover. In examining this question, three areas were studied. They were, the law, the frequency of turnover, and the factors associated with the turnovers.

The Law and Board Member

openings

Oregon Election Law (cited in Oregon Department of Education, 1991) provides terms of office for board membership of four years. Membership is staggered so that the maximum number of members elected in any single election should be two. There is no legal limit to the number of times a member may run and be elected to the board.

Excluding elections to fill unexpired terms and using the staggered term, the maximum expected total number of openings on the 116 boards would be 712 . The minimum expected total number of openings would be the sum of having all five members stand for election once during the fiveyear period studied, or 580 openings. The 630 openings reported fall within the expected range.

There was, however, a wide range of reported vacancies in individual districts from zero to 16 . In 16 districts there were board members who did not complete their terms. There may have been appointments made to fill the unexpired time remaining in those districts. This would account for a 
number greater than the maximum expected total number of possible elections. In 31 districts the number of reported openings was less than the expected total. This may have been a result of boards reappointing existing members to one or more additional terms. The mean of board membership openings was 5.28 per responding district. Table 13 is a graphic representation of the frequency of board openings by districts.

As stated earlier in this study, oregon has implemented a Consolidation Law (cited in oregon Department of Education, 1991) which requires all districts to be Union High School Districts by 1996. The researcher suspected that since consolidation normally occurs in July, at the end of the fiscal year, board members who were due for election in the preceding March election were appointed by the board to serve until consolidation took place. Discussion by telephone (K. Murdock, May 1994) with the oregon Department of Education (legal section) revealed that, while this was a possibility, it is/was not legal and that the oregon Department of Education had no knowledge of this taking place. Board appointments of this nature would conserve district financial resources and provide for board continuity. It is difficult to accept the concept that these types of appointments do not constitute a second reason for the reported number of elections being fewer than the maximum expected number. 
Table 13

Frequency of Board Member Openings

\begin{tabular}{ccc}
\hline Number of Openings & $\underline{\underline{f}}$ & \\
\hline 16 & 1 & 0.86 \\
15 & 0 & 0.00 \\
14 & 0 & 0.00 \\
13 & 1 & 0.86 \\
12 & 1 & 0.86 \\
11 & 0 & 0.00 \\
10 & 1 & 0.86 \\
9 & 5 & 4.31 \\
8 & 7 & 6.03 \\
-7 & --14 & 12.07 \\
6 & 18 & 15.52 \\
5 & 37 & 4.31 \\
\hline 4 & ---10 & 8.62 \\
3 & 10 & 8.62 \\
2 & 7 & 6.03 \\
1 & 4 & 3.45
\end{tabular}

NOTE: The dashed line represents grouping used in comparing these data with other factors discussed later in the chapter.

\section{Frequency of Turnover}

There were 631 reported openings on the 116 boards studied (see Table 12). The average number of openings on a given board was five. There are three reasons for board member turnovers. They may: (a) resign their position (or die in office), (b) be recalled through an election process, or (c) be defeated in reelection attempts. Positions on school boards in oregon are elected, political positions. They are unpaid and therefore voluntary. A member may resign at any time during his/her term. The average length 
of service for board members in this study was slightly over five years.

Table 14

Years of Service for Board Members

Mean Years of Service Numbers of Board's Directors

10
9
8
7
6
5
4
3
2
1


Table 15

Changes in Board Membership

\begin{tabular}{crc} 
Number of Changes & $\underline{f}$ & \\
\hline & & \\
7 & 1 & 0.86 \\
7 & 2 & 1.72 \\
5 & 1 & 0.86 \\
4 & 1 & 0.86 \\
3 & 4 & 3.45 \\
2 & 5 & 4.31 \\
1 & 12 & 10.34 \\
0 & 29 & 25.00 \\
& 61 & 52.59
\end{tabular}

NOTE: Breaks between one and two, and four and five are inserted for statistical purposes later in this chapter.

As may be seen in the table, over one half, (53\%) of the responding districts reported no change in board membership during the five-year period. An additional $25 \%$ of the districts reported one change in membership. Having $78 \%$ of the responding districts with one or fewer changes in board membership in a five-year period reflects an unexpected stability on boards during this period of district consolidation and tał limitations.

\section{Factors Associated with Board Member Turnover}

The second research question concerned those factors that might be related to board member turnover. The mean years of service for board members in the studied districts during the five-year period of study was 5.2 years. Defeat 
in an election accounted for $74 \%$ of board member turnover. However, $26 \%$ of board members chose not to run for reelection (see Table 16).

Table 16

Reasons for Board Member Turnover

\begin{tabular}{lrrc} 
Reason & $\underline{f}$ & of of change & of of total \\
\hline Was defeated in election & 284 & 73.96 & 45.01 \\
Chose not to stand & 100 & 26.04 & 15.85 \\
Had served multiple terms & 48 & $(48.0)$ & \\
Children no longer in school & 17 & $(17.0)$ & \\
Moved out of district & 12 & $(12.0)$ & \\
Dissatisfied with schools & 9 & $(9.0)$ & \\
Personal or family health & 6 & $(6.0)$ & \\
Felt that defeat was imminent & 5 & $(5.0)$ & \\
Was recalled & 3 & $(3.0)$ &
\end{tabular}

NOTE: The questionnaire did not gather specific data on board member resignations, it did gather data on reasons for members not standing for reelection. Values in parentheses are percentages of those not standing for reelection.

There were 100 board members who chose not to seek reelection. As might be expected, the most frequently reported reason for this choice was that the members had served multiple terms (48\%). The next most common reason was a perceived disassociation from the schools, with 13 members relocating and 13 members stating that they no longer had children involved in the schools (26\%). When all of the categories that could be considered as negative reasons for not seeking reelection are combined, (defeat was imminent, recalled, and dissatisfied with the schools), only 
10 members were involved. Recall represented only $3 \%$ of the respondents' reasons for not seeking reelection. That percentage decreases appreciably when the entire 631 openings across the districts are considered. Recall was not a significant factor in board members' decisions not to stand for reelection. The data suggest that the majority of board members were satisfied with their role as board members while serving. Board members gave non-negative reasons for not standing for reelection in 74 (84\%) cases and negative reasons in only 14 (16\%) cases including those mentioned above.

It should be noted that reasons appearing non-negative or conversely negative could be interpreted opposite from the interpretation given here. For example, "relocation" could be accomplished for the negative reason of the candidate's desire to deliberately move out of the school district and "multiple terms" could mean that the board member was "burned out" with the district. The researcher chose to interpret these responses as was done because other, more explicitly negative or positive options were available to the respondent in the questionnaire. The stated reasons for not seeking reelection are listed in Table 17. As was expected, over $50 \%$ of the members not seeking reelection gave the reason for not standing for reelection as having served multiple terms. Very small percentages were due to either recall (3\%) or 
dissatisfaction with the schools $(2 \%)$. I It is safe to assume that given this data, most members are satisfied as school board members. This interpretation is supported by the numbers of members who stood for reelection. There were six times the number of incumbents who chose to stand for reelection as opposed to those who declined to do so. The sum of the positions elected from incumbents, defeated, and those not choosing to stand for reelection is 14 less than the total of 631. The data from other areas in this chapter suggests that this apparent discrepancy is due to boards making appointments to fill vacancies as they occurred. The appointment of members to the various boards does not alter the apparent fact that as the number of elections increases, so does the number of contests. This is particularly true when the number of elections rises beyond that of the expected number of elections.

Changes in Board Membership and superintendent Turnover

As shown in Table 12 there were 631 board positions open for election in the 116 studied districts during the five-year period under study; 70 of these districts had vacancies in the office of the superintendent. Table 17 displays the data concerning board openings by turnover in the office of the superintendent. 
Table 17

Frequency of Board Elections and Superintendent Turnover

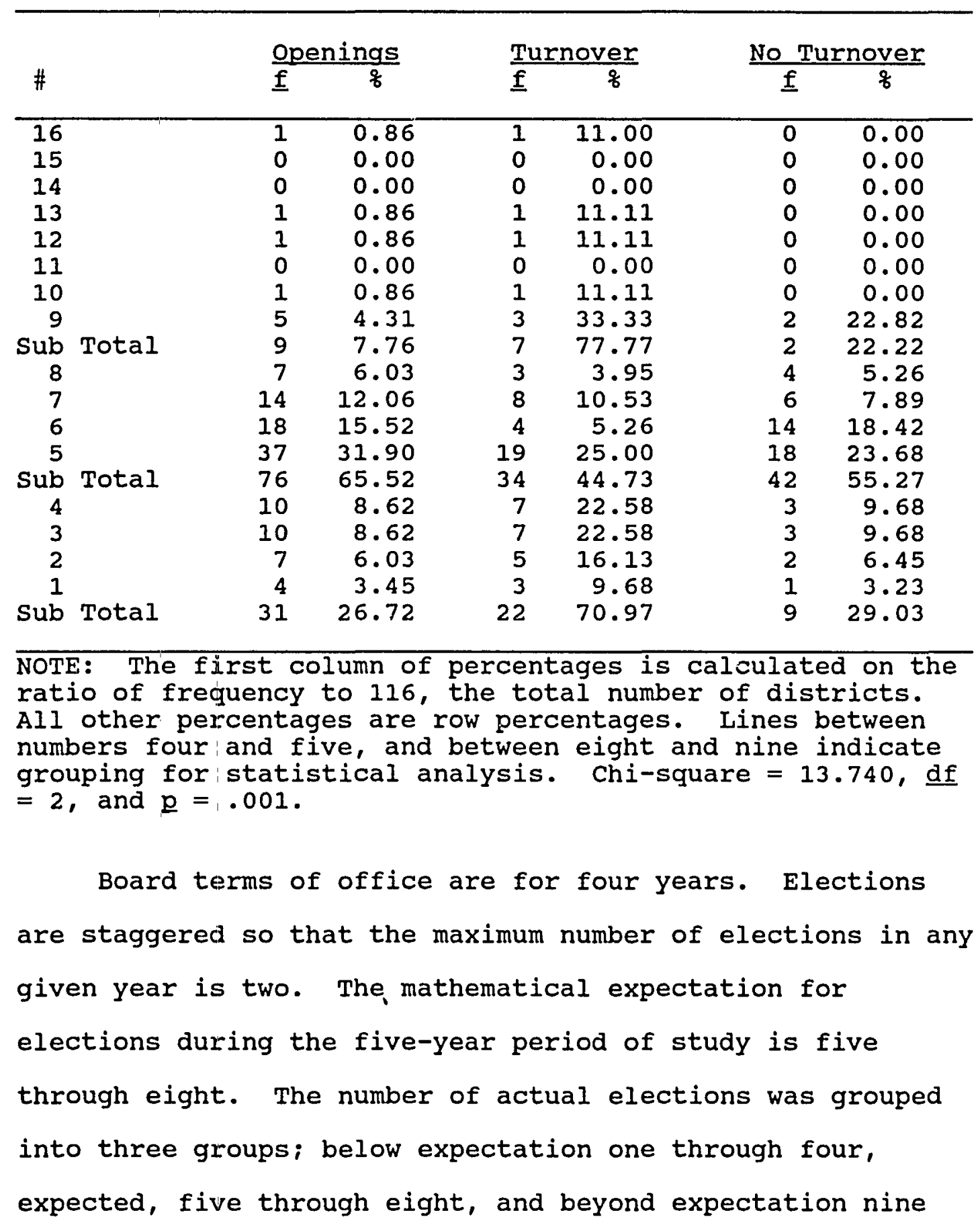


through 16. A chi-square test of independence was performed on the data using this grouping (chi-square $=13.740$, df $=$ 2 , and $\underline{p}=.001)$. The statistical hypothesis that the number of bolard elections and superintendent turnover are independent was rejected. It is interesting to note that the ratio of superintendent turnover is higher in both the above and the below expectation groups than it is in the expected group.

Board Relationship with the Superintendent

It should be noted that current superintendents were reporting on their predecessor and that the current superintendents were not limited to the five-year period of the study in making their responses. Table 18 shows the data gathered from the questionnaire with regard to the relationship| the previous superintendent had with his/her board and the frequency of board elections. Over half, 58\%, of board elections took place in districts in which the relationship|between the board and the superintendent was described as। poor or bad. The majority of those elections took place in the expected range of elections, five to eight. The expected frequencies in some cells were too small to allow for a statistical analysis of the data. 
Table 18

Frequency of Elections and Board Relationship with the superintendent

\begin{tabular}{|c|c|c|c|c|c|c|c|c|}
\hline $\begin{array}{l}\text { Relations } \\
\# \text { of }\end{array}$ & Exce & ellent & & Good & & Poor & & $\mathrm{Bad}$ \\
\hline Elections & $\underline{\underline{f}}$ & $\frac{9}{6}$ & $\underline{\underline{f}}$ & $q$ & $\underline{\underline{f}}$ & $\frac{8}{8}$ & $\underline{\underline{f}}$ & 8 \\
\hline $\begin{array}{c}16 \\
15 \\
14 \\
13 \\
12 \\
11 \\
10 \\
9 \\
\text { Sub Total }\end{array}$ & $\begin{array}{l}1 \\
0 \\
0 \\
0 \\
1 \\
0 \\
0 \\
1 \\
3\end{array}$ & $\begin{array}{l}3.85 \\
0.00 \\
0.00 \\
0.00 \\
3.85 \\
0.00 \\
0.00 \\
3.85 \\
2.59\end{array}$ & $\begin{array}{l}0 \\
0 \\
0 \\
1 \\
0 \\
0 \\
1 \\
0 \\
2\end{array}$ & $\begin{array}{l}0.00 \\
0.00 \\
0.00 \\
4.55 \\
0.00 \\
0.00 \\
4.55 \\
0.00 \\
1.72\end{array}$ & $\begin{array}{l}0 \\
0 \\
0 \\
0 \\
0 \\
0 \\
0 \\
3 \\
3\end{array}$ & $\begin{array}{l}0.00 \\
0.00 \\
0.00 \\
0.00 \\
0.00 \\
0.00 \\
0.00 \\
6.38 \\
2.59\end{array}$ & $\begin{array}{l}0 \\
0 \\
0 \\
0 \\
0 \\
0 \\
0 \\
1 \\
1\end{array}$ & $\begin{array}{l}0.00 \\
0.00 \\
0.00 \\
0.00 \\
0.00 \\
0.00 \\
0.00 \\
4.76 \\
.86\end{array}$ \\
\hline $\begin{array}{c}8 \\
7 \\
6 \\
5 \\
\text { Sub Total }\end{array}$ & $\begin{array}{r}2 \\
1 \\
8 \\
8 \\
19\end{array}$ & $\begin{array}{r}7.69 \\
3.85 \\
30.77 \\
30.77 \\
16.38\end{array}$ & $\begin{array}{r}0 \\
4 \\
1 \\
62 \\
11\end{array}$ & $\begin{array}{r}0.00 \\
18.18 \\
4.55 \\
7.27 \\
9.48\end{array}$ & $\begin{array}{r}3 \\
6 \\
6 \\
17 \\
32\end{array}$ & $\begin{array}{r}6.38 \\
12.77 \\
12.77 \\
36.17 \\
27.59\end{array}$ & $\begin{array}{r}2 \\
31 \\
31 \\
62 \\
14\end{array}$ & $\begin{array}{r}9.52 \\
4.29 \\
4.29 \\
8.57 \\
12.07\end{array}$ \\
\hline $\begin{array}{c}4 \\
3 \\
2 \\
1 \\
\text { Sub Total }\end{array}$ & $\begin{array}{l}1 \\
2 \\
0 \\
1 \\
4\end{array}$ & $\begin{array}{l}3.85 \\
7.69 \\
0.00 \\
3.85 \\
3.45\end{array}$ & $\begin{array}{r}31 \\
2 \\
3 \\
1 \\
9\end{array}$ & $\begin{array}{r}3.64 \\
9.10 \\
13.64 \\
4.55 \\
7.76\end{array}$ & $\begin{array}{r}61 \\
3 \\
2 \\
1 \\
12\end{array}$ & $\begin{array}{r}2.77 \\
6.38 \\
4.26 \\
2.13 \\
10.34\end{array}$ & $\begin{array}{l}0 \\
3 \\
2 \\
1 \\
6\end{array}$ & $\begin{array}{r}0.00 \\
14.29 \\
9.52 \\
4.76 \\
5.17\end{array}$ \\
\hline TOTAL & 26 & 22.41 & 22 & 18.97 & 478 & 40.52 & 21 & 18.10 \\
\hline
\end{tabular}

A second question on the questionnaire dealt with the amount of opposition that the current superintendent felt his/her predecessor faced on the board. The responses on this question were not limited to the five-year period of the study, but were responses based on what opposition on the board the current superintendent felt his/her predecessor faced at the time he/she left office. It is of 
interest to note that $44 \%$ of the superintendents were in good standing with their boards and that the largest single percentage of elections (30\%) took place in the expected frequency range. statistical analysis of the data was not possible due to lower than expected frequencies in some cells (see Table 19).

Table 19

Frequency of Elections and Board Opposition to the Superintendent

\begin{tabular}{|c|c|c|c|c|c|c|}
\hline \multirow{2}{*}{$\begin{array}{l}\text { Opposition } \\
\text { \# of Elections }\end{array}$} & \multicolumn{2}{|c|}{ Good } & \multicolumn{2}{|c|}{$\begin{array}{l}\text { Opposed by } \\
\text { Minority }\end{array}$} & \multicolumn{2}{|c|}{$\begin{array}{l}\text { Opposed by } \\
\text { Majority }\end{array}$} \\
\hline & $\underline{f}$ & $\frac{8}{6}$ & $\underline{\mathbf{f}}$ & $\frac{q}{8}$ & $\underline{\underline{f}}$ & 8 \\
\hline $\begin{array}{c}16 \\
15 \\
14 \\
13 \\
12 \\
11 \\
10 \\
9 \\
\text { Sub Total }\end{array}$ & $\begin{array}{l}0 \\
0 \\
0 \\
0 \\
0 \\
0 \\
0 \\
4 \\
4\end{array}$ & $\begin{array}{l}0.00 \\
0.00 \\
0.00 \\
0.00 \\
0.00 \\
0.00 \\
0.00 \\
7.84 \\
3.45\end{array}$ & $\begin{array}{l}0 \\
0 \\
0 \\
0 \\
0 \\
0 \\
0 \\
0 \\
0\end{array}$ & $\begin{array}{l}0.00 \\
0.00 \\
0.00 \\
0.00 \\
0.00 \\
0.00 \\
0.00 \\
0.00 \\
0.00\end{array}$ & $\begin{array}{l}1 \\
0 \\
0 \\
1 \\
1 \\
0 \\
1 \\
1 \\
5\end{array}$ & $\begin{array}{l}2.22 \\
0.00 \\
0.00 \\
2.22 \\
2.22 \\
0.00 \\
2.22 \\
2.22 \\
4.31\end{array}$ \\
\hline $\begin{array}{c}8 \\
7 \\
6 \\
5 \\
\text { Sub Total }\end{array}$ & $\begin{array}{r}2 \\
6 \\
7 \\
20 \\
35\end{array}$ & $\begin{array}{r}3.92 \\
11.76 \\
13.73 \\
39.22 \\
30.17\end{array}$ & $\begin{array}{r}2 \\
3 \\
22 \\
5 \\
12\end{array}$ & $\begin{array}{r}10.00 \\
15.00 \\
0.00 \\
25.00 \\
10.34\end{array}$ & $\begin{array}{r}3 \\
5 \\
9 \\
12 \\
29\end{array}$ & $\begin{array}{r}6.67 \\
11.11 \\
20.00 \\
26.67 \\
25.00\end{array}$ \\
\hline $\begin{array}{c}4 \\
3 \\
2 \\
1 \\
\text { Sub Total }\end{array}$ & $\begin{array}{r}3 \\
6 \\
2 \\
1 \\
12\end{array}$ & $\begin{array}{r}5.88 \\
11.76 \\
3.92 \\
1.96 \\
10.34\end{array}$ & $\begin{array}{l}6 \\
1 \\
1 \\
0 \\
8\end{array}$ & $\begin{array}{r}30.00 \\
5.00 \\
5.00 \\
0.00 \\
6.90\end{array}$ & $\begin{array}{r}1 \\
3 \\
4 \\
3 \\
11\end{array}$ & $\begin{array}{l}2.00 \\
6.67 \\
8.89 \\
6.67 \\
9.48\end{array}$ \\
\hline TOTAL & 51 & 43.97 & 20 & 17.24 & 45 & 38.79 \\
\hline
\end{tabular}


Political Climate and Board

Member Turnover

Board membership is gained through the political process of election. Data were gathered concerning the political climate in the district and board member turnover. Table 20 presents the relationship between any turnover on the board and political climate. In over half, 60\%, of the districts with at least one board member change the climate was politically active. Further $60 \%$ of the total board elections occurred when the climate was active (see Table 21). A chi-square test of independence was performed on this data. The statistical hypothesis that board member turnover and political climate are independent was not rejected (chi-square $=.059, \underline{\mathrm{df}}=1$, and $\underline{\mathrm{p}}=.809$ ).

Table 20

Board Turnover and Political climate

\begin{tabular}{|c|c|c|c|c|}
\hline \multirow[b]{2}{*}{ Turnover } & \multicolumn{2}{|c|}{ Calm Climate } & \multicolumn{2}{|c|}{ Active Climate } \\
\hline & $\underline{f}$ & $q$ & $\underline{\underline{f}}$ & $\frac{q}{8}$ \\
\hline $\begin{array}{l}\text { Yes } \\
\text { No }\end{array}$ & $\begin{array}{r}35 \\
9\end{array}$ & $\begin{array}{l}40.23 \\
37.50\end{array}$ & $\begin{array}{l}52 \\
15\end{array}$ & $\begin{array}{l}59.77 \\
62.50\end{array}$ \\
\hline Total & 44 & 39.64 & 67 & 60.36 \\
\hline
\end{tabular}


Table 21

Frequency of Board Elections and Political climate

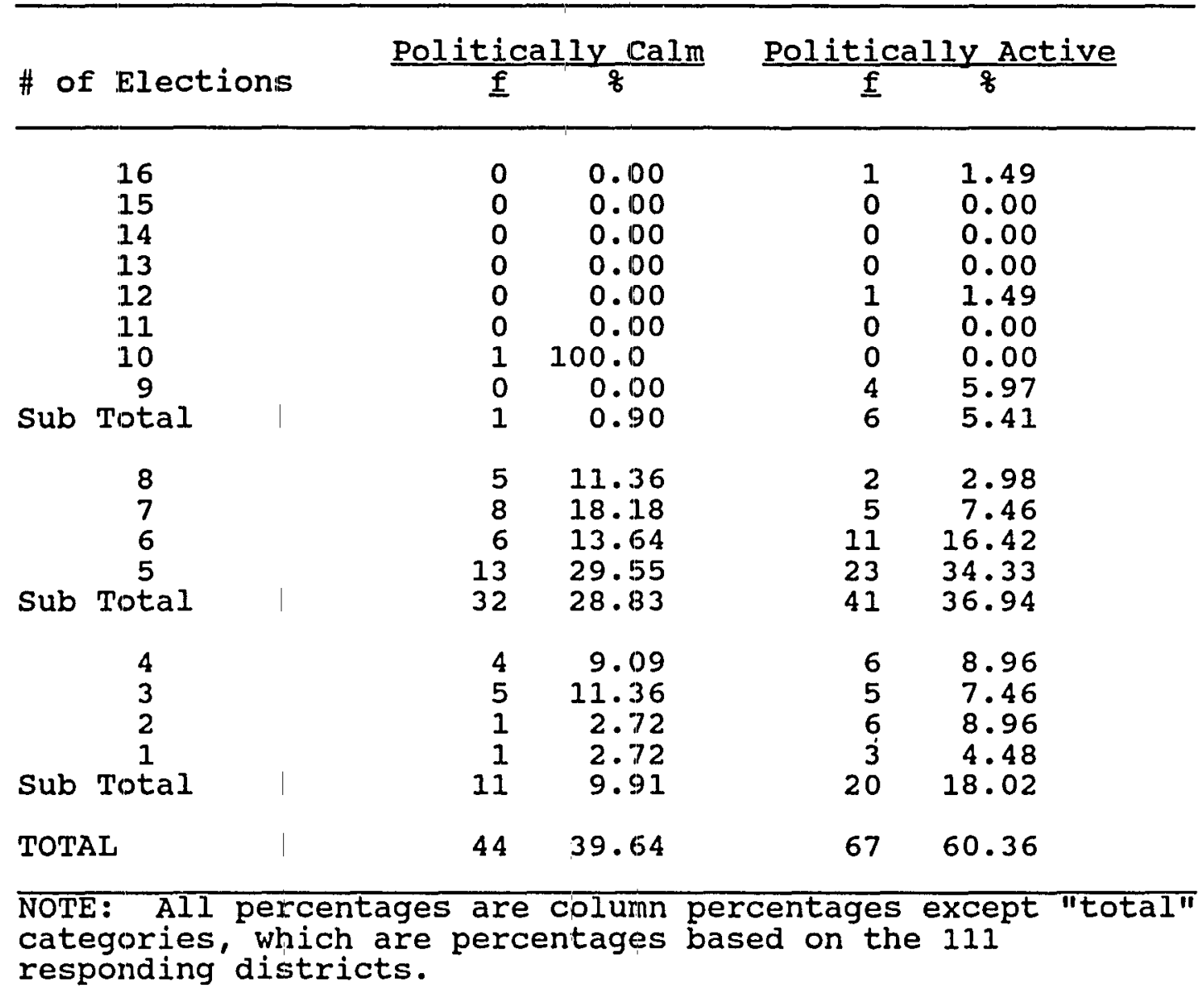

Table 22 shows that there appears to be little relation between members leaving the board and their relationship with the superintendent. However there is a discernible difference when the political climate is active, as opposed to calm, with $47 \%$ either being defeated or choosing not to stand for reelection while only $30 \%$ chose to leave the board during a period of political calm. 
Table 22

Board Member Turnover, Board Opposition, and Political. Climate

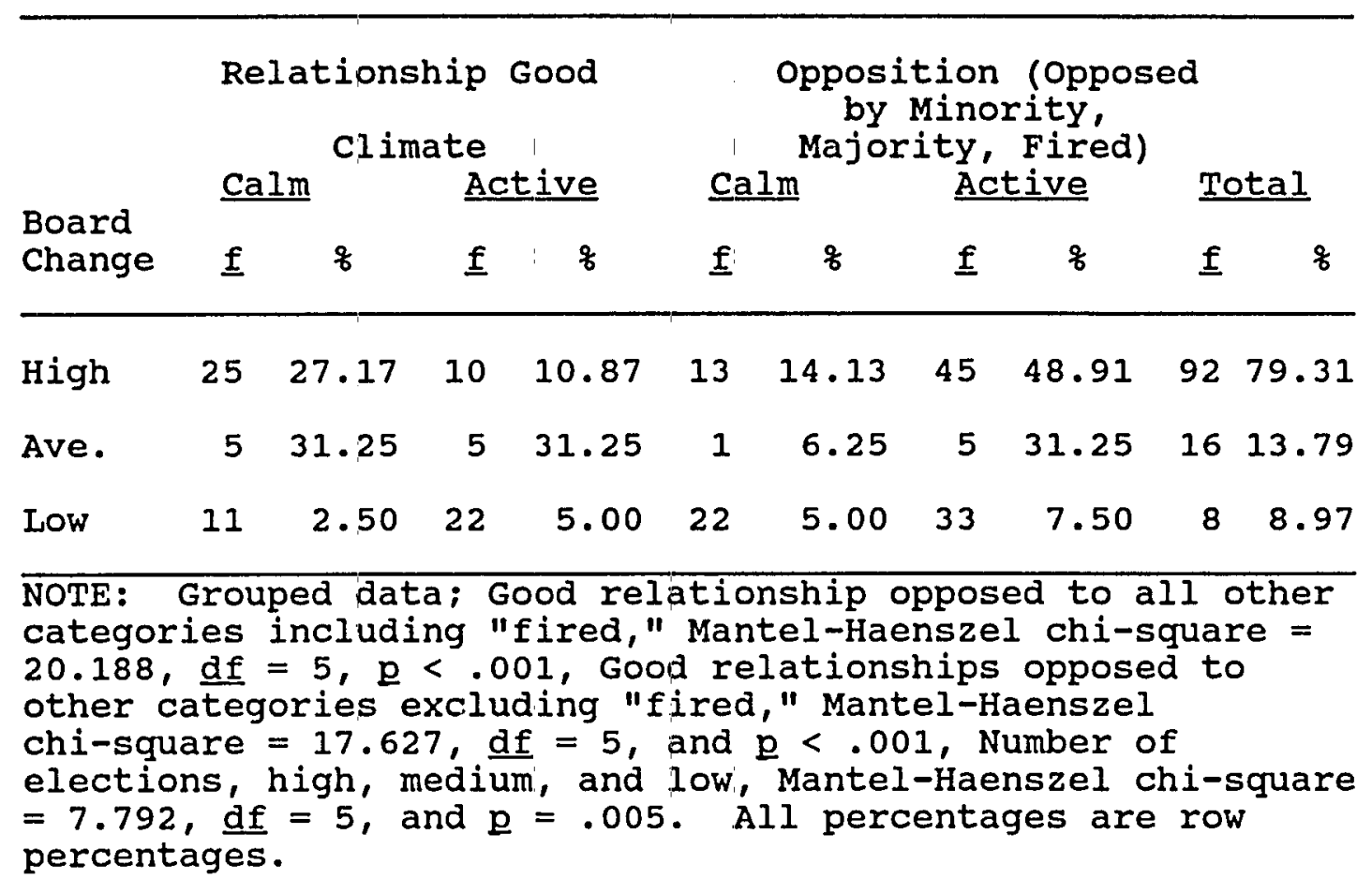

The data were grouped into three groups: high number of board turnovers (six to eight), medium number of board turnovers (three to five), and low number of board turnovers (one and two). A chi-square test of independence was performed on this data (Mantel-Haenszel chi-square $=7.792$, $\underline{\mathrm{df}}=5$, and $\mathrm{p}=.005)$. The statistical hypothesis that superintendent turnover, board relationship, and political climate are independent was rejected (chi-square $=7.792$, $\underline{\text { df }}$ $=5, \underline{\mathrm{g}}=.005)$. The statistical hypothesis that board member turnover, superintendent relationship, and political climate are independent was rejected. Turnover on the 
board, the relationship between the board and the superintendent, and political climate are not independent of each other.

Factors Related to superintendent Turnover

The third question posed by this study concerned factors which may be related to superintendent turnover. Four factors were chosen; changes in board membership, relationship with the board, political climate, and bond attempts.

Changes in Board Membership

of those districts with four or fewer elections, $71 \%$ had turnovers in the office of superintendent. In those districts with nine or more elections there was a $78 \%$ turnover. It is interesting to note that with those districts whose elections fall within the expected range, from five to eight elections, there was only a $45 \%$ turnover. It is also of interest that 31 districts conducted four or fewer elections. Oregon state law limits the term of office of board members to four years. The terms are staggered so that each year at least one board position is open, and two are open every other year. The law also stipulates that appointed members may only serve until the next election date in March at which time they must either be elected or be removed from the board (ORS 332, cited in oregon 
Department of Education, 1991). It is apparent that something was happening in these 31 districts that was beyond explanation under the law.

The number of board openings was categorized into three groups: one to four openings, five to eight openings, and nine to 16 openings. A chi-square test of independence was performed on this data (chi-square $=13.740, \underline{\mathrm{df}}=2$, and $\mathrm{p}=001)$. The statistical hypothesis that the number of board openings and superintendent turnover are independent was rejected. Therefore, when elections fall under or beyond the expected range, the rate of turnover in the office of superintendent is greatly increased.

There were 631 open positions on boards in the 116 districts surveyed with 449 of those openings involved in contested elections. of the contested elections, $74 \%$ resulted in the defeat of the incumbent board member (see Tables 11 and 17). The data displayed in Table 23 were obtained from responses to direct questions pertaining to elections, contested elections, and board turnover from the questionnaire. The data were grouped into two groups for statistical analysis: 0 to 4 contested elections and 5 through 12 contested elections. The groups were chosen based on an analysis of "expected" contested elections, zero to four, and beyond expectation, five through 12 elections. A chi-square test of independence was performed on the resulting data (chi-square $=9.074, \underline{\mathrm{df}}=1$, and $\mathrm{p}=.003$ ). 
Table 23

Contested Elections and Superintendent Turnover

\begin{tabular}{|c|c|c|c|c|c|c|}
\hline \multicolumn{3}{|c|}{ Contested Elections } & \multicolumn{2}{|c|}{ Turnover } & \multicolumn{2}{|c|}{ No Turnover } \\
\hline$\#$ & $\underline{f}$ & $\bar{q}$ & $\underline{\mathbf{f}}$ & $\bar{q}$ & $\underline{\mathbf{f}}$ & is \\
\hline 12 & 1 & 0.86 & 0 & 0.00 & 1 & 100 \\
\hline 11 & 1 & 0.86 & 1 & 100.00 & 0 & 0.00 \\
\hline 10 & 0 & 0.00 & 0 & 0.00 & 0 & 0.00 \\
\hline 9 & 0 & 0.00 & 0 & 0.00 & 0 & 0.00 \\
\hline 8 & 1 & 0.86 & 1 & 100.00 & 0 & 0.00 \\
\hline 7 & 5 & 4.31 & 2 & 40.00 & 3 & 60.00 \\
\hline 6 & 6 & 5.17 & 4 & 66.67 & 2 & 33.33 \\
\hline 5 & 15 & 12.93 & 7 & 46.67 & 8 & 53.33 \\
\hline Sub total & 29 & 25.00 & 15 & 51.72 & 14 & 48.28 \\
\hline 4 & 11 & 9.48 & 6 & 54.55 & 5 & 45.45 \\
\hline 3 & 12 & 10.35 & 8 & 66.67 & 4 & 33.33 \\
\hline 2 & 20 & 17.24 & 12 & 60.00 & 8 & 40.00 \\
\hline 1 & 28 & 24.14 & 18 & 64.29 & 10 & 35.71 \\
\hline 0 & 16 & 13.79 & 11 & 68.75 & 5 & 31.25 \\
\hline Sub total & 87 & 75.00 & 55 & 63.22 & 32 & 36.78 \\
\hline
\end{tabular}

NOTE: Data has been grouped into two groups, zero to four and five through 12 for the purposes of statistical analysis ( chi-square $=9.074, \underline{\mathrm{df}}=1$, and $\mathrm{p}=.003)$. The first column of percentages is computed on the total number of districts; all other percentages are row percentages.

The statistical hypothesis that the number off contested elections and superintendent turnover are independent was rejected. A second analysis of the data was performed comparing zero elections against all others (chi-square = $0.548, \underline{\mathrm{df}}=1$, and $\mathrm{p}=.459$ ). Again, the statistical hypothesis that the number of contested elections|and superintendent turnover are independent was rejected. It is interesting to note, however that the lower the number of contested elections, the higher the turnover rate for 
superintendents. Although the numbers are limited, the data suggest that the same is true for the highest numbers of contested elections and superintendent turnover. The middle number of contested elections (two through four) appears to offer the most stability for superintendents.

Another variable, the total number of board member changes, was created by taking the total number of elections, as reported on those variables dealjing directly with board members, and subtracting those elections in which an incumbent board member was reelected from that total number (see Table 24). The variable was partitioned into three groups; zero through one, two through four, and five through eight for the purposes of performing a second statistical analysis. A chi-square test of independence was then performed (chi-square $=7.966, \underline{d f}=2$, and $\underline{p}=.019$ ) . The statistical hypothesis that board member changes and turnover in the office of the superintendent are independent was rejected. Of particular interest is that when board member turnover is excessive (five to eight turnovers), the turnover rate for superintendents is 100\%. The second highest turnover for superintendents occurs when the board turnover is lower than expected (zero through one) at $63 \%$. When board member turnover is modest (two to four) superintendent turnover is also modest ( $38 \%)$. 
Table 24

Changes in Board Membership and superintendent Turnover

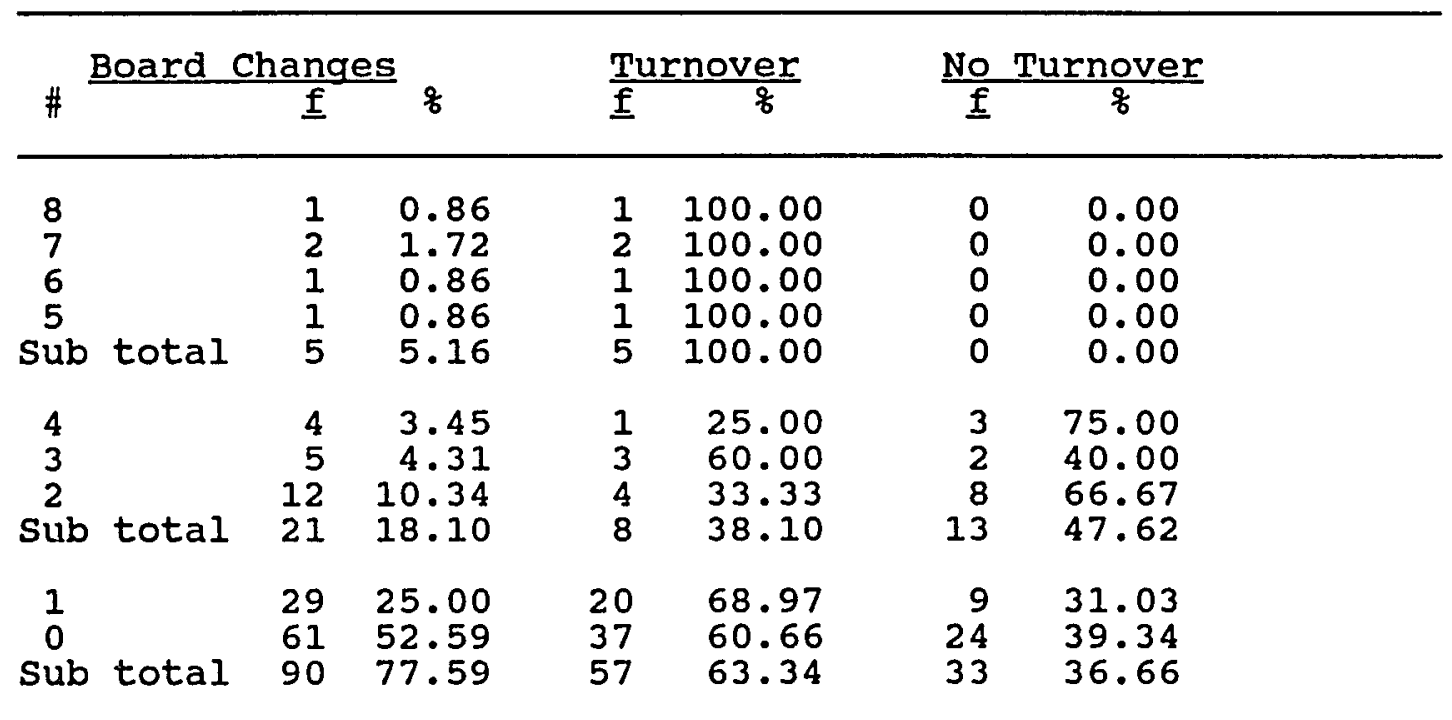

NOTE: Data were grouped into zero through one, two through four, and five through eight (chi-square $=7.966$, df $=2$, and $\mathrm{p}=.019$ ). The low expected values in two cells associated with board member turnover of five or more (a number equal to the board's size) produced a warning that $33 \%$ of the cells had expected values under five. The first column of percentages is computed on the total number of districts; all other percentages are row percentages.

Relationship with the Board

Approximately $60 \%$ of the superintendencies in the 116 school districts became vacant during the five-year period studied. Questions relating to the disposition of the superintendents who left their districts show that $27 \%$ found other jobs, $27 \%$ retired, and $46 \%$ left the district as a result of "an agreement with the board" (see Table 25). The fact that 32 , or nearly half, of the superintendents who left their districts did so after making an arrangement with their boards indicates that the relationship between these 
superintendents $\mid$ and their boards was poor and that these 32 superintendents apparently were not in good standing with their boards at the time they left the district.

Table 25

Disposition of superintendents Leaving the District

\begin{tabular}{|c|c|c|}
\hline Disposition & $\underline{\mathbf{f}}$ & $\%$ \\
\hline $\begin{array}{l}\text { Other Position } \\
\text { Retired } \\
\text { Arrangement }\end{array}$ & $\begin{array}{l}19 \\
19 \\
32\end{array}$ & $\begin{array}{l}27.14 \\
27.14 \\
45.71\end{array}$ \\
\hline
\end{tabular}

Current chief executives reported that the previous superintendents" relationships with their boards were excellent in $18 \%$ of the cases, good in 41\%, and poor to bad in $41 \%$ of the cases. Although this data, for the most part, must be considered "hearsay" information because it comes from people, a majority of whom were not a part of the school district at the time the previous superintendency became vacant, it does match other data gathered in this study (see Table 26). A chi-square test of independence was performed on the predecessors' relationship with the board and superintendent turnover. The statistical hypothesis that the superintendents' relationships with their boards and superintendent turnover are independent was not rejected (chi-square $=31.348, \underline{\mathrm{df}}=3$, and $\underline{\underline{p}}=.341)$. 
Table 26

Predecessor Relationship|with thelBoard of Directors and superintendent Turnover

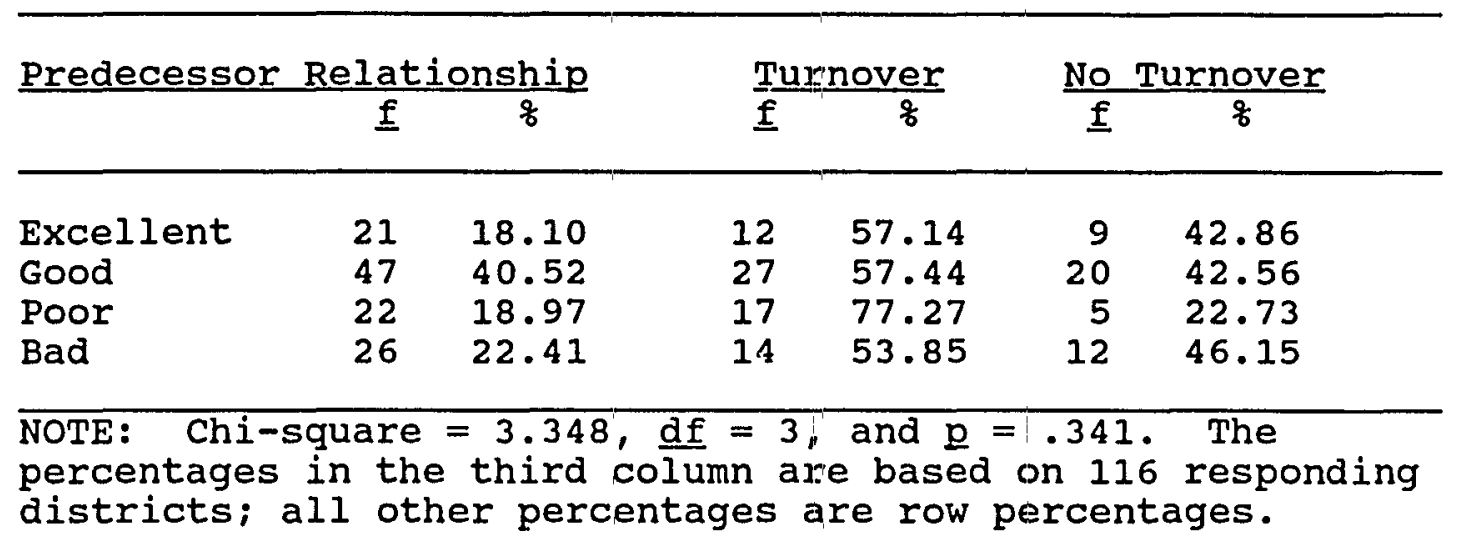

A second question on the questionnaire dealt with the amount of opposition the current superintendent felt his/her predecessor had from the board. Ilable 27 displays the data gathered from this question. Current superintendents reported that their predecessors had a good relationship with little or no opposition on the board in $27 \%$ of the cases, were opposed by a minority in 17\%, were opposed by a majority in $34 \%$, and were fired in $4 \%$ of the cases. A chi-square test of independence was performed on the predecessors' opposition by their board and superintendent turnover (chi-square $=5.385, \underline{\mathrm{df}}=3$, and $\mathrm{E}=.146$ ). The statistical hypothesis that the opposition/on the board of directors and superintendent turnover are independent was not rejected. There does not appear to belany relationship between the superintendent's relationship to the board or 
opposition by the board, as perceived by the superintendent following, and superintendent turnover.

When the relationship between the board and the superintendent was good, turnover in the superintendency was 51\% (see Table 21). When there was some opposition, the turnover range was $67 \%$ to $75 \%$. When the opposition was severe, the turnover rate was $64 \%$.

It should be noted, however that the respondents were not limited to a five-year period in discussing the superintendents' relationship to or opposition by the board whereas change in superintendents was limited to the fiveyear period under study. This may partially explain the inconsistency in the "fired" category in which there was no superintendent turnover in two cases and may partially account for the failure to find a relationship between superintendent turnover and opposition by the board. Although the questionnaire permitted multiple marks on this item, none of the respondents checked multiple response categories. With the "fired" category excluded from the board opposition variable, the chi-square test of independence was repeated. The statistical hypothesis that superintendent turnover and opposition on the board of directors are independent was rejected (chi-square $=4.202$, $\underline{\mathrm{df}}=1$, and $\underline{\mathrm{p}}=.040)$. There appears to be a relationship between board opposition to the superintendent and superintendent turnover. 
Table 27

opposition on the Board of Directors and superintendent Turnover

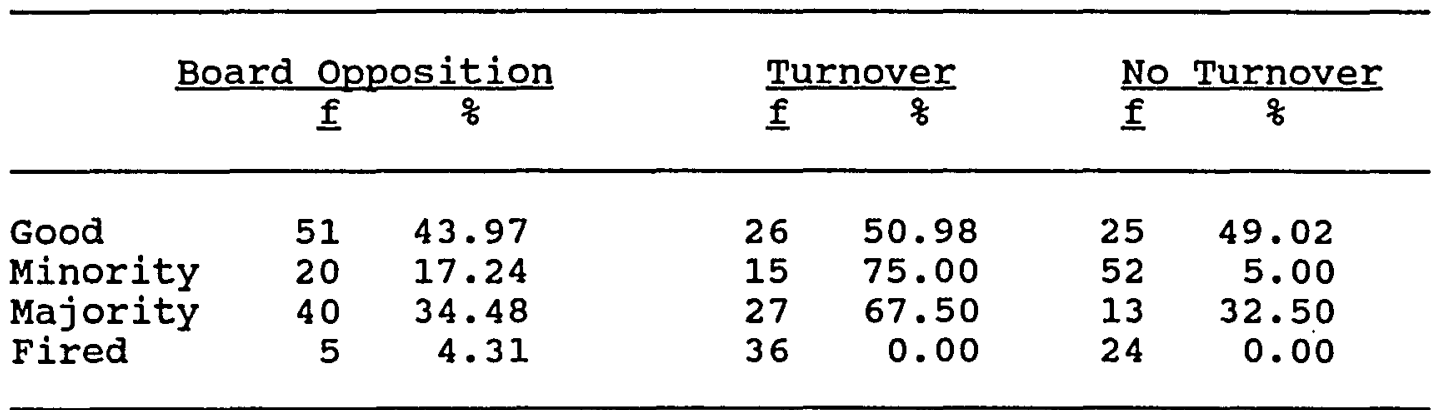

NOTE: To obtain adequate expected frequencies and match other statistical analyses later in this chapter, majority opposition and fired were combined. Chi-square $=5.385$, df $=3$, and $\mathrm{p}=.146$. With "fired" excluded from the analysis, chi-square $=4.202, \underline{\mathrm{d} f}=1$, and $\mathrm{p}=.040$. Percentages in the third column are based on 116 responding districts; all other percentages are row percentages.

\section{Political climate}

In $62 \%$ of the cases, current superintendents reported that the political climate in the district was "hot," active or very active, in their predecessors' district during the time that the superintendent vacancy occurred, while only $38 \%$ responded that the district was calm before his/her predecessor left. A chi-square test of independence was conducted on the relationship between political climate and superintendent turnover. The statistical hypothesis that political climate and superintendent turnover are independent was rejected (chi-square $=13.108, \underline{\text { df }}=2$, and $\mathrm{p}$ $<.002)$. Therefore superintendent turnover is more likely to occur when the political climate is hot (see Table 28). Some caution should be exercised at this point in 
interpreting this data. Superintendent turnover data were limited to a five-year period. The data concerning political climate were not specifically limited to that same period.

Table 28

Political climate and superintendent Turnover

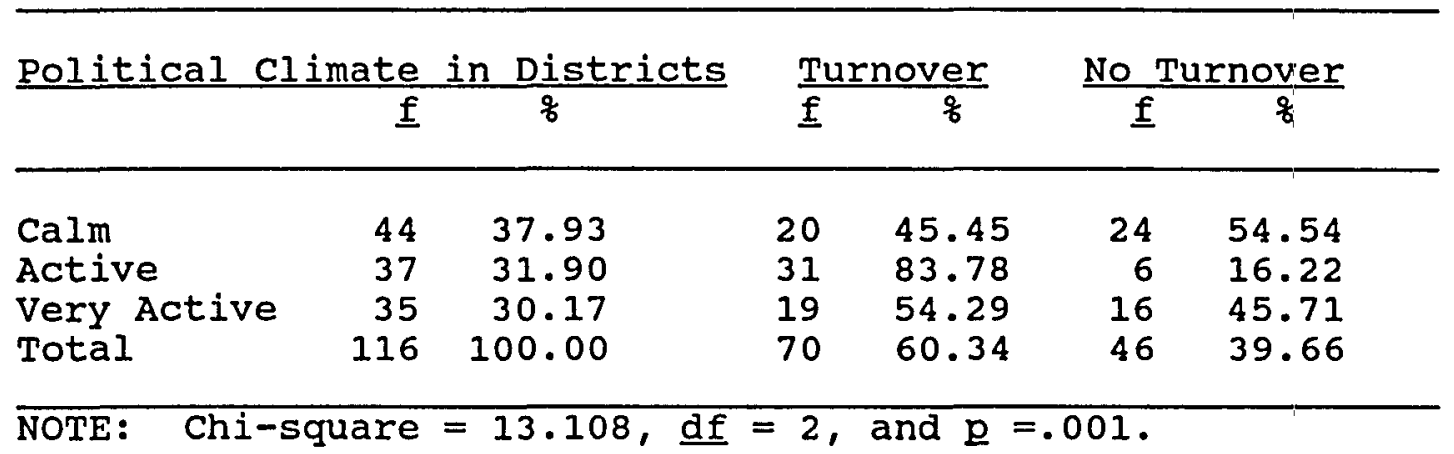

A chi-square test of independence was then conducted on the relationship between the political climate and board opposition to its chief executive officer (see Table 29). Since "active" and "very active" are subjective terms the data were grouped into two groups, calm and active. To obtain adequate expected frequencies in all cells, opposition by the board was partitioned into three groups; good relationship, opposed by a minority of the board, and opposed by a majority of the board/fired. Opposition by a majority of the board and fired may be inclusive of the same set of superintendents. A chi-square test of independence was performed on the grouped data. To be fired, a 
superintendent would necessarily be opposed by a majority of the board. Although the "fired" in this variable comes from a separate question from superintendent change, those included in the "fired" response must have been "yes" in the other variable. Therefore, the analysis was repeated, with the "fired" category excluded from the board opposition variable. The research hypothesis was rejected (chi-square $=21.417, \underline{\mathrm{df}}=2$, and $\underline{p}>001)$.

Table 29

Political Climate and Board Opposition to the superintendent

\begin{tabular}{|c|c|c|c|c|c|c|}
\hline \multirow{2}{*}{ Board Opposition } & \multicolumn{2}{|c|}{$\mathrm{Calm}$} & \multicolumn{2}{|c|}{ Active } & \multicolumn{2}{|c|}{ Total } \\
\hline & $\overline{\underline{f}}$ & $\frac{q}{q}$ & $\underline{\underline{f}}$ & $\overline{8}$ & $\underline{\underline{f}}$ & $q$ \\
\hline Good relationship & 31 & 60.78 & 20 & 39.22 & 51 & 43.97 \\
\hline Opposed minority & 6 & 30.00 & 14 & 70.00 & 20 & 17.24 \\
\hline opposed majority & 7 & 17.50 & 33 & 82.50 & 40 & 34.48 \\
\hline Fired & 0 & 0.00 & 5 & 100 & 5 & 4.31 \\
\hline
\end{tabular}

NOTE: Grouped data, good relationship, opposed by minority, opposed by majority/fired; chi-square $=21.417, \underline{\mathrm{df}}=2$, and p $>.001$. Grouped data, good relationship and opposed by a minority/majority of the board excluding "fired"; chi-square $=17.630, \underline{\mathrm{df}}=1$, and $\underline{\mathrm{p}}<.001$.

of the superintendents who were reported to have had a "good relationship" with their boards, $61 \%$ were in a calm political climate, whereas when the political climate was active, only $39 \%$ were reported to have had a good relationship with their boards. Conversely, of those superintendents who were reported to have had a minority of 
opposition on the board, $30 \%$ were in a calm political climate and $70 \%$ were in an active political climate. This trend in the relationship between the two variables continues: when the opposition on the board increases to a majority, | only $18 \%$ of the superintendents faced this kind of opposition in a politically calm climate while $83 \%$ faced majority opposition in an active political climate. For all five of the fired superintendents, the political climate was active. It appears that when the political climate in/the district is calm, it is less difficult for a superintendent to maintain good relationships with his/her board. As the political climate increases in activity, the likelihood that a superintendent will face opposition on his/her board also increases.

A second partitioning of this data was performed to determinelif political activity, an active climate, was associated with any opposition by the board to the superintendent. The research hypothesis that opposition by the board to the superintendent and political climate are independent was rejected (chi-square $=17.630, \underline{\mathrm{df}}=1$, and $\underline{p}$ $(.001)$. When the political climate was calm, the relationship between the superintendent and the board was good in $61 \%$ of the cases; under active climate conditions the relationship deteriorated to $39 \%$. When there was any level of opposition including "fired," the political climate was reported to be active in $80 \%$ of the 70 cases. 
Table 30 displays the data gathered from the second question on the questionnaire dealing with the superintendents relationships with their boards. The responses to the question were divided into four categories: excellent, good, poor, and bad relationships. Again, the relationship between the board and the superintendent appeared to be better when the political climate in the district is calm. Current superintendents reported that their predecessors had an excellent relationship with their boards during calm political climate in $67 \%$ of the cases, while only $33 \%$ had that relationship during times of political activity. A chi-square test of independence was performed with political climate and board relationship as the independent variables. As noted previously, political climate was partitioned into two groups, calm and active. The statistical hypothesis that political climate and superintendent/board relations are independent was rejected (chi-square $=24.551, \underline{\mathrm{df}}=3$, and $\mathrm{p}<.001)$

When the relationship of the superintendent with the board was excellent, the poljtical climate was calm in $67 \%$ of the cases and when the relationship was good the political climate was calm in $51 \%$ of the cases. However when the relationship was poor, the climate was active in $82 \%$ of the cases and when the relationship was bad the climate was active in 928 of the cases. 
Table 30

Political climate and Board Relationship to the superintendent

\begin{tabular}{|c|c|c|c|c|c|c|}
\hline \multirow[t]{2}{*}{ Board Relationship } & \multicolumn{2}{|c|}{ Calm } & \multicolumn{2}{|c|}{ Active } & \multicolumn{2}{|c|}{ Total } \\
\hline & $\underline{\underline{f}}$ & $\frac{q}{q}$ & $\underline{\mathbf{f}}$ & $\frac{8}{8}$ & $\underline{f}$ & $\frac{8}{8}$ \\
\hline $\begin{array}{l}\text { Excellent } \\
\text { Good } \\
\text { Poor } \\
\text { Bad }\end{array}$ & $\begin{array}{r}14 \\
24 \\
4 \\
2\end{array}$ & $\begin{array}{r}66.67 \\
51.06 \\
18.18 \\
7.69\end{array}$ & $\begin{array}{r}7 \\
23 \\
18 \\
24\end{array}$ & $\begin{array}{l}33.33 \\
48.94 \\
81.82 \\
92.31\end{array}$ & $\begin{array}{l}21 \\
47 \\
22 \\
26\end{array}$ & $\begin{array}{l}18.10 \\
40.52 \\
18.97 \\
22.41\end{array}$ \\
\hline
\end{tabular}

NOTE: Chi-square $=24.551, \underline{\mathrm{df}}=3$, and $\mathrm{p}<.001$.

Dependence was discovered between political climate and board turnover, between political climate and superintendent turnover, and between superintendent and board relationships. Having discovered that these relationships exist and by grouping variables into calm and active for political climate and good and all others for board opposition, a three-way chi-square test of independence was performed (Mantel-Haenszel chi-square $=4.364$, $\underline{\mathrm{df}}=5$, and $\underline{\mathrm{p}}$ $=.037)$. The statistical hypothesis that superintendent turnover, board relationship, and political climate in the district are independent was rejected (see Table 31). There were 73 superintendent turnovers during the period of study, with $53(73 \%)$ of these turnovers taking place in districts where the political climate was described by the current superintendent as active. Note that $48 \%$ of the superintendents who lost their positions did so when their 
relationship with the board was not good and the political climate was active and only $25 \%$ of those who were replaced, left when the climate was active but their relationship with the board was good. When the relationship with the board was poor 35 (83\%) of the 42 superintendent changes occurred under active political conditions; when the relationship was good, 18 (58\%) of the 31 changes occurred in and active political climate. Given this data, it appears that the catalyst in finding dependence in the three-way analysis is political climate.

Table 31

Superintendent Turnover, Board opposition, and Political climate

\begin{tabular}{|c|c|c|c|c|c|c|c|c|c|}
\hline \multirow[b]{3}{*}{ Supt Change } & \multicolumn{4}{|c|}{ Relationship Good } & \multicolumn{5}{|c|}{$\begin{array}{l}\text { Opposed by } \\
\text { Minority/Majority/Fired }\end{array}$} \\
\hline & \multicolumn{2}{|c|}{ calm } & \multicolumn{2}{|c|}{ Active } & \multicolumn{2}{|c|}{ Calm } & \multicolumn{2}{|c|}{ Active } & \multirow{2}{*}{$\frac{\text { Total }}{\underline{f}}$} \\
\hline & $\underline{\underline{\mathbf{f}}}$ & $\frac{9}{6}$ & $\underline{\underline{f}}$ & 8 & $\underline{f}$ & $q$ & $\underline{f}$ & $q$ & \\
\hline Yes & 13 & 17.81 & 18 & 24.66 & 7 & 9.59 & 35 & $\begin{array}{l}47.9 \\
5\end{array}$ & 73 \\
\hline No & 18 & 41.86 & 71 & 6.28 & 61 & 3.95 & 12 & $\begin{array}{l}27.9 \\
1\end{array}$ & 43 \\
\hline Total & 31 & 26.72 & 25 & 21.55 & 13 & 11.21 & 47 & $\begin{array}{l}40.5 \\
2\end{array}$ & 116 \\
\hline
\end{tabular}

NOTE: Grouped data: good relationship and the combination of opposed by minority opposed majority, and fired;

chi-square $=4.364, \underline{\mathrm{df}}=5$, and $\mathrm{p}=.037 . \quad$ Excluding "fired" from the analysis yielded a chi-square of $4.202, \underline{\mathrm{df}}=5$, and $\underline{p}=.040$. All percentages are row percentages. 
Bond Attempts

An indicator of the political climate in a district may be seen in the district's attempt to gain voter approval of a bond issue. There were nine ( $8 \%$ ) successful bond attempts during the period of study. Out of the nine attempts only three were successful when attempted during a period of political activity in the district. Table 32 shows the two to one ratio established in successful bond attempts when the political climate is calm. The data indicated that more than half (65\%) of the unsuccessful bond measure attempts took place in districts which were described as politically active at the time of the election. The sample was too small to permit an accurate statistical analysis of these figures, however it appears that a school district may be twice as likely to pass a bond measure when the political climate is calm and conversely, may be twice as likely to fail a measure when the climate in the district is politically active.

Table 32

Bond Attempts and Political climate of Districts

Bond Attempt

\begin{tabular}{lrlll}
\hline Successful & 6 & 66.67 & 3 & 33.33 \\
Unsuccessful & 38 & 35.51 & 69 & 64.49 \\
Total & 44 & 37.93 & 72 & 62.0 \\
\hline
\end{tabular}




\section{Discriminant Analysis of Variables and Superintendent Turnover}

The questionnaire yielded 17 variables which were considered independent from each other. After initial testing, eight variables were selected as the best combination for the discriminant univariate and discriminant analyses. The eight variables were: (a) Relationship, (b) Position, (c) Percentage, (d) Climate, (e) Contested, (f) students, (g) Unsuccessful elections, and (h) Service. These variables were studied to determine their association with superintendent turnover.

Relationship: The respondent was asked to indicate his/her predecessor's relationship to the board of directors at the time the superintendent left the district (see Appendix A, question 8). There were four possible responses: opposed by a minority of the board, opposed by a majority of the board, dismissed through board action, and in good standing with the board. None of the responding superintendents chose multiple response categories to this question.

Position: The questionnaire (Appendix A, question 10) asked the current chief executive officer to indicate the number of board positions open during the five-year period of this study that might result in board member loss of position. Initial tabulation of this variable indicated that it is curvilinear in nature with fewer than five 
elections and greater than eight elections being associated with increased superintendent turnover. The expected number of elections for a five-member board, given staggered fouryear terms of office in a five-year period, should range between five and eight elections (see Table 13). To adjust for the curvilinear nature of this relationship, a new variable was created. The expected range, five to eight elections, was given the value of one. Elections greater or lesser than one were given corresponding absolute values, five to seven elections equaled one, four elections and eight elections equaled two, and so on.

Percentage: A separate question on the questionnaire (see Appendix A, question 1) yielded the total number of elections during the period of the study. Percentage is the result of dividing the number of responses to the contested elections question (question 11) by the total number of elections (position variable).

Climate: Respondents were asked to describe the political climate in the district at the time the previous superintendent left office. Their choices were calm/, active, and very active. Active and very active were combined to provide adequate numbers in all cells for the purpose of statistical analysis.

Contest: The questionnaire (see Appendix A, question 11) asked respondents to indicate the total number of contested elections during the last five years. Initial 
tabulation of this variable indicated, as in the case of position, that a curvilinear relationship exists, with very few and many contested elections being associated with increased superintendent turnover (see Table 22). Unlike the position variable, there was no way to determine an "expected" number of contested elections. It was decided to use the median number of contested elections because the median is uninfluenced by the skewed distribution of the raw data. The number of contested elections was tabulated to determine the median value and the median was determined to be two; this was assigned the absolute value of zero. Numbers of contested elections greater or lesser than the median were assigned absolute numbers increasing from the median. Three and one contested elections equaled the absolute value of two, four and zero equaled three and so on.

Students: | The number of students in each of the responding districts was obtained from the oregon school Directory (Oregon Department of Education, 1994). The district identification number was used to link the district with the data from the directory.

Elections: The questionnaire asked respondents to list all of the board members who faced election during the fiveyear period of Istudy and whether those elections were successful (see Appendix A, question 12). The number of successful elections was then subtracted from the total 
number of elections yielding the elections variable, which is the number of unsuccessful elections.

Superintendent Change: The first question of the questionnaire yielded the number of months that the current superintendent had been in office. Districts in which the current superintendent reported having been in office for 59 or fewer months were recorded as having had a superintendent turnover within the five-year period of study. The data were used in creating the superintendent change variable.

\section{Univariate Analysis}

The univariate analysis output was used to examine the relationship of each independent variable with superintendent change (see Table 33).

Table 33

Analysis of Corollaries of Superintendent Turnover

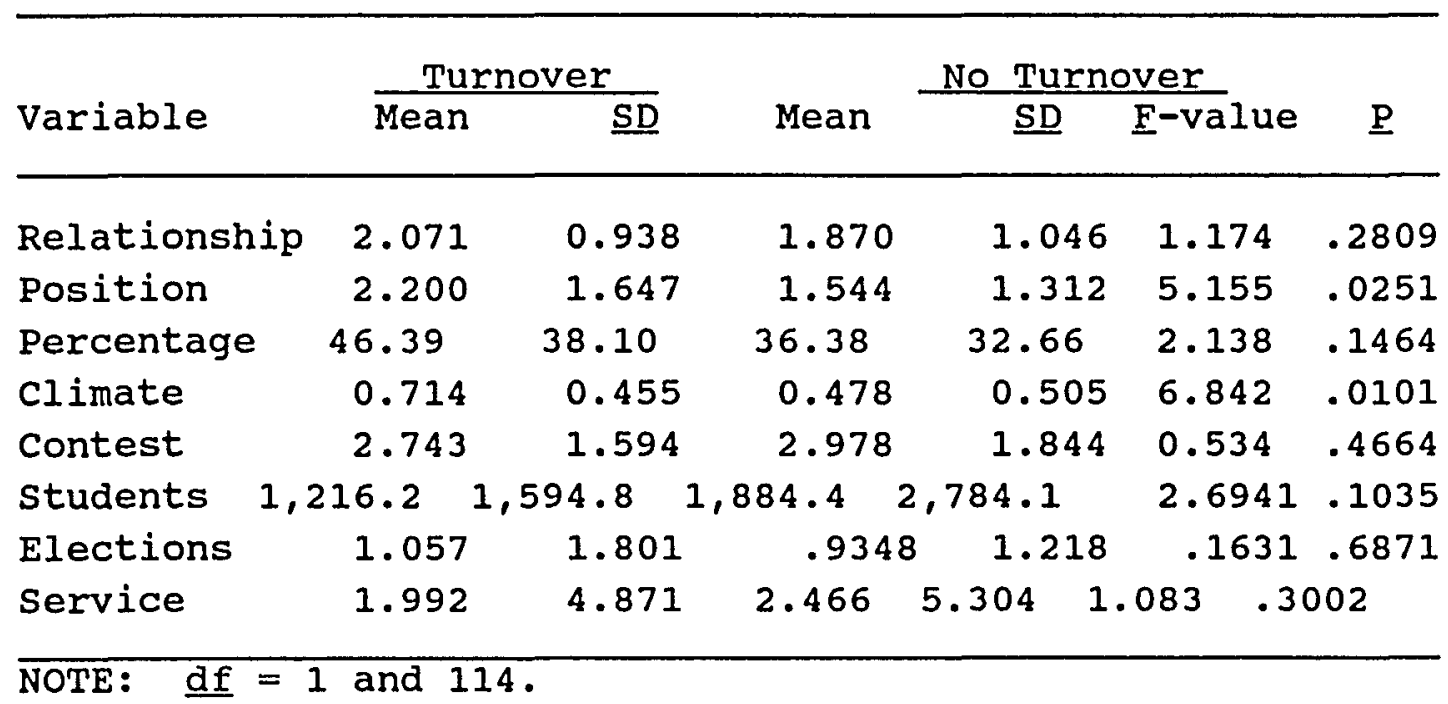


The statistical hypotheses for climate $(\underline{F}=6.84, \underline{p}=$ .01) and position ( $\underline{F}=5.15, \underline{p}=.03)$ were rejected. Both variables significantly differentiated between districts without and districts with superintendent change. Relationship $(\underline{F}=1.17, \underline{p}=.28)$, percentage $(\underline{F}=2.14, \underline{p}=$ $.15)$, contested $(\underline{F}=.53, \underline{p}=.47)$, students $(\underline{F}=2.69, \underline{p}=$ $.1035)$, elections $(\underline{F}=.1631, \underline{p}=.687)$ and service $(\underline{F}=$ 1.0831, $\underline{p}=.3002$ ) did not significantly differentiate between these two groups.

\section{Discriminant Analysis}

Discriminant analysis was used to evaluate whether the eight variables could, in combination, construct a linear discriminant function that would differentiate between superintendents who were in jeopardy of losing their positions (turnover) and those who were not in jeopardy (no turnover).

The researcher employed the "direct method of analysis," which employs all of the variables. This method was chosen over the "stepwise method," which uses only those variables that in isolation prove to differentiate between the two groups at a statistically significant level. The "direct method" was deemed appropriate for this analysis because it allowed for the evaluation of the interaction of all of the relevant variables.

The resulting group means, standard deviations and corresponding F-values were presented in Table 34. The 
discriminant function resulting from this use of these eight variables (chi-square $=18.876, \underline{d f}=8$, and $\underline{p}=.0155)$ was significant. The standardized discriminate function coefficients for these variables are presented in Table 34 .

Table 34

Standardized Discriminant Function Coefficients for selected Variables and Superintendent Turnover

\begin{tabular}{cc}
\hline Variable & Standardized Value \\
Relationship & -0.105 \\
Position & 0.739 \\
Percentage & 0.554 \\
Climate & 0.548 \\
Contest & -0.701 \\
Students & -.2298 \\
Elections & -.2179 \\
Service & -.2084 \\
Chi-square $=18.88$, df $=8$, and $\mathrm{p}=.0155$. \\
NOTE: \\
When discriminant function was used to predict \\
superintendent turnover for this group of superintendents it \\
correctly classified $84 \%$ of the superintendents who left \\
their positions and correctly classified $52 \%$ of those who \\
did not leave their positions. overall, $72 \%$ were correctly \\
classified (see Table 35 ).
\end{tabular}


Table 35

Classification Results of Discriminant Analysis of Selected Variables and Superintendent Turnover

\begin{tabular}{|c|c|c|c|c|}
\hline \multirow[b]{2}{*}{ Actual } & \multicolumn{4}{|c|}{ Prediction } \\
\hline & $\underline{\mathrm{N}}$ & $\frac{\overline{T u}}{\underline{\underline{\underline{f}}}}$ & $\frac{1 \text { over }}{\frac{q}{8}}$ & $\begin{array}{lc}\text { No } & \text { Turnover } \\
\underline{\underline{f}} & \frac{q}{6}\end{array}$ \\
\hline $\begin{array}{l}\text { Turnover } \\
\text { No Turnover }\end{array}$ & $\begin{array}{l}70 \\
46\end{array}$ & $\begin{array}{l}59 \\
22\end{array}$ & $\begin{array}{l}84.3 \\
47.82\end{array}$ & $\begin{array}{r}15.7 \\
2.2\end{array}$ \\
\hline
\end{tabular}

NOTE: Percentage of grouped cases correctly classified: $71.55 \%$

In examining the univariate analyses of the eight variables, six variables were found not significant. Various combinations of these variables with the two significant ones were used in subsequent discriminate analyses to discover that combination of variables that would come closest to exhibiting the prediction effectiveness of the all eight combination. This was done to yield the most effective combination of variables. The students, elections, and service variables were eliminated because of their minimal contribution. The univariate analyses were presented in Table 33.

The resulting group means, standard deviations and corresponding F-values were presented in Table 33. The discriminant function resulting from this use of the six variables (chi-square $=16.894, \underline{\mathrm{df}}=5$, and $\underline{\underline{ }}=.0047$ ) was significant. The standardized discriminate function coefficients for these variables are presented in Table 36 . 
Table 36

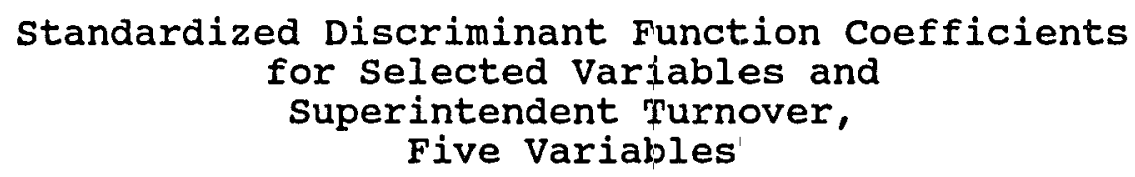

\begin{tabular}{lc}
\hline Variable & Standardized Value \\
\hline Relationship & -0.105 \\
Position & 0.739 \\
Percentage & 0.554 \\
Climate & 0.548 \\
Contest & -0.701 \\
\hline NOTE: Chi-square $=16.894, \underline{\text { df }}=5$, and $\mathfrak{p}=.0047$.
\end{tabular}

When discriminant function was used to predict superintendent turnover for this group of five variables with superintendent turnover, it correctly classified $86 \%$ of the superintendents who left their positions and classified $48 \%$ of those who did not leave their positions. Overall $71 \%$ were correctly classified (see Table 37 ). Note that there was a $1 \%$ slippage in the overall correct classification when the number of variables was reduced (see Table 37).

Further attempts at reducing the variables used in this analysis yielded less significant results. An attempt was made to use only those variables that had significant $\underline{F-v a l u e s ; ~ p o s i t i o n ~}(\underline{F}=5.1545, \underline{p}=.0251)$, and climate $(\underline{F}=$ $6.8424, \mathrm{p}=.0101)$. The resulting discriminant function was somewhat less effective in classifying superintendent 
turnover, however the analysis did yield a significant chj-square (see Table 38 ).

Table 37

Classification Results of Discriminant Analysis of Selected Variables and Superintendent Turnover, Five Variables

Actual Group

$\underline{\mathrm{N}}$

Prediction

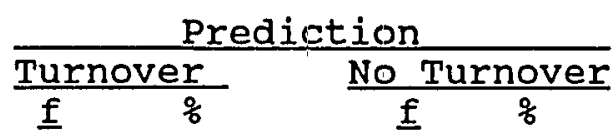

\begin{tabular}{llllll}
\hline Turnover & 70 & 60 & 85.7 & 10 & 14.3 \\
No Turnover & 46 & 24 & 52.2 & 22 & 47.8 \\
\hline
\end{tabular}

NOIEE: Percentage of grouped cases correctly classified: 70.698

Table 38

Classification Results of Discriminant Analysis of Selected Variables and superintendent Turnover, Five Variables

\begin{tabular}{|c|c|c|c|c|c|}
\hline \multirow{3}{*}{ Actual Group } & \multirow[b]{3}{*}{$\underline{\mathbf{N}}$} & \multicolumn{3}{|c|}{ Prediction } & \\
\hline & & \multicolumn{2}{|c|}{ Turnover } & \multicolumn{2}{|c|}{ No Turnover } \\
\hline & & $\underline{\underline{f}}$ & $\frac{q}{8}$ & $\underline{\underline{f}}$ & $\frac{8}{8}$ \\
\hline Turnover & 70 & 56 & 80.0 & 14 & 20.0 \\
\hline No Turnover & 46 & 24 & 52.8 & 22 & 47.2 \\
\hline
\end{tabular}


The Relationship of District size and the Number of Schools in the District to superintendent and Board Turnover

Research question number five in this study concerned those factors that relate to both turnover in the office of the chief executive officer and in board membership as might be related to the size of the school district. The study examined two areas of district size. The areas studied were the number of teachers and the number of buildings or schools. It should be noted that no differentiation is made between the number of buildings and the number of schools for the purposes of this analysis.

Size and Superintendent Turnover

The smallest district in the study employed six teachers, for approximately 10 students, in one building. The largest district studied employs 555 teachers, for 10,914 students in 14 buildings. The average district in the study had 78.98 teachers for $1,481.17$ students housed in 3.14 buildings (see Tables 1 and 2). District size as measured by the number of schools and the number of teachers was studied in relationship to both superintendent and board member turnover.

Teachers were grouped in sets of $100(0-99,100-199$, and so on). To perform a chi-square test of independence on this data, districts with 200 or more teachers were combined into one category. Since there is a direct relationship 
between the number of students and the number of schools, no analysis of the number of students and superintendent/board member turnover was performed (see Table 39).

Table 39

Number of Schools and Superintendent Turnover

\begin{tabular}{|c|c|c|c|c|c|c|}
\hline \multirow[b]{2}{*}{ Schools } & \multicolumn{2}{|c|}{ Turnover } & \multicolumn{2}{|c|}{ No Turnover } & \multicolumn{2}{|c|}{ Total } \\
\hline & $\underline{\underline{f}}$ & $\frac{9}{6}$ & $\underline{f}$ & $\frac{q}{b}$ & $\underline{\underline{f}}$ & 8 \\
\hline 14 & 0 & 0.00 & 2 & 100 & 2 & 1.90 \\
\hline 13 & 0 & 0.00 & 0 & 0.00 & 0 & 0.00 \\
\hline 12 & 0 & 0.00 & 1 & 100 & 1 & 0.86 \\
\hline 11 & 3 & 42.86 & 4 & 57.14 & 7 & 6.03 \\
\hline 10 & 0 & 0.00 & 0 & 0.00 & 0 & 0.00 \\
\hline 9 & 3 & 75.00 & 1 & 24.00 & 4 & 3.45 \\
\hline 8 & 0 & 0.00 & 0 & 0.00 & 0 & 0.00 \\
\hline 7 & 1 & 25.00 & 3 & 75.00 & 4 & 3.45 \\
\hline 6 & 3 & 75.00 & 1 & 25.00 & 4 & 3.45 \\
\hline 5 & 5 & 83.33 & 1 & 16.67 & 6 & 5.17 \\
\hline 4 & 3 & 75.00 & 1 & 25.00 & 4 & 3.45 \\
\hline 3 & 8 & 80.00 & 2 & 20.00 & 10 & 8.62 \\
\hline 2 & 9 & 56.25 & 7 & 43.75 & 16 & 13.79 \\
\hline 1 & 35 & 60.34 & 23 & 39.66 & 58 & 50.00 \\
\hline
\end{tabular}

NOTE: Chi-square $=3.816, \mathrm{df}=4$, and $\mathrm{p}=.431$. The first column of percentages is calculated on the total number of schools; all percentages are row percentages.

Table 39 displays the data concerning the number of schools and superintendent turnover. Because of low expected frequency, the data were placed into five groups for analysis: 1 school, 2 schools, 3 schools, 4-7 schools, and 8-14 schools. A chi-square test of independence was performed on the resulting data. The statistical hypothesis 
that the number of schools and superintendent turnover are independent was not rejected (chi-square $=3.816, \underline{\text { df }}=4$, and $\mathrm{p}=.431$ ). No relationship between school size and superintendent turnover was found.

Table 40 displays the data concerning the number of teachers and superintendent turnover. For the purposes of analyzing this data it was partitioned into three groups: 0-99, 100-199, and 200 and above. A chi-square test of independence was performed on this data (chi-square $=2.051$, $\underline{d f}=2$, and $\underline{p}=.359)$. The statistical hypothesis that the number of teachers and turnover in the office of superintendent are independent was not rejected. | No relationship between the number of teachers in a district and superintendent turnover was found.

\section{Table 40}

Number of Teachers and Superintendent Turnover

\begin{tabular}{|c|c|c|c|c|c|c|}
\hline \multirow[b]{2}{*}{ Teachers } & \multicolumn{2}{|c|}{ Turnover } & \multicolumn{2}{|c|}{ No Turnover } & \multicolumn{2}{|c|}{ Total } \\
\hline & $\overline{\mathbf{f}}$ & $q$ & $\underline{f}$ & 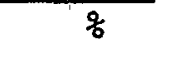 & $\overline{\mathbf{f}}$ & $\frac{8}{8}$ \\
\hline $500+$ & 0 & 0.00 & 2 & 100 & 12 & 1.72 \\
\hline $400-499$ & 0 & 0.00 & 0 & 0.00 & 10 & 0.00 \\
\hline $300-399$ & 2 & 33.33 & 4 & 65.67 & 6 & 5.17 \\
\hline $200-299$ & 4 & 66.67 & 2 & 33.33 & 6 & 5.17 \\
\hline $100-199$ & 9 & 64.29 & 5 & 35.71 & 14 & 12.07 \\
\hline $0-99$ & 55 & 62.50 & 33 & 37.50 & 88 & 75.62 \\
\hline
\end{tabular}


District Size and Board

Member Turnover

Turnover on the board of directors was analyzed in the same way as was district size and superintendent turnover. A chi-square test of independence was performed on district size as denoted by the number of schools and board member turnover. Because of low expected frequency in one cell the data were partitioned into two groups: one through three schools and four through 14 schools and a second analysis conducted (chi-square $=4.181, \underline{\mathrm{df}}=1$, and $\mathrm{p}=0.041$ ). The statistical hypothesis that the number of schools and board member turnover are independent was rejected. There is a relationship between the number of schools in a district and board member turnover (see Table 41).

Data concerning board member turnover and the number of teachers in the district was then analyzed using the following grouping; zero through 99 teachers, 100 through 199, and 200 through 500 teachers. A chi-square test of independence was performed on this data. The statistical hypothesis that district size as denoted by the number of teachers in a district and board member turnover are independent was not rejected (chi-square $=1.304, \underline{\mathrm{df}}=2$, and $\underline{p}=.521)$. No relationship between district size as denoted by the number of teachers and board member turnover was found (see Table 42). 
Table 41

Number of Schools and Board

Member Turnover

\begin{tabular}{crrrrrr}
\hline Schools & $\underline{\underline{f}}$ & \& & $\underline{\mathbf{f}}$ & $q$ & $\underline{f}$ & $q$ \\
\hline 14 & 2 & 100 & 0 & 0.00 & 2 & 1.90 \\
13 & 0 & 0.00 & 0 & 0.00 & 0 & 0.00 \\
12 & 1 & 100 & 0 & 0.00 & 1 & 0.86 \\
11 & 4 & 57.14 & 3 & 42.86 & 7 & 6.03 \\
10 & 0 & 0.00 & 0 & 0.00 & 0 & 0.00 \\
9 & 1 & 25.00 & 3 & 75.00 & 4 & 3.45 \\
8 & 0 & 0.00 & 0 & 0.00 & 0 & 0.00 \\
7 & 2 & 50.00 & 2 & 50.00 & 4 & 3.45 \\
6 & 1 & 25.00 & 3 & 75.00 & 4 & 3.45 \\
5 & 1 & 16.67 & 5 & 83.33 & 6 & 5.17 \\
4 & 2 & 50.00 & 2 & 50.00 & 4 & 3.45 \\
3 & 4 & 40.00 & 6 & 60.00 & 10 & 8.62 \\
2 & 4 & 43.75 & 9 & 56.25 & 16 & 13.79 \\
1 & 30 & 51.72 & 28 & 48.28 & 58 & 50.00
\end{tabular}

NOTE: Chi-square $=4.181, \underline{\mathrm{df}}=1$, and $\mathrm{p}=.041$.

(Chi-square is based on 1-3 schools against 4-14 schools.) The first column of percentages is tabulated on the total number of districts responding; all percentages are row percentages.

Table 42

Number of Teachers and Board Member Turnover

\begin{tabular}{|c|c|c|c|c|c|c|}
\hline \multirow[b]{2}{*}{ Teachers } & \multicolumn{2}{|c|}{ Turnover } & \multicolumn{2}{|c|}{ No Turnover } & \multicolumn{2}{|c|}{ Total } \\
\hline & $\underline{\mathbf{f}}$ & $\frac{q}{6}$ & $\underline{f}$ & $q$ & $\underline{\mathbf{f}}$ & $q$ \\
\hline $\begin{array}{l}500+ \\
400-499 \\
300-399 \\
200-299 \\
100-199 \\
0-99\end{array}$ & $\begin{array}{r}2 \\
0 \\
3 \\
3 \\
5 \\
42\end{array}$ & $\begin{array}{r}100 \\
0.00 \\
50.00 \\
50.00 \\
37.71 \\
47.73\end{array}$ & $\begin{array}{r}0 \\
0 \\
3 \\
3 \\
9 \\
46\end{array}$ & $\begin{array}{r}0.00 \\
0.00 \\
50.00 \\
50.00 \\
62.29 \\
52.27\end{array}$ & $\begin{array}{r}2 \\
0 \\
6 \\
6 \\
14 \\
88\end{array}$ & $\begin{array}{r}1.72 \\
0.00 \\
5.17 \\
5.17 \\
12.07 \\
75.62\end{array}$ \\
\hline \multicolumn{7}{|c|}{$\begin{array}{l}\text { NOTE: Chi-square }=1.304 \text {, } \frac{\mathrm{df}}{=}=2 \text {, and } \mathrm{p}=.521 \text {. Chi-square } \\
\text { tabulation matching that performed for the number of schools } \\
\text { and board member turnover was not possible due to lower than } \\
\text { expected frequencies in some cells. The first column of } \\
\text { percentages is tabulated on the total number of teachers; } \\
\text { all other percentages are row percentages. }\end{array}$} \\
\hline
\end{tabular}


Relationship of Geographic Location and Superintendent/Board Member Turnover

The sixth question posed by this study concerned the relationship, or lack of relationship, which might exist between turnover in the office of superintendent and on the school board and geographic location within the state. For the purposes of statistical analysis, the state was divided into three geographic areas: Pacific coast, willamette valley, and eastern Oregon (see Figure 1).

Geographic Location and Superintendent Turnover

Superintendent turnover was analyzed across the three geographical areas. No grouping of the data was necessary to perform a chi-square test of independence. The statistical hypothesis that the number of superintendent turnovers and geographic location are independent was not rejected (chi-square $=.849, \underline{\mathrm{df}}=2$, and $\mathrm{p}=.654)$. No relationship between geographic location and superintendent turnover was found (see Table 43).

Geographic Location and Board Member Turnover

Board member turnover was analyzed across the three geographical areas as it was with the superintendent turn over data. A chi-square test of independence was performed on this data. The statistical hypothesis that the number of board member turnovers and geographic location are 
independent was not rejected (chi-square $=.463, \underline{\mathrm{df}}=2$, and $\underline{p}=.793)$ (see Table 44$)$. No relationship between geographic location and board member turnover was found.

Table 43

Geographic Location and Superintendent Turnover

\begin{tabular}{|c|c|c|c|c|c|c|}
\hline \multirow[b]{2}{*}{ Location } & \multicolumn{2}{|c|}{ Turnover } & \multicolumn{2}{|c|}{ No Turnover } & \multicolumn{2}{|c|}{ Total } \\
\hline & $\underline{f}$ & $q$ & $\underline{\underline{f}}$ & $q$ & $\underline{\underline{f}}$ & $\frac{8}{8}$ \\
\hline Coast & 10 & 71.43 & 4 & 28.57 & 14 & 12.07 \\
\hline Valley & 41 & 59.42 & 28 & 40.58 & 69 & 59.48 \\
\hline Eastern & 19 & 57.58 & 14 & 42.42 & 33 & 28.45 \\
\hline
\end{tabular}

Table 44

Geographic Location and Board Member Turnover

Location

$\frac{\text { Turnover }}{\underline{f}} \frac{\text { No Turnover }}{\underline{q}} \frac{\text { Total }}{q} \quad \frac{\underline{f}}{q}$

\begin{tabular}{lrrrrrr}
\hline Coast & 7 & 50.00 & 7 & 50.00 & 14 & 12.07 \\
Valley & 34 & 49.28 & 35 & 50.75 & 69 & 59.48 \\
Eastern & 14 & 42.42 & 19 & 57.58 & 33 & 28.45
\end{tabular}

NOTE: Chi-square $=.463, \mathrm{df}=2$, and $\mathrm{p}=.793$. The first column of percentages is tabulated on the total number of districts responding; all other percentages are row percentages. 
School District Type

The seventh research question proposed by this study concerned those factors associated the relationship between the type of district (elementary, high school, or union high school) and superintendent, board member turnover. There were 116 school districts studied of which 38 (33\%) were elementary districts, 39 (34\%) were high school districts, and $39(34 \%)$ were union high school districts. The districts represent all of the geographic areas within the state.

Type of District and Superintendent Turnover

Table 45 displays the data gathered from the questionnaire regarding the type of school district and superintendent turnover. A chi-square test of independence was performed on this data. The statistical hypothesis that the type of school district and superintendent turnover are independent was not rejected (chi-square $=1.092, \underline{\text { df }}=2$, and $\mathrm{p}=.579)$. There appears to be no connection between the type of district and superintendent turnover. Turnover was equally divided among the three types of districts. 
Table 45

Type of School District and Superintendent Turnover

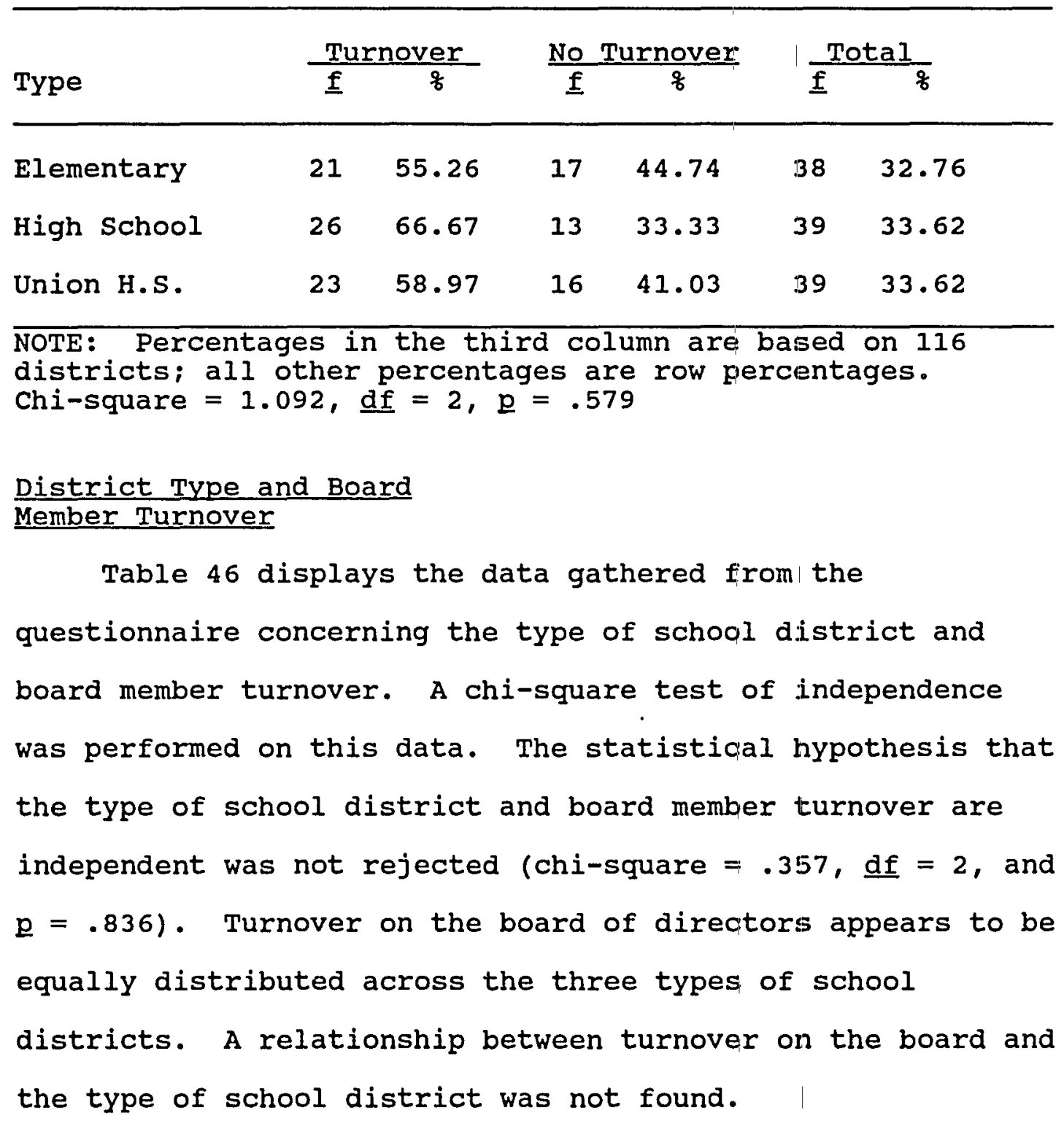


Table 46

School District Type and Board Member Turnover

\begin{tabular}{|c|c|c|c|c|c|c|}
\hline \multirow[b]{2}{*}{ Type } & \multicolumn{2}{|c|}{ Turnover } & \multicolumn{2}{|c|}{ No Turnover } & \multicolumn{2}{|c|}{ Total } \\
\hline & $\underline{\underline{f}}$ & $q$ & $\underline{f}$ & $\frac{f}{8}$ & $\underline{f}$ & $q$ \\
\hline Elementary & 19 & 50.00 & 19 & 50.00 & 38 & 32.76 \\
\hline High School & 19 & 48.72 & 20 & 51.28 & 39 & 33.62 \\
\hline Union H.S. & 17 & 43.59 & 22 & 56.41 & 39 & 33.62 \\
\hline
\end{tabular}


CHAPTER V

SUMMARY, CONCLUSIONS, AND

RECOMMENDATIONS

This chapter presents a summary of the research

findings, conclusions, and recommendations for further research.

\section{Summary}

The purpose of the study was to examine the factors related to the longevity of the chief executive officer and members of his/her school board. This summary examines the purpose, procedures and results of this study.

\section{Purpose}

This was a descriptive study. A mailed questionnaire was sent to all superintendents of districts governed by five-member school boards. The purpose of the study was to examine the factors related to the longevity of the chief executive officer and members of his/her school board. The study examined the issues surrounding the replacement of the superintendent and incumbent board members during a fiveyear period. The research questions examined for the study were:

1. What are the turnover rates within five years for: 
a. superintendents?

b. incumbent board members?

c. superintendents when an incumbent board member

fails to be reelected?

2. What are the factors associated with board member turnover?

3. What are the factors associated with superintendent turnover?

4. Are there variables which may be used together to discriminate between categories of the superintendent turnover?

5. What is the relationship of district size and number of schools in the district to superintendent turnover?

6. What is the relationship of geographic location of the districts to superintendent and board member turnover?

7. What is the relationship of the type of district (elementary, high school, or union high school) to superintendent and board member turnover?

\section{Procedure}

A questionnaire was developed and field tested by the researcher. The revised questionnaire was distributed to all districts in the state of oregon governed by a fivemember school board. The questionnaire was mailed to 179 school districts across the state; 147 districts met all of the criteria for inclusion in the study. Follow up 
interviews were conducted by the researcher, either by telephone or by facsimile, to ensure that the maximum number of accurate responses to the questionnaire was received. Due to failure to meet the criteria for inclusion in the study, 31 districts were eliminated from the study, leaving 116 qualified and responding districts. A response rate of $79 \%$ was obtained.

The data subsequently collected from the questionnaire was analyzed, using frequency distributions, percentages, row percentages, and cross tabulations. Chi-square was used as the test of statistical significance for statistical comparisons. To discover which variables might be used together to discriminate between categories of the superintendent variable, discriminate analysis was used.

\section{Results}

The results of the study are organized in a sequence matching the research questions asked by the study. Each question and its results are discussed in the numerical order presented earlier.

Turnover rate. During the five-year study, there were 70 districts out of 116 which reported that they had at least one vacancy in the office of the superintendent; the turnover rate for superintendents was $60 \%$. Districts reported that there were 631 board member openings during the study. Of the total number of openings, 446 resulted in contested elections, with 285 defeated incumbent board 
members. The turnover rate for incumbent board members in contested elections was $64 \%$. At a minimum, there were 47 vacancies in the office of the superintendent during the five-year period in which at least one incumbent board member was defeated. The turnover rate for superintendents associated with an incumbent defeat was $67 \%$. When board member turnover was excessive (five to eight turnovers in five years), the turnover rate for superintendents was 1008 . The data reported by responding districts was partitioned into two groups for the purposes of statistical analysis. The groups were, zero to four and five to 12 contested elections. A chi-square test of independence was then performed. The statistical hypothesis that the number of contested elections and superintendent turnover are independent was rejected $(\mathrm{p}<.01)$.

Factors associated with board member turnover. As reported by current superintendents, the mean number years of service by board members was 5.2 years, or slightly more than a single term of office. Defeat in an election accounted for $74 \%$ of board member turnover; however, $26 \%$ chose not to stand for reelection (automatically relinquishing their position). Further, $60 \%$ of the total board elections occurred when the political climate in the district was active. The statistical hypothesis that board member turnover and political climate are independent was not rejected $(p>.05)$. A chi-square test of independence was 
performed on the political climate, relationship the board had with the superintendent, and board member turnover variables. Turnover on the board, the relationship between the board and the superintendent, and political climate are not independent of each other $(\underline{p}<.01)$. Although political climate does not greatly impact the outcome of an incumbent's reelection attempts, when the board is experiencing some opposition to the superintendent and the climate is politically active, incumbents experience greater difficulty at the polls.

Factors associated with superintendent turnover. The 116 surveyed districts reported that there were 70 superintendent turnovers during the past five years. The majority of those turnovers (47) was associated with changes in board membership. The total number of openings on the board was analyzed with superintendent turnover, using a chi-square test of independence. The statistical hypothesis that the total number of openings on the board and superintendent turnover are independent was rejected ( $\mathrm{Q}<$ .01). It is interesting to note that the ratio of superintendent turnover is higher when there were nine or more openings on the board or less than five openings on the board in a five-year period; the lowest turnover rate for superintendents occurred in the expected (five to eight openings) range. The analysis was further refined to examine superintendent turnover related only to incumbent 
elections and a second analysis performed. The statistical hypothesis that the number of contested elections and superintendent turnover are independent of each other was rejected $(\mathrm{p}<.01)$. The greatest turnover $(75 \%)$ was associated with the smallest number of contested elections (zero to four). When board membership changes, for whatever reason, there is an impact on superintendent turnover. Some (23) superintendents left the district for reasons other than board membership changes, while the majority, $67 \%$ left after there had been one or more changes on the board. When examined by the total number of board turnovers, whether defeated in an election or choosing not to stand for election, the statistical hypothesis that superintendent turnover and board turnover are independent, was rejected ( $p$ $>.02)$. When board turnover was greater than five members, superintendent turnover was 100\%, while at the other end of the distribution, when board turnover was zero or one superintendent turnover was $63 \%$. A more modest turnover rate for superintendents was associated with a board turnover rate of two to four, $34 \%$.

The political climate of the district was studied and, in $62 \%$ of the cases, current superintendents reported that the political climate in their district was "hot" (active, or very active) at the time their predecessor left. A chi-square test of independence was conducted on the relationship between political climate and superintendent 
turnover. The statistical hypothesis that superintendent turnover is independent of political climate was rejected ( $\underline{p}$ $<.01)$. Superintendent turnover was more likely when the political climate is active than when the district is politically calm.

A third factor was examined in superintendent turnover: the superintendent's relationship with the board. A chi-square test of independence was performed on superintendent turnover and opposition to the superintendent by the board. The statistical hypothesis that superintendent turnover and opposition by the board of directors are independent was not rejected ( $p>.05)$. An analysis of political climate, opposition by the board, and superintendent turnover was performed, using a chi-square test of independence. The statistical hypothesis that political climate, opposition by the board, and superintendent turnover are independent was rejected ( $\mathrm{p}<$ .04). When the political climate in the district is active and there is opposition to the superintendent by some members of the board, turnover in the office of the superintendent is likely.

Discriminant analysis of variables and superintendent turnover. Discriminant analysis was used to evaluate whether eight variables from the data gathered on the questionnaire could, in combination, construct a linear discriminant function that would differentiate between 
superintendents who were in jeopardy of losing their positions (turnover) and those who were not in jeopardy (no turnover). The eight variables were: (a) Relationship with the board, (b) Position openings on the board, (c) Percentage ratio of contested elections to board openings, (d) Climate in the district, (e) Contested elections, (f) students in the district, (g) Unsuccessful elections, and (h) Service the number of years on the board. The resulting discriminant function was significant $(\underline{p}<.02)$. The analysis correctly classified $84 \%$ of the superintendents who left their positions and correctly classified $52 \%$ of those who did not leave their positions. Overall, $72 \%$ were correctly classified.

Further analysis revealed that the students, unsuccessful elections, and service variables made minimal contribution to the overall analysis and they were eliminated. When a discriminant function was used to predict superintendent turnover for this group of five variables, it correctly classified $86 \%$ of the superintendents who left their positions and correctly classified $48 \%$ of those who did not leave their positions, with an overall accuracy of $71 \%$.

District size and superintendent/board member turnover. The reporting districts ranged in size from one to 14 schools and from six to 555 teachers. The data were grouped to enable the researcher to perform tests of statistical 
significance. No statistical significance was found between superintendent turnover and district size $(\mathrm{p}>.05)$ or the number of schools $(\mathrm{p}>.05)$. For districts with five-member boards, if relationship between the number of schools or the number of teachers in a district and superintendent turnover exists, it is likely to be small. However, the data were then used in a similar manner to analyze board member turnover. A chi-square test of independence was performed on district size as denoted by the number of schools and board member turnover. The statistical hypothesis that the number of schools and board member turnover are independent was rejected $(p<.04)$. The greater the number of schools in a district, the greater the likelihood of board member turnover. No relationship was found between the number of teachers and board member turnover $(p>.05)$.

Geographic location and superintendent and board member turnover. All of the geographic areas of the state were represented by those districts responding to the questionnaire. Superintendent turnover was analyzed across the state's geographical areas (coast, valley, and eastern). The statistical hypothesis that superintendent turnover and geographic location are independent was not rejected ( $p$ > .05). For districts with five-member boards, any relationship between geographic location and superintendent turnover is likely to be quite small. Geographic location and board member turnover was analyzed in the same manner. 
Again, no statistical significance was discovered $(p>.05)$. Any relationship between geographic location and board member turnover is likely to be quite small.

School type and superintendent and board member

turnover. There are three types of school ldistricts in

oregon: elementary, high school, and union high school

districts. Of the 116 reporting districts; $33 \%$ were

elementary districts, $34 \%$ were high school districts, and $39 \%$ were union high school districts. No grouping of the data was necessary to perform a chi-square test of statistical significance on it. No relationship was discovered between the type of school district and either superintendent $(p>, 05) \mid$ or board $\mid$ member turnover $(p>.05)$.

\section{Conclusions}

This section discusses the conclusions that may be drawn from the analysis of the data gathered in the study pertaining to the longevity of the superintendent and board members. The "interdependence" of superintendents and board members is also discussed.

\section{Longevity of Superintendents}

In the five-year period of this study, the turnover rate for superintendents was $60 \%$; thus, an annual rate of 128 or greater is likely. (This study was/unable to recognize multiple turnovers in a specific district in the five-year period.) This|study did not examine, 
specifically, incumbent defeat and its relationship to superintendent turnover, rather it looked at the total number of board member turnovers whether by defeat or by incumbent choice not to stand for reelection. one can assume that a significant proportion chose not to enter an election in which the chances of reelection were modest or poor. Giles and Giles (1990), Johnson (1988), and Grady (1992) found that the turnover rate for superintendents is higher than average in districts experiencing higher than average board member turnover.

When a district, for whatever reason, experiences too few or too many elections, contested or not, the likelihood of superintendent turnover is greatly increased. Statistical significance was discovered when superintendent turnover was analyzed with too few, too many, and average total elections as variables. When a district had four or fewer contested elections, the superintendent turnover rate was 63\%; and, when a district reported four of fewer elections (contested or uncontested), the superintendent turnover rate was $71 \%$. However, when there was little change (zero or one) in board membership for any reason, the superintendent turnover rate was $63 \%$, with the percentage dropping to $38 \%$ for modest change (two through four). A lower than expected number of contested and uncontested elections could be indicative of the amount of political power that the board is able to wield. The board appears, 
in these districts, able in some way to manipulate the electoral process. It appears that, in these districts, the board has sufficient power and control to summarily dismiss its chief executive officer, whether by "arrangement" or by the non-renewal of his/her contract, and using this power as a "damage control" technique for maintaining its control within the district. At a minimum, it appears that the board holds sufficient political power to ensure levels of discomfort and ineffectiveness on the part of the superintendent that could create a situation/where the superintendent may seek employment outside the district. When a district had five or more contested elections, the superintendent turnover rate was $52 \%$, but, when a district had more than the expected number of elections (nine or more), the superintendent turnover rate was $78 \%$. However, when there were five or more changes of board membership, the superintendent turnover rate/was $100 \%$. A higher than expected number of elections or board changes could indicate a board with little or no political power in its community. Given the high rate of board turnover, it is possible that chance could create a board configuration in which a majority at that time would be opposed to the superintendent. Iannaccone and Lutz (1970) believed that, when board membership changes, the superintendent is associated with the outgoing (old) power structure and that, when enough new members are placed on the board, the new 
board will|replace the superintendent. It is also possible that, since the board has little political power, it might attempt tol appease the community by "offering up a sacrificial lamb," the superintendent. Also, multiple changes on the board result in board members with little experience/ and limited understanding of superintendent/board relations (Chance \& Capps, 1990; Giles \& Giles, 1990; Grady, 1992). In the present study, $47 \%$ of the current superintendents identified knowledge of board/superintendent relationships and board experience as problems.

There appears to be a pattern in superintendent turnover; it is higher in the above and in the below expected ranges. Of the three superintendents who were reported as "fired," one was found to be in a district reporting no contested elections during a five-year period, while the other two were in districts reporting more than five contested elections. All of the 13 superintendents who were reported to be unemployed at the time of the survey came from districts reporting more than five elections.

The average (five through eight) number of elections yields conditions where the superintendent had the greatest amount of stability with a $45 \%$ turnover. Similarly, moderate changes in board membership (two through four) is associated with low superintendent turnover (38\%). This is most likely due to conditions where both the board and the superintendent have sufficient stability and power within 
the community to establish a mutual relationship and to accomplish some meaningful results.

The study revealed three additional variables which could impact superintendent turnover. Those variables are: the superintendent's relationship with the board, the amount of opposition to the superintendent has to within the board, and the political climate in the district. There were two measurements of superintendent relations with the board; neither was clearly related to superintendent turnover. When the data were analyzed concerning the relationship that the superintendent had with the board alone, no significance was revealed. In like manner, when data concerning the amount of opposition on the board to the superintendent and superintendent turnover was analyzed (including the "fired" category) no significance was found. When data concerning the political climate in the district was analyzed with superintendent turnover, significance was disclosed. This result could be expected as there is little doubt concerning the political nature of the superintendency (Blumberg, 1989; Hess, 1986). What is interesting however, is that the relationship and/or opposition by the board to the superintendent is not significant until political climate is considered. When superintendent turnover was analyzed with either board relation or board opposition, no significance was disclosed; however, when those same analyses were conducted with political climate as an additional variable, 
significance was disclosed in both cases. The superintendent's relationship/opposition by the board is not critical to the longevity of the superintendent so long as the climate in the district remains calm. Studies have shown that superintendent tend to leave the district when relations with the board deteriorate or the superintendent is opposed by members of the board (Caldwell \& Sites, 1983). However, this study did not find that superintendent relations with, or opposition from the board impacted superintendents until the political factor was introduced. When the political climate was active, board relations and/or opposition affected superintendent turnover.

\section{Board Member Longevity}

The longevity of board members is relatively short, little more than one term $(5.2$ years). There were two major causes for this limited longevity: (a) They were defeated at the polls (i.e., 64\% of incumbents were defeated) or (b) They chose not to run for reelection (25\%). Although confidence in the mean value for board member longevity is limited as a result of depending on the perception of current superintendents, it may be viewed as indicating a relatively short tenure; the $61 \%$ turnover rate supports this view.

Political climate, alone, did not significantly impact board member turnover although it should be understood that the more active the political climate in a district, the 
more likely that there would be an election either contested or non-contested. The relationship of the board to the superintendent and the opposition by the board to the superintendent (individually)had no significant impact on board member turnover. However, as with superintendent turnover, when the political climate in the district "heated up," both the board's relationship and/or their opposition to the superintendent became significant factors in board member turnover. This finding agrees with the work of Iannaccone and Lutz (1970) and Lutz and Iannaccone (1987) who found that as school boards become" what the community perceives as, unresponsive, incumbent board members are defeated and superintendents replaced.

Significance was discovered when the size of the district (as measured by the number of schools in the district) was analyzed with board member turnover. Greater turnover of board members occurs in districts with more schools than in districts with fewer schools, but surprisingly this was not related to the number of teachers. Although the study did not disclose a cause for this phenomena, it is suspected that, the greater the number of schools, the greater the possibility of conflict between the patrons of the individual schools. This in turn could create instability within the district.

\section{Interdependence}

Webster's defined a symbionic relationship as follows: 
Living together in more or less intimate association or even close union of two dissimilar organisms in any of various mutually beneficial relationships. Mutual cooperation between persons and groups in society. (Grove, 1976, p. 2,316)

Certainly such a relationship exists between board members and their superintendent. When boards and superintendents do not agree and the political climate becomes active in the district, both board members and superintendents tend to lose their positions. When boards and chief executive officers allow the political climate in the district to become active, there are more elections, more defeats, and more turnovers in both the superintendency and on the board. There is a close relationship between the success of board members and of superintendents; if either is unsuccessful, the climate in the district may become active, creating a situation where both parties are in jeopardy of losing their positions.

A number of factors impact community stability. Johnson (1988) found that changes in community values influence board values, while Lutz and Iannaccone (1978) found that politics in a district are dominated by economic values. This study found that recognizing stability in a community may be easier than attempting to discover causes for instability. A stable community appears to be one in which board turnover, from whatever cause, falls within the expected range of two to four changes in a five-year period. 


\section{Recommendations for Further Research}

The research revealed statistical significance between the size of a district, as denoted by the number of schools in the district, and board turnover. Grady (1992) held that the cause for this is the use by board members of their election to the board as a stepping stone to higher political office. However, in this study, the number of teachers in a district was not related to board member turnover. This somewhat contradicts Grady's interpretations, at least as applied to oregon districts with five-member boards. This appears to be an area where further research is needed. If board membership in larger districts is an initial step in establishing a political career then it appears that the decisions reached by those boards may be more political than educational in nature. There may be greater opportunity in these situations for "political posturing." However, it may be that more schools create more political units which could de-stabilize the district.

The Oregon election law requires annual board elections. There is a good possibility that this law will be changed by the 1995 legislature. The legislature is exploring the possibility of changing the law to require bi-annual elections of the board. The study showed that when elections, either contested or not, exceeded the 
expected of five to eight elections, the possibility of superintendent turnover increased. As a result of this change, appointees could legally be expected to serve longer terms thereby reducing the total number of elections. Since boards tend to appoint members who hold views similar to their own, board member and superintendent stability should be enhanced. What will happen should the expected number of elections decrease?

Although there are legal requirements in oregon for board elections, it appears that some boards (those with zero to two elections in a five-year period) have manipulated the system in some way. The consolidation of elementary districts with high school districts only partially accounts for these low numbers of elections. There are too many districts reporting too few elections for this to result from consolidation alone. Other reasons could be attempts by boards to retain "good" members or that there is little interest in the community in being on the board. The increase in superintendent turnover, in districts with fewer than the expected number of elections, suggests that there is a deliberate attempt by some boards to control the political environment. An in-depth study of this phenomena may be in order. Political climate in the district impacted superintendent turnover. However, when the climate was described as "very active" there were fewer turnovers in the 
superintendency than when the climate was described as just "active." This may be due, in part, to a "drawing together" of the board and superintendent in times of crises under the leadership of the board chair. This in itself is worthy of further study.

Giles and Giles (1990) found that board/superintendent disharmony was the major cause of superintendent turnover in California from 1986 to 1989 . It is generally accepted that the chairman of the board exhibits a leadership role. It would be advantageous, therefore, to study the relationship between the superintendent and the board chairman. Does the chair have significantly more political power than other members of the board? If so, can this power impact the longevity of the chief executive officer? could a difference in the perceived roles of the two positions cause sufficient conflict to create a situation where one or both leave their position in the district?

What constitutes a "contested election?" This study examined contested elections and superintendent turnover, but it did not ask how many candidates there were for each open position. It is logical to assume that political interest would be increased in some proportion to the number of candidates for each opening. Inversely, is there significance in those situations where only one candidate stands in opposition to the incumbent? In this case, the community could realize that a "special" candidate is needed 
to defeat the incumbent and manipulate the process to allow for the "best" candidate to run unopposed by others. Either case could impact superintendent longevity. A study of contested elections is needed to identify the various configurations of these elections and how each may impact superintendent turnover.

Many districts employ a chief executive officer who also holds another position in the district. This is most apparent in the superintendent/principal positions held in smaller school districts. The building principal works directly with students and their parents. The building principal is able to build a relationship with these patrons that may differ from the relationship a superintendent is able to establish with patrons. A study of the longevity of split position superintendents' turnover comparative to that of the turnover for superintendents who have a single position in the district is needed. 


\section{REFERENCES}

Ackerly, R. L., \& Gluckman, I. B. (1976). The reasonable exercise of authority. Reston, VA: National Association of Secondary School Principals.

Anderson, G. J. , \& Lairwers, J. A. (1978). Institutional leadership for educational reform: The Atlantic Institute of Education. Paris: UNESCO.

Appleton, N. (1983). Cultural pluralism in education. New York: Longman Inc.

Arnez, N. L. (1981). The besieged school superintendent. Washington, DC: National Association of Secondary School Principals.

Bair, F. H. (1934). The social understanding of the superintendent of schools. New York: Columbia University.

Barraclough, T. (Ed.). (1974). Employment contacts for school administrators. Reston, VA: National Association of Secondary School Principals.

Beaumont, J. J. (1993). Factors contributing to involuntary superintendency turnover in urban school systems (Doctoral dissertation, University of Baltimore, 1993). Dissertation Abstracts International, 54, 11A.

Bender, R. (1969). The politics of schools. New York: Harper/Row.

Bennett, D. A. (1991). Big city blues. American School Board Journal, 177(10), 31-33.

Blumberg, A. (1989). School administration as a craft. Baltimore: Allyn and Bacon.

Blumberg, A., \& Blumberg, P. (1985). The school superintendent: Living with conflict. New York: Columbia University.

Bolton, D. L. (1980). Evaluating administrative personnel in school systems. New York: Teachers College. 
Brown, S. I. (1991, January). Educational Finance equity: Recent developments in state courts. National Association of Secondary School Principals Bulletin, $\underline{75}(531), 35-36$.

Bryant, M. T., \& Grady, M. P. (1991, March). When boards cross the line. American school Board Journal, $177(10), 20-21$.

California Proposition 13, Constitution of the state of California Article 13 B, 1973.

Caldwell, W. E., \& Sites, W. H. (1983, April 14). The relationship between high labor: Management conflict and turnover of key school district personnel. Paper presented at the annual meeting of the American Educational Research Association, Montreal, Quebec.

Campbel1, R. F., Cunningham, L. L., \& McPhee, R. F. (1965). The organization and control of American schools. Columbus, OH: Merrill Books.

Chance, E. W., \& Capps, J. L. (1990). Administrator stability in rural schools: The school board factor. (Doctoral dissertation, University of oklahoma, 1990). Dissertation Abstracts International, $\underline{52}$, 05A.

Chand, K. (1984). Board relationships in the United States and Alaska. (Doctoral dissertation, University of Alaska, 1984). Dissertation Abstracts International, $\underline{46}, 03 \mathrm{~B}$.

Chion-Kenney, L. (1994, February) . Search consultants. The School Administrator, $51(2), 8$.

Cistone, P. J. (1978, June). School board members learn their skills before they become board members. American School Board Journal, $165(6), 4$.

Colorado Association of School Executives. (1982). Administrator evaluation, reassianment, non-renewal, demotion, and dismissal: Guidelines for a fair process. Denver: Author.

Conway, J. A., Jennings, R. E., \& Milstein, M. M. (1974). Understanding communities. Englewood cliffs, NJ: Prentice-Hall.

Copeland, M. E. (1993). A descriptive study of superintendent stability in rural oklahoma schools. (Doctoral dissertation, University of Oklahoma, 1993). Dissertation Abstracts International, 54, $11 \mathrm{~A}$. 
Crook, D. R., \& Lafleur, K. N. (1975). Educational research. Boston: Allyn and Bacon.

Deary, J. J. (1989). Decision making and superintenclent turnover: An empirical test (Doctoral dissertation, University of Bridgeport, 1989). Dissertation Abstracts International, 50, $08 \mathrm{~A}$.

Doob, H. (1974). Tenure and contracts for administrators, educational research services report. Arlington, VA: Educational Research Services.

Downey, G., Bushweller, K., \& Zakariya, S. (1994, December). Leadership. American School Board Journal, 181(12), A1-A31.

Ferrone, K. T. (1988). Relationship among superintendents and board members (Doctoral dissertation, Kent state University, 1988). Dissertation Abstracts International, 51, 04A.

Finnie, R. A. Jr., \& Sniffin, P. B. (1984) . Good endings: Managing employee terminations. Washington, DC: College and University Personnel Association.

Firestone, W. A. (1980). Great expectations for smal1 schools. New York: Praeger.

Flanning, K. L. (1989). An analysis of those factors which influence the selection and appointment of superintendents of education in the state of Alabama (Doctoral dissertation, University of Alabama, 1989). Dissertation Abstracts International, 50, 04A.

Ford, T. R. \& DeJong, G. F. (1970). Population growth and educational development. Englewood Cliffs, NJ: prentice Hall.

Fuller, S., \& Martin, G. (1991, January). Nine ways to build better relations with your board. The Executive Educator, 13(1), 22-23, 28 .

George, P. S. (1987, April). Performance management in education. Educational Leadership, 44(7), 32-40.

Giles, S., \& Giles D. E. (1990). Superintendent turnover: Crisis facing California school districts (Doctoral dissertation, University of California, 1990). Dissertation Abstracts International, 51, $11 \mathrm{~A}$. 
Grady, M. L. (1992). A rural school district in decay. (Doctoral dissertation, University of Nebraska, 1992). Dissertation Abstracts|International, 53, 04A.

Greenwood, S. C., Zirkel,|P. A. (1990, October). Superintendent dismissals: Know your rights and avoid wrongs. School Administrator, 47(9), 30-31.

Grove, P. G. (Ed.), (1976). Webster's new international dictionary (3rd ed.). Springfield, MA: Webster.

Harris, N. F. (1977). Recruiting and selecting a superintendent as viewed by a school board president. Arlington, VA" Educational Research Service.

Haughland, M. (1987). A comparative analysis of the professional competencies needed by superintendents of public schools perceived to be most desirable for successful employment by school board members and superintendents in South Dakota. (Doctoral dissertation, University of South Dakota, 1987). Dissertation Abstracts International, 47, 05A.

Heim, J. M. , \& Wilson, A. P. (1987). Situational factors contributing to administrative turnover in small Kansas school districts and high schools (Doctoral dissertation, University of Kansas, 1987). Dissertation Abstracts International, 48, 04A.

Heller, R. W., Woodworth, B. E., Jacobson, S. L., \& Conway, J. A. (1991, March). Disaster, controversy--Are you prepared for the worst? Executive Educator, 13(3), 20-23.

Hess, F. (1986, May). Part II: Dismissal and renewal for fired executives. The School Administrator, 43 (5), 18-19.

Hoseman, C. M. (1990, October). Superintendents selection and dismissal: A changing community defines its values. Urban Education, 25(3).

Iannaccone, L., \& Lutz, F. W. (1970). Politics, power, and policy the governing of local school districts.

Albany, $\mathrm{OH}$ : Charles Merrill.

Johnson, D. (1988) . A case study of Lacy Rivers School

District (Doctoral dissertation, University of Washington, 1988). Dissertation Abstracts International, 50, $11 \mathrm{~A}$, 
Jones, C. O. (1984). An introduction to the study of public policy. Monterey, CA: Brooks/Cole.

Jones, G. D. (1990, November). Don't ignore the college candidate. The American School Board Journal, 177(11), 34-35.

Keisling, P. (1993). Oregon blue book. Salem: Oregon state Printing.

Kenneth, R. (1991). Indiana superintendent evaluation: The effects of demographics and critical issues on the importance of areas of responsibility and specific evaluation criteria (Doctoral dissertation, Indiana University, 1991). Dissertation Abstracts International, 51, 04A.

Krajewski, R. (1982). The anguish of losing a superintendency. American School Board Journal, $169(2), 28-30$.

Lewis, A. (1989). Restructuring America's schools. Arlington, VA: American Association of School Administrators.

Lewis, A. (1993). Leadership styles. Arlington: American Association of School Administrators.

Loomjs, C. P. (1960). Social systems. Princeton: Nostrad Company.

Looney, G. E. (1990). The strategy of school superintendents: A political analysis (Doctoral dissertation, West Virginia University, 1988). Dissertation Abstracts International, 50, $11 \mathrm{~A}$.

Lordon, J. K. (1991). A case study of conflict management in superintendent-school board relationships (Doctoral dissertation, University of Pittsburgh, 1991). Dissertation Abstracts International, 52, 05A.

Lutz, F. W. (1992). A kinder gentler world. Journal of Rural and Small Schools, $\underline{5}(2), 48-55$.

Lutz, F. W., \& Iannaccone, L. (1978) . Public participation in local school districts: The dissatisfaction theory of democracy. Columbus, OH: Charles Merrill.

Lyman, L. L. (1990). Factors and issues affecting board of education decisions: A case study (Doctoral dissertation, University of Nebraska. 1990). Dissertation Abstracts International, 51, $11 \mathrm{~A}$. 
McCarthy, D. J., \& Ramsey, C. E. (1971). The school managers. Westport, CT: Greenwood.

McCarthy, M. M. , \& Cambron-McCabe, N. H. (1981). Public school law (2nd ed.). Boston: Allyn and Bacon Inc.

Ogle, L. T. (Ed.). (1990). The condition of education 1990. Washington, DC: U.S. Department of Education.

Oregon Ballot Measure \#5 (1990).

Oregon Department of Education. (1989). oregon laws related to public schools and community colleges. Salem: Author.

Oregon Department of Education. (1991). Oregon laws relating to public schools and community colleges. Salem: Author.

Oregon Department of Education. (1994). Oregon school directory, 1993-1994. Salem, OR: Author.

Oregon Educational Act for the 21st Century (1991).

Paynter, D. H. (1980). Must our schools die? Portland, OR: Multnomah Press.

Perry, C. M. , \& Perry, T. H. (1991). What administrators of smaller schools do. National Association of Secondary School Administrators Bulletin, $\underline{75}(533), 18$.

Peterson, M. W., \& Corcoran, M. (1985). Institutional research in transition. San Francisco: Jossey-Bass.

Poyourow-Ripple, R. (1990). A descriptive survey of school board member turnover and superintendent turnover in Pennsylvania, 1973-1987 (Doctoral dissertation, Temple University, 1990). Dissertation Abstracts International, 51, 03A.

Renchler, R. (1992, Winter). Urban superintendents turnover: The need for stability. Urban Superintendents sounding Board, $1(1), 6$.

Rist, M. C. (1990, December). Big city survival traits. The Executive Educator, 176(9) 20-24, 39 .

Rogers, J. J. (1990, November). Building a better school board. The American School Board Journal, 177(11), 23-25. 
Rohner, J. J/. (1991) . Superintendent job tasks (Doctoral dissertation, University of Missouri, 1991). Dissertation Abstracts International, 50, $11 \mathrm{~A}$.

Schmuck, P. A., \& Schmuck, R. A. (1990, July). on the road. The American School Board Journal, 177(7), 30 .

Smith, L. M.l, Dwyer, D. C., Prunty, J. J., \& Kleine, P. F. (1988). Innovation and change in schools: History, politics, and agency. New York: Falmer Press.

Staff. (1990, November). What does a rural school superintendent really do? The School Administrator, 47(11), 29 .

Staff. (1991, January 10). Population growth in county. Hillsboro Argus, p. 1 .

stettler, L.|M. (1991). Freedom to lead (Doctoral dissertation, Miami University, 1991). Dissertation Abstracts International, 52, 04A.

stover, D. (1990, November). Calling it quits. The American School Board Journal, 176(11), 29-31.

Stufflebeam, D. L. (1994, December). The troubled state of superintendent performance evaluations. The school Administrator, 51(11), 18-23.

Sullivan, P. M. (1990). The relationship between incumbent school board member replacement and superintendent turnover for selected South Carolina school districts from 1978-1988 (Doctoral dissertation, University of Georgia, 1990). Dissertation Abstracts International, 52, 01A.

Theisen, W. W. (1971). The city superintendent and the board of education. Unpublished master's thesis, Columbia University, New York.

Thompson, D.|C. (1990, June). School finance and the courts: A reanalysis of progress. West's Educational Law Reporter, $\underline{59}(4), 945$.

Trotter, A. (1990, December). Flagrant delicto. The American School Board Journal, 177(12), 12-14.

Tuttle, E. M. (1963) . School board leadership in America. Danville, IL: The Interstate. 
Vail, J. F. (1991). Leadership styles an personality types of superintendents in South Carolina (Doctoral dissertation, University of South Carolina, 1991). Dissertation Abstracts International, 52, $01 \mathrm{~A}$.

Walden, J. C. (1966). School board changes and involuntary superintendent turnover. Unpublished doctoral dissertation, claremont University, Ann Arbor, Michigan.

Washington County Department of Land Use and Transportation. (1990, December). Demographic changes: Future growth presentation. Presentation to Washington County Superintendents, Hillsboro, OR.

Washington County Department of Land Use and Transportation. (1993). Future Growth Presentation Packet. Hillsboro, OR: Author.

Weller, D. L. (1991). Superintendent turnover and school board member defeat. Journal of Educational Administration, 29(2), 52 .

Wilson, A. R., \& Heim, J. M. (1984). Turnover of rural Kansas school superintendents from 1978-1984. (Doctoral dissertation, University of Kansas, 1984). Dissertation Abstracts International, 48, 04A.

wilson, w. (1887, June). The study of administration. Political Science Quarterly II.

Wood, F. E. (1990). What makes a successful superintendent school board relationship (Doctoral dissertation, Colombia Teachers' College, 1990). Dissertation Abstracts International, $51,3 \mathrm{~A}$.

Yock, C. M. (1989). Superintendent turnover: A national survey of the perceptions and expectations of school board members (Doctoral dissertation, Virginia Polytechnic Institute and Virginia state University, 1989). Dissertation Abstracts International, 50, 11A.

Zakariya, S. B. (1984). If you ax the superintendent, don't chop off your vital options. American School Board Journal, 171(11), 23-27.

Zeigler, H., Kehoe, E., \& Reisman, J. (1985) . City managers and superintendents: Response to community conflict. New York: Praeger. 
APPENDIX A

QUESTIONNAIRE SENT TO ALL DISTRICTS GOVERNED BY FIVE-MEMBER SCHOOL BOARDS 
1. When did you become superintendent (date)?

2. What was your previous position?

3. On what date did your predecessor leave his / her position?

4. Was there an interim superintendent?

QUESTIONS \#5 THROUGH \#9 APPLY TO YOUR PREDECESSOR EXCLUDING ANY INTERIM SUPERINTENDENTS

5. Your predecessor left this position because (Check all that apply)

A. Resigned Accepted a comparable position. Accepted a better position. Accepted a lesser position. Left education Is not employed at present.

B. Retired Met PERS requirements. Did not meet PERS requirements. As part of an arrangement with the Board.

C. Other Wasinon-renewed. Medical reasons. Contract bought by Board.

6. Did the District attempl: a bond issue during the final two years of your predecessor's service?

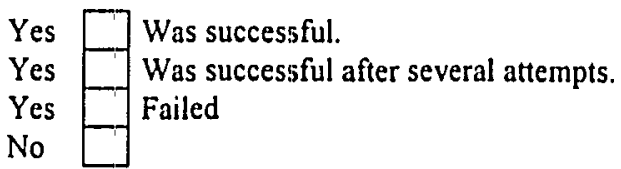

7. What was the political climate in the district at the time your predecessor left? (Check only one)

The political climate in the district was calm.

There was some political activity relevant to the district.

The district was active in politics relating to it. 
8. What was your predecessor's relationship to the Board at the time your predecessor left? (Check all that apply)

Opposed by a minority of the Board. Opposed by a majority of the Board Dismissed through Board action. In good standing with the Board.

9. How would you characterize your predecessor's relation with the board?

Excellent. Board was confident in the superintendent.

Good. The Board was mostly supportive.

Poor. The Board was involved in the daily operation of the schools.

Bad. Little support for the superintendent, the Board involved in schools.

\section{QUESTIONS \#10 THROUGH \#13 APPLY TO BOARD MEMBERS.}

10. How many Board positions were open, both incumbent and non-incumbent, for election during the last five years?

11. Of those positions in $\# 10$ above, how many were contested?

12. Directions: Please check all that apply for each board member who faced, or could have faced, reelection during the five years preceding this date. Add columns as needed. Please remember that the data pertains to incumbent board members only.

\section{A. Stood for reelection}

\begin{tabular}{|l|l|l|l|l|l|l|l|l|l|l|}
\hline & A & B & C & D & E & F & G & H & I & J \\
\hline Was elected & & & & & & & & & & \\
\hline Was defeated & & & & & & & & & & \\
\hline
\end{tabular}

\section{B. Nature of Election}

\begin{tabular}{|l|l|l|l|l|l|l|l|l|l|l|}
\cline { 2 - 9 } \multicolumn{1}{c|}{} & A & B & C & D & E & F & G & H & I & J \\
\hline $\begin{array}{l}\text { Opposed not } \\
\text { contested }\end{array}$ & & & & & & & & & & \\
\hline Opposed \& contested & & & & & & & & & & \\
\hline
\end{tabular}




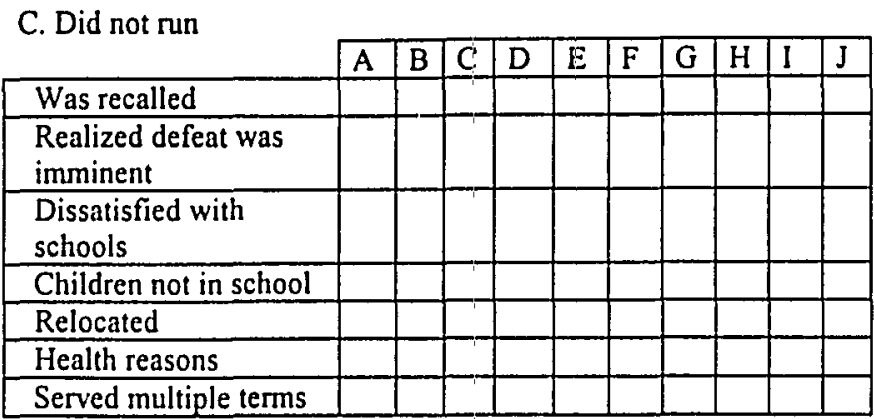

13. What is the average length of service for all members of the Board who have served during the past five years? (Round up to the nearest year)

14. Has Ballot Measure \#5 impacted the functioning of the Board, superintendent, and / or the Board - superintendent relationship? If 'yes,' please explain.

15. What do you feel is the biggest problem in your district at present?

16. What causes you the greatest difficulty in dealing with your Board?

17. Are you satisfied with your current position? 
Please feel free to comment below. Use the reverse side of this sheet or additional pages as necessary.

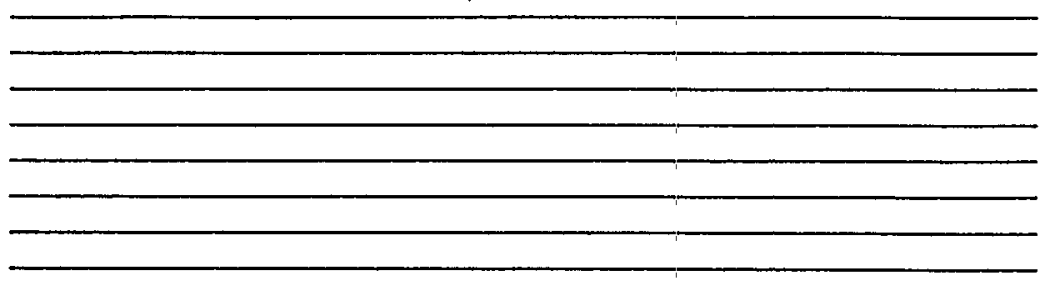


APPENDIX B

\section{LETTERS OF SUPPORT}


November 1993

CONFEDEAATION OF OREGON SCHOOL

Sulte 100 $20713 \operatorname{tin}$ SI. S.E. (503) 581.3141
OREGON SCHOOL BOARDS ASSOCIATION

P.O. $80 \times 1060$ Salam, OR 97308 1201 Coun S1. N.E. $5010 \mathrm{~m}$, OR 97301
(503) $580-2800$
Dear Superintendent:

Al1 of us are aware of the many challenges facing you as administrators today; limited funding under Measure \#5, collective bargaining, special interest groups, complex student needs, mandated programs, and community politics. These challenges individually and collectively make your role as a school superintendent both interesting and increasingly difficult.

Your success in dealing with the challenges facing the school superintendent is, to a large degree, dependent upon your relationship with your school board. Fred Loomis, superintendent, Gaston is conducting a study of some aspects of superintendent-board relationships as part of his doctorate program at Portland state.

We encourage you to complete and return the attached questionnaire' to assist Fred with'his study. We believe the results of the study will be valuable to current and future superintendents.

Sincerely,

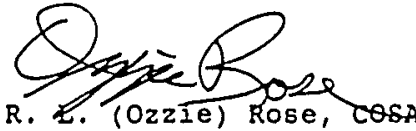
Executive Director

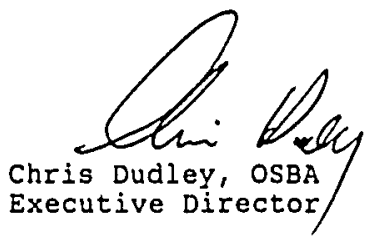

$\mathrm{OR} / \mathrm{jd}$

Enclosure 
November 1993

CONFEDERATION OF OREGON SCHOOL ADMINISTRATORS

Sulte 100

70713 th St. S.E.

(503) 581.3141
Dear Superintendent:

All of us are aware of the many challenges facing you as administrators today; limited funding under Measure \#5, collective bargaining, special interest groups, complex student needs, mandated programs, and community politics. These challenges individually and collectively make your role as a school superintendent both interesting and increasingly difficult.

Your success in dealing with the challenges facing the school superintendent is, to a large degree, dependent upon your relationship with your school board. Fred Loomis, superintendent, Gaston is conducting a study of some aspects of superintendent-board relationships as part of his doctorate program at portland state.

We encourage you to complete and return the attached questionnaire' to assist Fred with his study. We believe the results of the study will be valuable to current and future superintendents.

Sincerely,
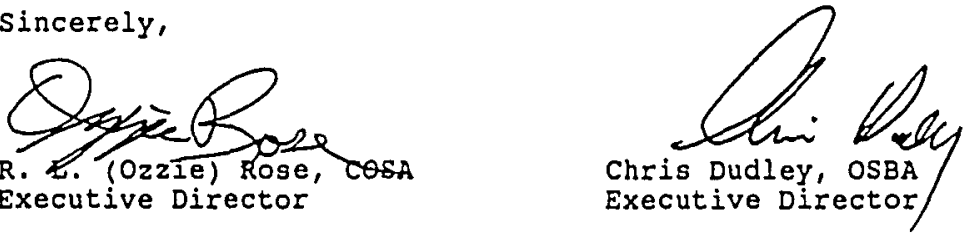

OR/jd

Enclosure

P. $80 \times 1068$

Salom, OA 97300

S.1. Coun

(50) $580-2800$ 


\section{APPENDIX C \\ LIST OF DISTRICTS GOVERNED BY FIVE-}

MEMBER SCHOOL BOARDS 
NAME Of DISTRICT

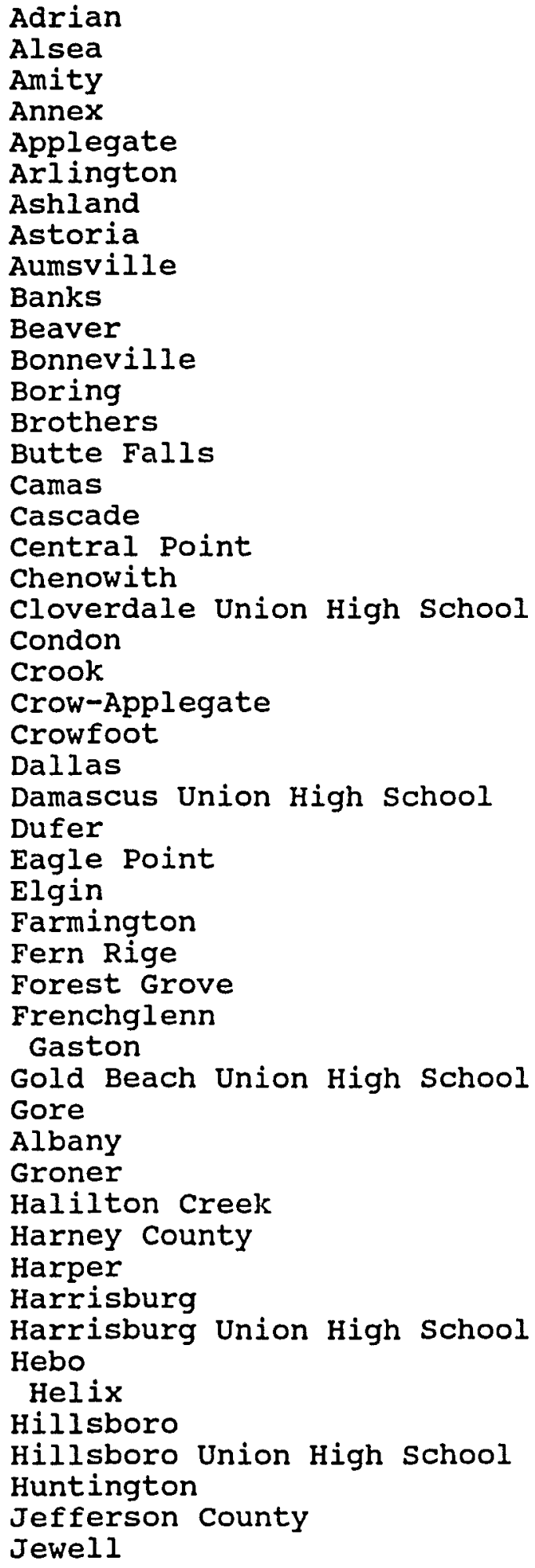

\section{BUPERINTENDENT}

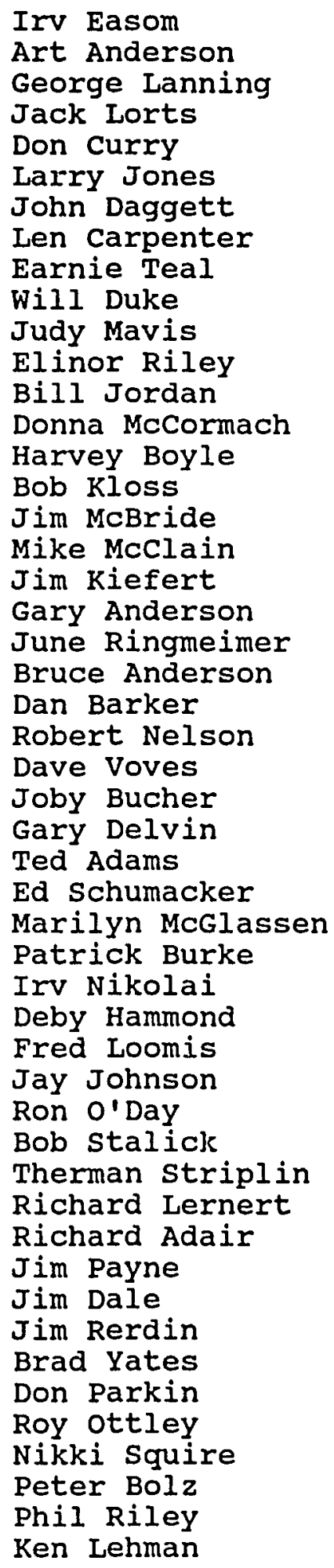


Jordan Valley

Josephine county

Klamath county

Klamath Falls

Lake Oswego

Lakeview

Lebanon

Lincoln county

Markola

Maupin

McDermitt

Mcloughlin

Mill City

Mitchell

Molalla River

Mt. Angel

Nestucca

North Douglas

North Lake

North Plains

North Powder

Oakland

Oakridge

olney

ontario

oregon City

orient

Paisley

Parkrose

Perrydale

Petersberg

Philomath

Powers

Redmond

Reedville

Riverdale

Sandy Union High School

Sauvie Island

Scio

Scotts Mills

Sheridan

Sherman Union High School

Sherwood

Silverton

Sisters

Sodaville

South. Sherman

Springfield

stanfield

sublimity

Suthrlin

The Dalles
Jack Crippen

Carole Ricotta

Frank Ellis

Ray Crawford

Bill Korach

Howard ottman

Ike Launstein

Skip Liebertz

Ross Bradford

Howard Fetz

Tammara Fretwell

Ron Hackbarth

John Campbell

Mike Carroll

John Rogers

Toni Hardman

Walt Wilson

Ottis Falls

Mike Costello

Bob Duffy

NOT DESIGNATED

Linda Burton

Mike Keown

Marilyn Pheasant

David Cloud

Don Tank

Tom Greene

Dan Thomas

Jacki cottingim

Tim Adgit

Howard Betz

Chuck Jackson

Les Fettig

Elton Gregory

Dave Gillespie

Lee Wickland

Dennis Crow

Ken Tessen

John Rullofson

David Mikkelson

Leroy Key

Rick Eggers

Bill Hill

Graig Roessler

Judy May

NOT DESIGNATED

Keith Dell

Paul Plath

Harvey Hazen

Barry Gourley

Richard Smith

Ivan Hernandez 
Tigard-Tualatin

Tillamook

Umpqua

Victor Point

willowa

Wasco Union High School

West Linn

W. Union

Willamina

winston

Woodburn

Yamhill Union High School

Yoncolla
Russ Joki

Elaine Hopson

Jan Schock

Robert Humphreys

Edward Jensen

Ray Hanson

Roger Woehl

Cliff Tetreault

Larry Audet

Jim Burton

Keith Robinson

Nolan Ferguson

Ken Sprute 